Universidade de São Paulo

Faculdade de Educação

FLAVIA MARIA DE VASCONCELLOS

"NÃO SEI AINDA, POSSO PENSAR?":

UM ESTUDO SOBRE OS IMPASSES ESCOLARES

COMO UM SINTOMA SOCIAL

São Paulo

2012 
FLAVIA MARIA DE VASCONCELLOS

\title{
"NÃO SEI AINDA, POSSO PENSAR?": UM ESTUDO SOBRE OS IMPASSES ESCOLARES COMO UM SINTOMA SOCIAL
}

\author{
Dissertação apresentada ao Programa \\ de Pós-Graduação da Faculdade de Educação \\ da Universidade de São Paulo, \\ para obtenção do título de Mestre em Educação. \\ Área de Concentração: \\ Psicologia e Educação \\ Orientador: Prof. Dr. Rinaldo Voltolini
}


Autorizo a reprodução e divulgação total ou parcial deste trabalho, por qualquer meio convencional ou eletrônico, para fins de estudo e pesquisa, desde que citada a fonte.

Catalogação na Publicação

Serviço de Biblioteca e Documentação

Faculdade de Educação da Universidade de São Paulo

$37.046 \quad$ Vasconcellos, Flavia Maria de

V331n "Não sei ainda, posso pensar?" : um estudo sobre os impasses escolares como um sintoma social / Flavia Maria de Vasconcellos ; orientação Rinaldo Voltolini. São Paulo : s.n., 2012.

$113 \mathrm{p}$.

Dissertação (Mestrado - Programa de Pós-Graduação em Educação. Área de Concentração : Psicologia e Educação) - - Faculdade de Educação da Universidade de São Paulo.

1. Educação 2. Psicanalise 3. Psicanálise - Cultura 4. Impasse Educação 5.Instituições I. Voltolini, Rinaldo, orient. 
"NÃO SEI AINDA, POSSO PENSAR?":

UM ESTUDO SOBRE OS IMPASSES ESCOLARES

COMO UM SINTOMA SOCIAL

Dissertação apresentada ao Programa de Pós-

Graduação da Faculdade de Educação da Universidade de São Paulo, para obtenção do título de Mestre em Educação. Área de Concentração: Psicologia e Educação

Aprovada em:

Banca Examinadora

Prof. Dr.: Instituição:

Julgamento: Assinatura:

Prof. Dr.: Instituição:

Julgamento: Assinatura:

Prof. Dr. RinaldoVoltolini:

FEUSP (orientador) 


\section{O apanhador de desperdícios}

Uso a palavra para compor meus silêncios.

Não gosto das palavras

fatigadas de informar.

Dou mais respeito às que vivem de barriga no chão

tipo água pedra sapo.

Entendo bem o sotaque das águas.

Dou respeito às coisas desimportantes

e aos seres desimportantes.

Prezo insetos mais que aviões.

Prezo a velocidade

das tartarugas mais que a dos mísseis.

Tenho em mim esse atraso de nascença.

$\mathrm{Eu}$ fui aparelhado

para gostar de passarinhos.

Tenho abundância de ser feliz por isso.

Meu quintal é maior do que o mundo.

Sou um apanhador de desperdícios:

Amo os restos

como as boas moscas.

Queria que a minha voz tivesse um formato de canto.

Porque eu não sou da informática:

eu sou da invencionática.

Só uso a palavra para compor meus silêncios.

(Manoel de Barros) 
Para Tom, improviso e divertimento

Para João Antônio, o inventor!!, que me lembra da importância de brincar Para Marininha, que não me deixa ficar séria demais 


\section{Agradecimentos}

Ao meu orientador Rinaldo Voltolini, pela generosidade em sua transmissão, pelo acompanhamento acurado e decisivo deste trabalho, pelo incentivo e pelo apoio;

À Maria Cristina Kupfer, Lina Galletti Martins de Oliveira (in memorian) e Marize Lucila Guglielmetti, com quem aprendi que uma instituição é lugar de vida, de invenções e de encontros valiosos;

Ao Leandro de Lajonquière, primeiro leitor de meus escritos sobre o Trapézio, pelos seus comentários e incentivo;

À Carmen Molloy, pela escuta generosa e atenta, e pelos seus comentários preciosos;

Ao Contardo Calligaris, pelo silêncio que me acompanha;

À Isabel Moreira Ferreira, que, no melhor sentido desses termos, apoiou a minha irresponsabilidade e inconsequencia quando fundamos o Trapézio, pelo compartilhar de um sonho, pela cumplicidade, ao longo de tantos anos, na difícil, mas instigante, condução e sustentação de um trabalho institucional;

À Renata Dabori, amiga querida, madrinha e colega, com quem compartilhei os primeiros esboços de um sonho que veio a se tornar realidade;

À Simone Kubric, amiga, colega, leitora atenta de meus escritos, e parceira no amor pelos estudos, pelo debate e pela transmissão;

À Sabrina Veloso, amiga sabida e parceira preciosa, que não me deixa esquecer de me divertir;

À Alessandra Affortunati Martins Parente, pela leitura que me fez não me sentir tão só;

Ao Silmar Gannam, que faz da clínica pediátrica, uma clínica de cuidado e de entusiasmo; pela amizade e pelo carinho que me deram apoio fundamental no momento da qualificação;

À Janaína Venezian e Rosana Amá Brusco, que me ensinaram um pouco mais sobre o amor pelas palavras;

À Renata Petri, amiga querida, que está longe, mas está perto, a quem admiro muito e com quem aprendo que a clínica é um lugar muito complexo, para ser simples;

À Deborah Bubarelli Valentini, com sua postura séria e divertida, capaz de tornar mais leves as pedras do meio do caminho;

Ao "grupo da tarde", e às nossas reuniões de quinta-feira (que se eternizaram!!!!), Carolina Bacchi, João França e Renata Dabori; 
À primeira "equipe" do Trapézio, que acreditou e sustentou, ao longo de 4 anos, uma experiência que ainda nem tinha nome: Carolina Bacchi, Daniela Hanff , Isabel Moreira Ferreira, Rita Paula Cardoso e Renata Dabori;

À todas as minhas parceiras no Centro de Estudos do Trapézio: Ana Lícia Pegorelli, Christiane Laurito Costa, Sabrina Veloso e Simone Kubric.

A todas as minhas "duplas de coordenação" nas oficinas do Trapézio, que improvisaram junto comigo no imprevisto dos acontecimentos, e com quem tive(tenho) o prazer de compartilhar in loco as preciosidades da clínica: Ana Lícia Pegorelli, Flavia Fló, Isabel Rezende, Janaína Venezian, Mariângela Pacchi, Renata Dabori, Rosana Amá Brusco;

A todos os "trapezistas", que com curiosidade e respeito se aproximaram da invenção que é o Trapézio, e que nos ajuada(ra)m a continuar inventando: Adriana Barbosa, Adriana Dias, Adriana Castro, Adriana Mitiko, Alessandra Affortunati Martins Parente, Alice Turazzi, Amanda Viana, Ana Galletti Martins de Oliveira, Ana Lícia Pegorelli, Ana Paula, Ana Paula Faulhaber, Andrea Gomes, Bartira Bianchini, Christiane Laurito Costa, Ciça Kfouri, Daniella Teixeira Souza, Eliana Azevedo, Flavia Fló, Flávia Ribeiro, Ilana Katz Zagury Fragelli, Isabel Rezende, Janaína Venezian, Janaína Klinko, Juliana Glasberg, Juliana Venezian, Juliana Vidigal, Laís Fontenelle, Letu, Lígia Cortelazzi Garcia, Lia Rudge, Luciana Netto, Mariana da Gama e Silva, Mariângela Pacchi, Miguel Vallim, Mônica Fix, Natália, Natalie Mas, Nicole Crochik, Normaci, Paula Galhego, Priscila Arcuri, Renata Bazzo, Renata Grinfels, Rosana Amá Brusco, Sabrina Veloso, Silmar Gannam, Simone Kubric Lederman, Thais Certain, Vânia Bueno de Souza.

A todos os estagiários e profissionais visitantes do Trapézio, que não deixam cessar a dúvida em mim, nem tampouco as certezas assentarem;

Aos pacientes do Trapézio, com quem aprendo continuamente a improvisar;

Às minhas irmãs, Cláudia e Lígia, amigas e companheiras queridas, em todos os momentos da vida;

Aos meus pais, para mim meus maiores testemunhos de amor e respeito que tive e tenho na vida;

Aos meus avós (in memorian), que sempre despertaram em mim saudades de um tempo que eu não vivi;

Ao Dr. Oswaldo, “o” figura necessário;

À Meire Gomes, pela revisão criteriosa, atenta e divertida!!! 


\section{RESUMO}

VASCONCELLOS, F.M. de. "Não sei ainda, posso pensar?": um estudo dos impasses escolares como um sintoma social. Dissertação (mestrado) - Faculdade de Educação, Universidade de São Paulo, São Paulo, 2012.

Esta pesquisa teve início com uma pergunta sobre por que a educação tem sido um campo mais reconhecido pelos seus obstáculos do que pelos seus ensejos. O que tem feito da educação um fato de difícil acontecimento? Para responder a isso, recorremos a uma teorização da psicanálise que versa sobre o encontro do sujeito do desejo com a cultura, permitindo uma leitura de seus atravessamentos e implicações para a subjetividade e para a educação. A identificação moderna da pedagogia ao discurso da ciência forjou na instituição escolar um cenário marcado pela segregação e pela intolerância às diferenças, a despeito do discurso da inclusão apontar para o contrário disso. Diante dessa situação, os sujeitos têm respondido com sua desimplicação, desaparelhando a educação de suas condições de possibilidade. A análise de um dispositivo institucional de tratamento permitiu acompanhar uma modalidade de resposta clínica a este contexto, que visa a recuperar a responsabilidade e a implicação, elementos imprescindíveis às aprendizagens e ao encontro com o outro na situação do laço social.

Palavras-chave: educação, psicanálise, cultura, sintoma social, impasses escolares, instituição. 


\begin{abstract}
Vasconcellos, F. M. de. "I don't know yet, can I think about it?": a study of the stalemates of education as a social symptom. Dissertação (mestrado) - Faculdade de Educação, Universidade de São Paulo, São Paulo, 2012.

This research begun by asking why education has been related more to its obstacles than to its opportunities. Why has education been seing as an event that happens with to such a difficult? To answer these questions, we used a psychoanalytic concept that tells us about the encounter of the subject of the desire with culture, which allow us to a reading of its crossings and implications for subjectivity and education. The identification of modern pedagogy to the discourse of science in the school has forged a scenario marked by segregation and intolerance for differences - despite the 'inclusion discourse' to point the opposite. Given this situation, the subjects have been responding with their disengagement, dismating education of its conditions of possibility. The analysis of an institutional arrangement allowed us monitoring a modality of clinical response, which aims to restore responsibility and involvement, which are indispensable elements to the learnings and to the encounter with other in the social ties.
\end{abstract}

Keywords: education, psychoanalysis, culture, social symptom, stalemates of education, institution. 


\section{SUMÁRIO}

Introdução

I - Do impossível da educação aos embaraços do educar ................................................

1. Do impossível da educação .......................................................................................

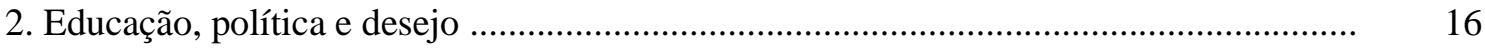

2.1. Isso que não se corrige e que insiste nos homens ........................................ 19

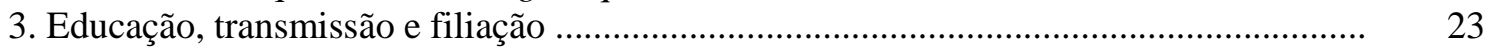

4. Dos embaraços do educar ...................................................................................... 26

4.1. O discurso da ciência como A verdade ...................................................... 27

4.2. Da paixão pela instrumentalidade ............................................................ 36

4.3. A impostura do não-limite na sociedade capitalista ...................................... 37

4.4. Unheimlich e Intolerância ............................................................................ 39

4.5. Da psicologização do cotidiano escolar ................................................................. 42

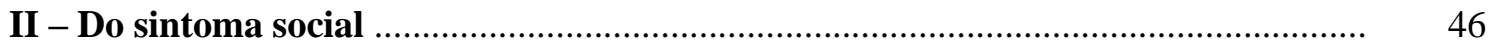

1. Do sintoma e do social ………............................................................................. 46

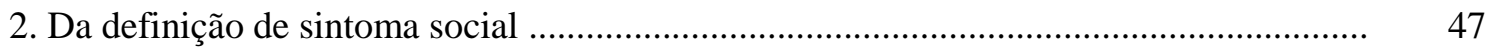

III - Dos problemas na escola aos impasses escolares como um sintoma social ......... 57

1. Dos problemas aos impasses ........................................................................ 57

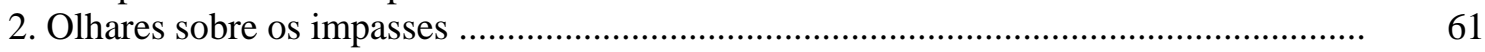

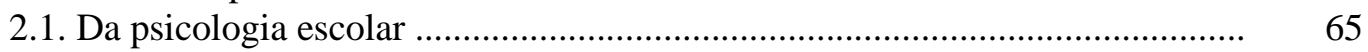

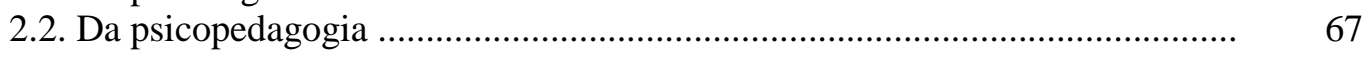

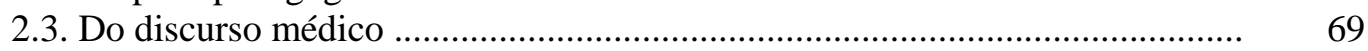

3. Dos impasses escolares como um sintoma social .................................................. 71

3.1. Da ideologia do rendimento: o fracasso é o reverso do sucesso .................... 75

3.2. Não há problema que uma falta de solução não possa resolver ..................... 76

IV - Análise de uma experiência institucional ............................................................ 79

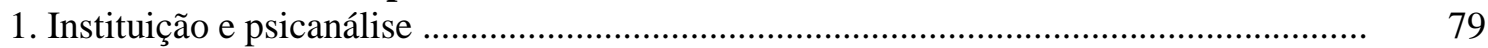

1.1. Bonneuil: uma instituição barrada (e uma fonte de inspiração...) .................... 81

2. Do enfrentamento do educativo ................................................................................. 83

3. O trabalho de apoio à escolarização:

da invenção de uma prática discursiva $n o$ social ............................................................ $\quad 86$

3.1. Das premissas que embasam o

dispositivo de apoio à escolarização do Trapézio ......................................... 88

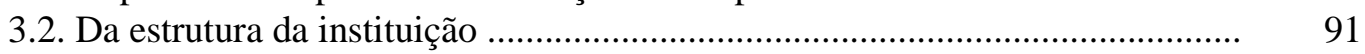

3.2.1. Da lógica das entrevistas preliminares ....................................... 91

3.2.2. Da ética da psicanálise .......................................................... 92

3.2.3. Da triagem .................................................................... 93

3.2.4. Do dispositivo de apoio à escolarização ..................................... 94

3.2.5. As oficinas: o trabalho em grupo, a dupla de coordenação, a produção e a escolha ......................................................................... 94

3.2.6. O trabalho do profissional de referência: a escuta dos pais e a interlocução com a escola .......................... 97

4. Caso Teresa: da invenção de uma barreira simbólica para enfrentar a demanda do Outro

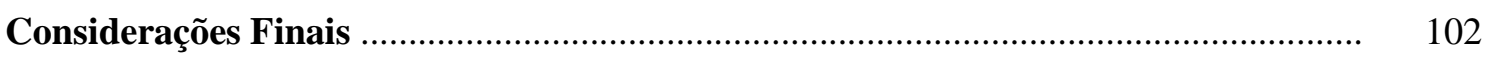

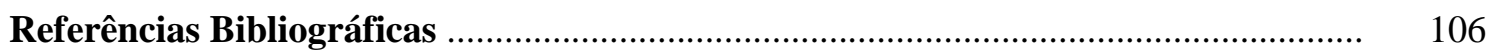




\section{Introdução}

Os impasses escolares como um sintoma social é a hipótese que traça o fio que permeará este estudo. Entretanto, mais do que uma tentativa de propugnar esta proposição, esta dissertação se propõe a fazê-la trabalhar.

Tomar os impasses escolares como sintoma social se constitui como um olhar outro sobre os problemas que comparecem no cenário escolar hoje. Trata-se de um viés que se distingue dos demais pela hipótese que o embasa, a saber, de que esses problelmas são efeito de um discurso pedagógico que se totalizou e se tornou intolerante com as diferenças, embora o discurso da inclusão tente "camuflar" isso.

No primeiro capítulo, apresentaremos um recorte do contexto educativo hoje, que se embaraça, ou se desvirtua, em função de uma dificuldade moderna de levar em consideração os limites que vêm do real. Entendemos que o não reconhecimento do impossível conduz a disposições totalitárias que, no campo educativo, se traduzem em ações de intolerância e segregação. A educação porta, inexoravelmente, elementos que dizem respeito ao impossível freudiano (ver seção 1, "Do impossível da educação", do capítulo 1), que aponta para o imponderável e para o imprevisível. A disposição daquele que sustenta uma posição de educar deve suportar e sustentar tais elementos; é isso que mantém um lugar minimamente esgarçado para o sujeito do desejo, oferecendo-lhe espaço para que este trilhe um percurso singular, em um campo cujo compromisso está atado ao bem público e cuja vocação é coletivizante.

Como efeito do discurso do capitalista (ver seção 4.3., "A impostura do não-limite da sociedade capitalista", do capítulo 1), que veicula balizas pautadas nos valores do sucesso e da eficiência, o homem contemporâneo quer acreditar que não tem inconsciente, banaliza as coisas do desejo até o ponto de fazê-las deslizar para necessidades triviais, que são supostamente aplacadas com objetos feitos sob medida. "Sua satisfação garantida ou o seu dinheiro de volta" é o lema de um discurso que propaga a ilusão de que, para toda necessidade, há um objeto correspondente. A matriz desse discurso pretende subverter a falta estrutural que compete aos homens, transformando-a em contingência, e fazendo do mal-estar, do qual Freud nos fala, um transtorno temporário que supostamente poderia ser regulado com base em técnicas específicas e objetos adequados. 
Tal disposição, como veremos no item "O discurso da ciência como A verdade", é engendrada discursivamente pelo do cogito cartesiano, que produziu uma separação entre saber e verdade. A partir de Descartes, a ciência passa a ambicionar o lugar de porta-voz da verdade e, extrapolando as fronteiras do campo científico, se imiscui no campo social, vulgarizando-se em um discurso social dominante. Com isso, promove a ilusão de que seja possível conter o imprevisível e controlar o imponderável.

No segundo capítulo, nos dedicamos à conceitualização da noção de sintoma social, recuperando o lastro de sua categorização dentro do campo da psicanálise.

Lacan afirmou que, depois do capitalismo, todo sintoma é social. No entanto, é preciso atentar para o fato de que, a rigor, Lacan está se referindo a um único sintoma, cujo inventor é Marx, que não é o oposto do sintoma particular nem a sinalização de uma psicopatologia do social: "há apenas um único sintoma social: cada indivíduo é realmente um proletário, quer dizer, não há nenhum discurso com que fazer laço social, ou dizendo de outra maneira, semblante" (Lacan, 1975 apud Askofaré, 1997, p. 177). Todos somos proletários, porque estamos submetidos ao fato de que a verdade não pode ser dita. A solidão imanente ao gozo resulta neste "déficit social", na ausência de um discurso que dê conta de dizer a verdade; é a isso que Lacan nomeia de sintoma social (Askofaré, 1997). Neste contexto, a mercadoria é emblemática desse sintoma social apontado por Lacan: ela é a prova de um deslocamento fálico que produz uma mudança da predominância do valor de troca sobre o valor de uso. O efeito disso é uma sobrevalorização do objeto e um consequente empalidecimento do sujeito (Voltolini, comunicação verbal).

A proposta de revisitar esse encontro do sintoma com o social foi iniciada depois de Lacan, por uma discussão feita pelo psicanalista Charles Melman ${ }^{1}$, que foi, subsequentemente, desdobrada por outros psicanalistas. Tal discussão se propunha a pensar a toxicomania como sintoma social, como metáfora de uma verdade da civilização contemporânea, situada entre o universal do mal-estar e o singular do sintoma subjetivo.

Discutir o conceito de sintoma social comparece como um desdobramento necessário de uma certa psicanálise interessada em manter seu vigor e seu compromisso com o sujeito

\footnotetext{
${ }^{1}$ MELMAN, Charles. Alcoolismo, delinquência e toxicomania: uma outra forma de gozar. São Paulo, Ed. Escuta, 1992.
} 
e com um pensamento sobre a civilização. Estando implicada ${ }^{2}$ com o social, essa psicanálise pretende criar respostas para mais além das questões subjetivas e fantasmáticas particulares de cada sujeito.

No terceiro capítulo, "Dos problemas na escola aos impasses escolares como um sintoma social", apresentamos a nossa tese segundo a qual, no contemporâneo, os problemas ou as vicissitudes de um percurso escolar têm ganho a conotação de “impasses”, por efeito de um discurso que se indispõe com as diferenças. Impasses estes que não dizem respeito apenas às dificuldades da criança em aprender, mas também de seu professor em manter-se na posição de quem ensina e de sua família, que se vê desautorizada em seu saber.

Além disso, discorreremos sobre três interpretações ou posições diante do fracasso escolar, a saber, a psicologia escolar, a psicopedagogia e o discurso médico, com o objetivo de situar a proposição que embasa esta dissertação dentro de um contexto mais amplo.

Para finalizar, o último capítulo apresenta a proposta de uma instituição que, partindo da leitura dos impasses escolares como um sintoma social criou um dispositivo para produzir mudanças nesse cenário.

\footnotetext{
${ }^{2}$ Rinaldo Voltolini propõe esta perspicaz resposta para a querela da psicanálise aplicada: a psicanálise não se aplica a nenhum outro campo, mas ela pode estar implicada em uma conversa entre os campos.
} 


\section{I - Do impossível da educação aos embaraços do educar}

\section{Do impossível da educação}
"Aquele a quem permitem fazer tudo o que deseja, em breve não sabe mais o que desejar."

(Robert Musil)

São dois os momentos nos quais Freud faz (breves) menções à ideia original do impossível da educação em sua obra.

Em 1925, prefaciando o livro de August Aichhorn ${ }^{3}$, afirma, ao tratar da educação, que seu objetivo é "orientar e assistir as crianças em seu caminho para adiante e protegê-las de se extraviarem" (FREUD, 1925, p. 341). No referido prefácio, inclui a educação no rol das profissões impossíveis, sem, contudo, deixar de advertir para o fato de que o impossível não deve conduzir à falta de empenho.

Já em “Análise terminável ou interminável”, texto de 1937 dedicado à discussão dos alcances e dos limites de uma análise, Freud faz figurar a psicanálise no rol das profissões impossíveis, com relação "às quais de antemão se pode estar seguro de chegar a resultados insatisfatórios" (FREUD, 1937, p. 282). Neste mesmo texto, porém, nos dá pistas de que o insatisfatório não tem para ele uma relação de equivalência com o irrelevante. É insatisfatório posto ser impossível uma solução absoluta, um ponto final que estabeleça, dali em diante, uma vida apenas acertada e sem conflitos. Sendo assim, a psicanálise não pretende fazer desaparecer as exigências pulsionais, logrando apenas produzir um "amansamento" de tais exigências (FREUD, 1937, p. 256).

A experiência analítica, diz Freud, ensina que o melhor é sempre inimigo do bom. O desejo de fazer cumprir plenamente um ideal desvaloriza as pequenas conquistas, que são precursoras das mudanças que realmente importam.

Foi em "Uma dificuldade da psicanálise", de 1917, que Freud desenvolveu a ideia de que a humanidade teria sofrido três golpes narcísicos ao longo de sua história. O primeiro, que ele chamou de astrológico, ocorre quando Copérnico, no século XVI, reafirma a hipótese, já anunciada no século III a.C. por Aristarco de Samos, de que a Terra não estaria no centro do universo. O segundo golpe, nomeado biológico, diz

\footnotetext{
${ }^{3}$ Juventude abandonada: a psicanálise no cuidado aos menores: 10 conferências introdutórias (tradução nossa). No original: "Verwahrloste Jugend: die Psychoanalyse in die Fürsorgeerziehung; 10 Vorträge zur ersten Einführung" (AICHORN,1925).
} 
respeito à descoberta darwiniana da evolução, que atestou aos homens uma ascendência animal.Por último, a própria descoberta da psicanálise do inconsciente, que conduz à constatação de que não detemos o controle absoluto sobre nossas pulsões, tampouco temos plena consciência dos assuntos que afetam nosso psiquismo. A esse último golpe, Freud denominou de psicológico e afirmou ter sido o mais contundente deles; talvez possamos acrescentar, o mais insolente.

O homem não é senhor em seu próprio castelo, é falível, limitado e muito mais mundano do que aspiraria ser. Sua consciência não equivale a seu eu, e seu eu não coincide com sua verdade. O sujeito da psicanálise é instável e não encontra definições precisas: a ele, contudo, é concedido o direito de intentar construir um lugar para si, um lugar peculiar, pois não há modelos que o determinem, apenas sugestões que o inspiram.

Os golpes narcísicos sofridos pelos homens o remeteram à sua própria solidão sem, no entanto, terem, na mesma medida, lhe conferido uma certa liberdade jamais antes experimentada.

A liberdade da qual a psicanálise nos autoriza falar é um tanto modesta, porém preciosa, concedida pelo aspecto linguageiro da vida humana. Para que um bebê se humanize, espera-se que este se banhe no tesouro simbólico de significantes ofertados por uma cultura e a eles se enlace em sua medida, a ponto de tornar-se apto a embrenhar-se no universo da palavra.

Diferentemente dos animais, nosso gregarismo está intermediado pela palavra, por sua necessária falta de precisão e por sua instabilidade. Mas é graças a esta (des)virtude, a esta impertinente claudicância, que somos abertos a significações infinitas. Não repetimos, como as abelhas, voos estritamente demarcados por sua natureza; a palavra conduz os homens por voos insondáveis, ao imponderável e ao sensível, à poética de um viver.

Justamente por efeito dessa irredutível condição errante que Freud postulará a ideia de que as profissões necessariamente mediadas pela palavra (o educar, o governar e o analisar) são impossíveis. A palavra nos lança ao inesperado, ao fora do controle, ao imprevisível. Não é possível fazer coincidir uma intenção com um resultado e calcular os efeitos de um dizer sobre aquele que o escuta. Nesses campos, requer-se daqueles 
que aí se arvoram a disposição para lidar com o imprevisto e para improvisar ações diante dele ${ }^{4}$.

A educação se ancora sobre o tênue e impalpável solo de uma promessa, de uma aposta em um futuro que, apesar de incerto, é vindouro, produzindo um engajamento com um vir a ser.

\section{Educação, política e desejo}

A educação é impulsionada pelo desejo. Desejo de que nossas crianças encontrem algum lugar no mundo dos adultos e de que a humanidade continue caminhando. É um compromisso com o vir a ser da criança e do mundo, e o faz em nome do desejo de que este sobreviva às mudanças geracionais; não no sentido de que o mundo se mantenha intocado e que possa ser replicado de uma geração para outra, mas no sentido mesmo de que ele não pereça, não ceda à violência e à barbárie própria dos homens.

Há um inconciliável descompasso entre desejo e vida em sociedade, entre sexualidade e civilização. Em “Totem e Tabu” (1913), Freud postulará a ideia de que a civilização decorre de um ato de violência: o assassinato do pai da horda, seguido de sua devoração, teria produzido nos homens a necessidade de refrearem seus impulsos, estabelecendo nosso gregarismo com base na culpa compartilhada pelos irmãos assassinos.

No processo de aculturamento, no qual estão imbricadas educação e constituição do sujeito, o homem precisa encontrar destinos para essa antinomia: é preciso que o homem seja capaz de sacrificar a satisfação plena de seus impulsos em prol da vida.

O mito da horda primeva narrado por Freud remonta à etiologia do sujeito psíquico e de seu engendramento no campo político. A horda traduziria o estado selvagem de agrupamento entre seres viventes, submetidos ao imperativo instintual. Por consequência da retroação de um ato (o assassinato do pai), estes teriam sido repelidos do mundo da natureza em direção ao campo da cultura, passando a sofrer os efeitos de seu poder de ordenação e de sua exigência de enquadre.

\footnotetext{
${ }^{4}$ Foi com Maria Cristina Kupfer que eu aprendi esta máxima da clínica psicanalítica: diante do necessário imprevisto dos acontecimentos, improvisamos uma intervenção.
} 
Deduz-se desse relato mítico que, tendo sido o pai assassinado, os irmãos teriam sido afetados a um só tempo por dois impulsos muito diversos entre si, e que se manteriam, ontologicamente falando (e, no entanto, com consequências filogenéticas), como marcas indeléveis do humano, articuladas de um modo sempre ambivalente. De um lado, crescerá, em cada um dos membros da horda, o desejo de ocupar o lugar do pai assassinado, seguindo seus próprios impulsos narcísicos; por outro lado, no entanto, e de modo surpreendente, origina-se um novo sentido entre os membros desta comunidade, até então inaudito: a exigência da regulação.

A existência de uma interdição sistemática ao gozo nos agrupamentos humanos é a evidência de sua vocação mortífera (MILLOT, 1992): seguir desenfreadamente os próprios impulsos constitui, indubitavelmente, uma ameaça à vida de um e ao modo gregário de organização das comunidades humanas. Será o pacto de renúncia que se estabelecerá entre os irmãos, restringindo a onipotência individual, que irá outorgar o direito à vida. E a cultura se moverá com base no mal-entendido que o campo da Linguagem obriga, erguendo-se sobre o mal-estar decorrente do encontro sempre ambivalente com o outro. Haverá, desse modo, desde sua origem, uma antinomia entre sexualidade e civilização, e, paradoxalmente, uma indelebilidade nessa articulação, que serão transmitidas de geração em geração.

Em “Totem e Tabu", encontramos um ensaio sobre transmissão e ambivalência (Endo, comunicação em aula, 2009). Transmissão, em Freud, de uma memória inata herdada, veiculada pela família, a respeito desses acontecimentos originais, que cada indivíduo seria obrigado a repetir, mas que encontraria, no âmbito privado, uma modalização em sua forma de atualização (MILLOT, 1992). Na releitura de Lacan (1992), no entanto, a transmissão é de uma ordem simbólica, que toma os homens como presas desde antes de seu nascimento, efetivando-se e atualizando-se na relação edípica, que é protagonizada pelos pais e seu bebê.

No que se refere à ambivalência, trata-se de algo que permanecerá como uma habitação estrangeira no próprio sujeito. Há algo que lhe é muito distintivo e próprio, mas que ocupa um lugar estranho, que não lhe parece nem íntimo, nem seu. Koltai (2000) sugere abordar a noção de estrangeiro como um limiar entre o campo do sujeito e o campo político, e aproxima o estrangeiro da noção de sintoma, já que este se situa entre o mais íntimo e singular do sujeito, e o mais universal do discurso no qual se inscreve. 
Seria tarefa da psicanálise buscar alguma reconciliação e uma maior familiaridade com esste objeto estranho, que foi excluído da consciência, mas que deve ser reintegrado. Permanecendo estrangeiro, encapsulado, tal qual o sedimento que é precipitado na reação química, ele não permite nenhuma dialetização; pelo contrário, sua vocação é a certeza, e, no campo político, isso se traduz em ideias totalitárias e na máxima de que o estrangeiro é o inimigo. O risco de tal entendimento, nas palavras de Primo Levi, é essa convicção, normalmente latente e desarticulada na maioria das pessoas, encontrar meios de se fundar sobre um sistema: "quando o dogma informulado é promovido ao nível de uma premissa maior, de um silogismo, então, no fim da linha, temos o campo de concentração" (LEVI apud KOLTAI, 2000).

A clínica nos revela e a história nos confirma: dialetizar é preciso. Para que alguma transformação seja alcançada, no âmbito do sujeito ou no campo político, é preciso reconhecer o conflito, levá-lo em consideração, trazê-lo para o primeiro plano. Se, ao contrário, o conflito é negado, em resposta à ambição de negar a dicotomia, o risco desse dogma informulado virar um silogismo se acirra perigosamente.

A civilização se estabeleceu baseada em uma ordem simbólica que foi capaz de suplantar a lógica do pai da horda; as regulações que aí se estabeleceram, relacionadas ao modo como os enlaçamentos entre os sujeitos deverão se dar, fazem uma intermediação entre o lugar da autoridade e o lugar do arbitrário, visando a diminuir o risco do individual sobrepujar o coletivo. É dessa operação que resta o mal-estar do qual Freud nos fala, um mal-estar inevitável, proporcional ao gozo que tivemos de renunciar. Para fazer uma aderência ao solo comum da tradição, é preciso submeter-se à lei da castração: o trabalho civilizatório se apresenta como uma emboscada que, ao mesmo tempo que vincula o sujeito à cultura, permitindo seu acesso ao universo simbólico (o que the confere uma certa liberdade de circulação social), encerra-o nessa trama simbólica (Petri, 2003). Submetendo-se à linguagem, o sujeito ganha em laço e perde em gozo. 


\subsection{Isso que não se corrige e que insiste nos homens}

“... descarregavam sobre ele o ódio que está sempre em todo mundo à espera de qualquer pessoa estranha, como uma tempestade iminente no ar."

(Robert Musil)

Em 1967, Palo Alto, California, um professor de história se vê confrontado com o desdém e a descrença de seu grupo de alunos diante do risco, sempre iminente, da autocracia se estabelecer como um regime dominante. Em resposta a isso, abdica temporariamente dos livros e dos debates, e dedica-se a empreender, na prática, uma vivência autocrática, incluindo, no espaço da sala de aula, os elementos centrais dos regimes nazistas e fascistas, que se pautam na obediência cega a um líder, no amor fraterno incondicional e na dessubjetivação. De um modo desconcertante e surpreendente, acompanhamos esse procedimento, adotado em nome da didática, escapar ao controle do professor, e transmutar-se em uma espécie de autocracia in vitro, induzida artificialmente, porém, fertilizada e operante. Essa é a trama do filme alemão "Die Welle", “A onda" (2008), dirigido pelo jovem diretor alemão Dennis Gansel, baseado em fatos verídicos.

O filme mostra a velocidade com que ocorre a pregnância dos ideais nazistas no grupo, sem que seus membros se deem conta exatamente do que está acontecendo. Acompanhamos, do lado do professor, o orgulho de estar conseguindo se comunicar com seus alunos, que estão lhe dedicando atenção, interesse e respeito. Do lado dos alunos, explicita-se a enorme força de atração que um líder e um grupo exercem sobre as subjetividades, conduzindo os membros do grupo a uma zona de indiferenciação e de dessubjetivação, que os leva a agir em nome de ordens proferidas pelo líder e a recusar qualquer evidência de contradição dentro do grupo. $\mathrm{O}$ amor se exacerba no interior do grupo e o ódio é dirigido a todos aqueles que não pertencem a ele, ou que o questionam de alguma maneira.

Quando finalmente o professor se dá conta da monstruosidade que tem em mãos e tenta colocar um basta, um dos alunos argumenta, indignado, que "A Onda", como eles se denominavam, também tinha tido pontos positivos e que eles não precisariam acabar com ele, mas apenas corrigir os seus erros. Diante disso o professor responde: "isso não tem como se corrigir".

O que é isso e por que não tem como se corrigir? 
O fato ocorrido em Palo Alto evidencia que as circunstâncias históricas não podem ser tomadas de modo isolado para responder pelas escolhas realizadas pelos homens em seu tempo: o eixo das contingências se cruza com o eixo da estrutura. Afinal, não fazia parte do contexto daquela sala de aula nenhum dos elementos presentes na República de Weimar e que facilitaram a ascensão do nazismo: fome, miséria, desemprego, recessão ou o trauma de uma guerra perdida. O que, então, mobilizou esse grupo nessa direção? O que permitiu a precipitação dessa aderência a ideais até então tão distantes, ou até mesmo tão desconhecidos?

Parece que o "procedimento didático" empreendido pelo professor tocou em um ponto da subjetividade de cada um que diz respeito ao horror de se reconhecer dividido, incompleto, castrado; horror que encontra, na figura do líder e no laço fraterno entre seus pares, um apaziguamento, uma espécie de sutura da falta fundamental, que convida a pulsão a circular em um circuito fechado e previsível, obliterando, de modo ortopédico, mas com muita eficiência, a dor de sua incompletude.

Isso que não se corrige diz respeito a uma falta estrutural, imanente, que sempre mobilizará o homem de um modo ambivalente: amor e ódio em relação ao Pai. Por um lado, esta é a mecânica do desejo, que im-pulsiona o homem na direção de um viver; por outro, trata-se do esburacamento produzido pela linguagem, sofrido de modo traumático e violento pelo sujeito, que o percebe como morte.

A intolerância dirigida ao estrangeiro é fruto da ambição de superação dessa dicotomia: quanto mais se quer fundar uma sociedade no amor, mais se intensifica o ódio pelo outro, quanto menos estivermos dispostos a incluir esse estrangeiro, mais longe estaremos da possibilidade de elaboração, e mais próximos estaremos da passagem ao ato. Dito de outro modo, quanto menos estivermos familiarizados com o estranho que há no interior de cada sujeito e de cada grupo, mais acirrada se dará a segregação, que é, no entendimento da psicanálise, um ódio dirigido ao gozo do outro (KOLTAI, 2000). Na construção fantasmática do sujeito, se eu não gozo é porque o outro me subtraiu isso como possibilidade, o excesso de um, dentro desta lógica, produz a escassez em outro (ibidem).

Na releitura de Lacan (1992) de "Totem e Tabu", depreendem-se dois conjuntos: de um lado, tem-se o pai da horda, o "ao menos um" não submetido à castração, que dá suporte ao outro conjunto, dos filhos, submetidos à castração e marcados pelo desejo de alcançar um gozo absoluto, que lhes é barrado. No entanto, permanecerá a crença entre 
eles de que "ao menos um" estaria fora do desígnio da linguagem e, portanto, do imperativo da castração.

A contemporaneidade, hegemonizada pelo discurso do capitalista (ver seção 4.3., deste capítulo), encontra no discurso da ciência (ver seção 4.1.) seu corolário, ao produzir uma obnubilação da barra que separa o sujeito do gozo. De fato, ao homem contemporâneo são oferecidas, a uma só vez, a desresponsabilização pelos seus atos (produzida por um discurso cientificista que se pretende universal, não deixa brechas para o imprevisto e que toma, discursivamente, os sujeitos no lugar de objeto) e oportunidades efêmeras de gozo, que, apesar de sua fugacidade, mantêm o sujeito preso a um gozo, a uma repetição, como no mito de Sísifo: por mais esforço que este despenda pra fazer a pedra rolar morro acima, e por mais que, tão logo tenha chegado em seu ápice, ela sempre corra morro abaixo, ainda assim esse sujeito sisifiano, vamos dizer assim, manter-se-á capturado em um lugar do qual não pode se safar.

Quanto mais se caminha na direção de uma uniformização dos homens, mais se produz sua dessubjetivação, mais se ignora sua divisão: o resultado dessa operação é a exclusão do resto, que se apresenta como estrangeiro ${ }^{5}$. É por isso que Lacan dirá que a segregação se intensifica quanto mais o gozo se apresentar como imperativo.

A história da subjetividade no mundo ocidental nos aponta para outras possibilidades de engendramento do homem e seu estrangeiro no campo político. É absolutamente moderna a ambição de se pautar em um discurso de certeza sobre a vida, um discurso, diga-se de passagem, que se pauta na idéia de que é o conhecimento do corpo o que dá a medida da dignidade da vida ${ }^{6}$ (FREIRE COSTA, 2008). A busca de sentido para a vida hoje se pauta pela supravalorização da certeza pleiteada pelo discurso da ciência, que

\footnotetext{
${ }^{5}$ Lacan inventa a idéia de êxtimo para dar conta da noção de um estrangeiro que está dentro e fora ao mesmo tempo, um conceito que comporta em si a ambivalência da qual os homens não têm como se esquivar e que confere à análise das subjetividades a complexidade que lhes é concernente. A leveza do homem contemporâneo não é sustentável (LAURENT, 2007).

${ }^{6}$ A dignidade da vida (Bios) foi considerada pelos gregos como aquela que se daria no campo da pólis democrática, enquanto a vida indigna (zoé), não qualificada, seria aquela reservada ao campo privado. A zoé grega fazia referência a um resto de vida animal, não domesticada. Diferente dos romanos, que, sob a figura do homo-sacer, banem a vida nua da comunidade, os gregos acreditavam que esse resto poderia ser objeto de acometimento e ascensão. A vida nua, para os gregos, implicava uma servidão do próprio homem à necessidade. Sendo assim, zoé e bios traduziam um modo grego de interpretar a ambivalência inerente à vida, segundo a qual a vida não qualificada não é tomada como um corpo estranho, como um estrangeiro, pelo contrário, a vida nua, para os gregos, compunha, juntamente com a vida digna e qualificada da bios, uma só vida. Uma vida que buscava balizar-se na verdade para encontrar um sentido. O importante desse sistema de pensamento é que a verdade não define o homem "de um modo exaustivo e deixa uma possibilidade sempre em aberto para uma definição outra” (FREIRE, 2008).
} 
persegue respostas absolutas, exaustivamente, não deixando nenhum espaço para a reinvenção do homem.

São muitos os efeitos disso sobre o campo da educação. Hoje, os fenômenos da multiplicação dos diagnósticos e dos excessos de medicalização no cenário escolar parecem responder a um modo de funcionamento social que transforma muito facilmente dificuldades em transtornos e vicissitudes em distúrbios, levando à patologização dos processos envolvidos nas situações de ensino e aprendizagem, e ao apagamento do sujeito. Aquilo que, do sintoma (o não aprender, por exemplo), poderíamos ler como demanda de reconhecimento do Outro, demanda de autenticidade e de ser escutado para encontrar um lugar, fica reduzido ao resíduo que deve ser eliminado.

A afirmação de Elizabeth Roudinesco (2000) segundo a qual o homem atual se transformou no contrário de um sujeito corrobora essa discussão. O sujeito se esvazia das marcas que lhe são mais peculiares e que lhe humanizam, a saber, as marcas do desejo.

Segundo o psicanalista Contardo Calligaris (1994), a educação atual está edificada sobre uma promessa de um gozo sem desejo. Essa vetorização que se faz em direção ao futuro, não estando balizada pelo desejo, mas sim por uma exigência social de enquadramento a um ideal, não consegue focar um ponto de chegada. O que se produz é uma errância, o sujeito vagueia. Além disso, no discurso pedagógico atualizam-se os anseios deste corpo social que tende a transformar toda falta em falha, ao perseguir um "ideal de educação" que pretende ter respostas para tudo, não deixando brechas para o imprevisto e, como consequência, para o desejo. Com isso, a pedagogia fica submetida ao discurso do universitário, identificando-se à função aplicativa da ciência, para a qual há um saber sem sujeito, que coloca o outro no lugar de objeto. $\mathrm{O}$ resultado dessa operação é que a criança é tomada desde o lugar de quem nada sabe, e o saber suposto no lugar do Outro.

Isso posto, resta-nos a pergunta sobre qual destino dar para isso, visto que isso tem mobilizado nossos piores humores. De algum modo, é preciso fazer frente à inércia característica de tal disposição: a tendência contemporânea tem conduzido ao pior. Nesse cenário, o campo educativo tem se tornado um campo de batalha entre o desejo de nada desejar e o desejo de fazer desejar. A educação, no entanto, depende do desejo 
para cumprir sua função. Se esse elo se rompe, vemos encamparem-se as condições para uma “educação pervertida” (MANNONI, 1973 apud LAJONQUIÈRE, 2010).

Entendemos que restabelecer um lugar para isso, que insiste em não se deixar simbolizar, mas que, no entanto, permanece como húmus do desejo, é uma tarefa da educação.

\section{Educação, transmissão e filiação}

"O que foi que se perdeu? Algo imponderável. Um presságio. Uma ilusão. Uma doença misteriosa devorou a pequena genialidade dos velhos tempos (...) e por fim não se sabe mais se o mundo realmente ficou pior, ou se apenas nós ficamos mais velhos."

(Robert Musil)

Em seu único ensaio dedicado à educação, “A crise na educação”, escrito em 1958, Hannah Arendt afirma que a educação decorre do fato de que as crianças nascem para o mundo, o que impõe aos adultos uma dupla responsabilidade: pela vida da criança e pela continuidade do mundo. A função da educação é a de transmitir aos recémchegados nosso legado cultural, nossos valores, nossa tradição, e garantir que estes deem continuidade ao mundo.

Em outra perspectiva, mas de modo muito semelhante, a psicanálise dirá que a educação deve produzir marcas simbólicas capazes de filiar uma sujeito a uma cultura, hominizando-o, socializando-o e permitindo que este se singularize (VOLTOLINI, 2010). Hominizar é estabelecer condições compartilháveis, às quais a criança deve, num primeiro momento, alienar-se para, apenas ulteriormente, poder se separar: hominizar é fazer do pequeno rebento um ser humano. Socializar diz respeito à função da educação de conduzir ao laço, de permitir que a criança, tendo sido tocada pela cultura, se dirija e se enlace a seus semelhantes. E, por fim, singularizar aponta para a tarefa mais auspiciosa da educação: a de permitir que cada um se humanize e se enlace à cultura a seu modo, guiado pela verdade de seu desejo, vetorizado por um eixo absolutamente incomum e particular.

À educação caberá a tarefa de dosar suas funções: é preciso que a criança acate um modo universal de vida dos humanos, sem, no entanto, se deixar submeter por completo; é necessário que ela aprenda a conviver com seu semelhante e suas diferenças, e com toda a hostilidade que este lhe desperta. Dizendo de outro modo, a 
criança terá de aprender a atentar para suas próprias exigências sem deixar de considerar o próximo e os limites que este impõe à satisfação de suas exigências pulsionais. A educação depende de um bom senso na aplicação de suas regras. É como uma cozinheira que deve dosar a quantidade de tempero a ser utilizada em cada prato.

Com relação a isso, Hannah Arendt explicita, no mesmo texto já citado (ARENDT, 1997), que, no mundo moderno, constata-se uma perda do sentido compartilhado, do senso comum, o que conduz ao que ela chama de "perda em mundo". É o senso comum que equaciona os sentidos próprios (o campo do sujeito) e a linguagem (o campo do Outro), tornando os sujeitos passíveis de conviverem uns com os outros, apesar do abismo que os separa e da hostilidade que os une. A perda do senso comum na sociedade moderna é, segundo Arendt, o melhor indicador de que vivemos uma crise, articulada, segundo ela, à crise do mundo moderno.

Com base na análise do contexto educacional americano na década de 1950, no qual ela localizava um “declínio (...) crescente nos padrões elementares na totalidade escolar", Arendt retira elementos essenciais para pensarmos a educação, bem longe das fronteiras norte-americanas e muito além dos meados do século XX. O esvaziamento das tradições públicas e a falta de engajamento com um futuro traduziriam o descompromisso do homem contemporâneo com a humanidade e a civilização.

Sabemos que à educação cabe a tarefa de oferecer às crianças um lugar no mundo dos adultos. Seu campo está necessariamente tensionado pela ideia de futuro, um futuro que se almeja, que se espera, e que deve, na medida do possível, comparecer como hospitabilidade, apresentando às crianças um lugar interessante e convidativo. No entanto, sem as marcas do passado e da tradição, o homem fica esvaziado, sem estofo, inconsistente para dar conta de responder a seus dilemas presentes e a suas demandas futuras. E essa expectativa (ou esperança) de qual seja este futuro está submetida a nossa relação com o mundo nos dias atuais e ao valor que dispensamos a nossa tradição, ao amor e ao ódio que nutre hoje as relações entre os homens, e as relações dos homens com o mundo. A proposição arendtiana de um enlace entre passado e futuro traduz muito apropriadamente o laço que se deve manter para que a educação se efetive.

É possível constatar facilmente, no entanto, a fragilidade desse laço. No discurso acerca da educação hoje, observamos, de um lado, um desvalor em relação a tudo que remete ao passado, à história de nossa cultura, ao nosso conhecimento acumulado, a nossa 
tradição ${ }^{7}$; por outro lado, escutamos insistentemente uma preocupação vazia com o futuro - ser alguém no futuro, alguém em condições de sobrevivência em um mundo altamente competitivo e cada vez mais caro, um mundo utilitarista e pragmático, que vive uma crise de valores e tradição (de mal com seu passado, como observou muito precisamente Hannah Arendt) e que não acena com muito mais do que a possibilidade do gozo, do desfrute imediato, concedida pelos objetos de consumo, sempre tão atraentes, mas tão fugazes. O futuro que se esboça aí está capturado por um ideal individualista, pouco ou nada articulado a um compromisso com o mundo.

Hannah Arendt afirma que é na educação que se revela o amor (ou o ódio) dos homens pela civilização. E o homem contemporâneo vem atualizando neste campo o seu malestar, a sua insatisfação com o mundo, recusando-se a assumir, diante das crianças, uma responsabilidade que deveria ser sua. Articulada à crise na educação, comparece também uma crise da autoridade, marcas incontestáveis dos impasses hoje vividos pela educação neste campo, que banalizaram violência e barbárie, revelando a excessiva desimplicação e o grande descompromisso do homem com nosso mundo.

A desimplicação dos adultos dispensou as crianças de uma almejada autoridade e as conduziu a uma emancipação forçada, o que as expôs à tirania da maioria (esta sim uma tirania feroz e contundente). A criança, banida do mundo dos adultos, tem de, sozinha, encontrar meios de responder a seus semelhantes, o que lhe é vetado pela própria condição de minoria em que ela se encontra em relação a seu grupo. Perante isso, a criança responde com seu conformismo ou com sua revolta (ARENDT, 1997).

Os problemas nas aprendizagens ou as inúmeras questões relacionadas à indisciplina podem ser lidos, à luz das ideias arendtianas, como tentativas de equacionamento da situação de abandono à qual as crianças foram expostas.

$\mathrm{O}$ adulto moderno, de mal com seu passado, desimplicado do seu presente e desobrigado de suas responsabilidades com o futuro, não pode ler, nas dificuldades apresentadas pelas crianças, um alerta sobre a sua própria condição claudicante. Lança mão, então, de discursos (pseudo)científicos para proteger-se de sua própria fragilidade.

\footnotetext{
${ }^{7}$ Hannah Arendt afirma que o homem moderno está de mal com seu passado; de modo semelhante, Adorno fala em "aversão à educação", em "ressentimento", em hostilidade dirigida à formação, sentimentos que ele reconhece nos jovens alemães no pós-guerra (ADORNO, 1995, p. 150).
} 
Com isso, estabeleceram-se as condições para um panorama favorável à entrada de discursos ideologicamente determinados, que promovem uma báscula da responsabilidade para a culpa, e da implicação para a desobrigação.

\section{Dos embaraços do educar}

A educação exige certas condições para se efetivar. Não há como educar sem se implicar e sem correr certos riscos. $\mathrm{O}$ adulto na posição de educador transmite uma tradição, mas o deve fazer em nome próprio, assumindo aí uma autoria. Educar em nome dos manuais, fenômeno bastante frequente nos tempos atuais, isenta o adulto da responsabilidade por suas escolhas e pelos seus atos, afinal, em última instância, se algo fracassar, ele pode acusar um outro. Os adultos de hoje não querem assumir responsabilidades nem riscos; acreditam em fórmulas mágicas e querem garantias de sucesso. O modelo científico caiu como uma luva nesse contexto marcado por ambições de controle e previsibilidade, tornando árido o campo educativo e impondo mais embaraços do que ensejos à transmissão e à formação.

A pedagogia se equivoca ao acreditar ser possível equipar os homens de um modo exitoso e definitivo para os imprevistos da vida. Apesar do conhecimento ser sempre caracterizado por uma ambição de completude, a psicanálise nos revela que o conhecimento é sempre parcial, tendendo ao mal-entendido.

Um limite se impõe à formalização. Da operação que resulta da ambição de se recobrir o real a partir do simbólico, sempre permanecerá um resto. Por isso, por maior que seja o esforço feito na direção de se equipar devidamente uma criança para o mundo, este intento sempre se verá fracassado ou, dito de outra forma, se dará de um modo não todo.

Ainda que os vários percalços que podem ser vividos por uma criança ao longo de seu processo de escolarização sejam designados nesta dissertação por impasses escolares, é preciso reconhecer no conceito de "fracasso escolar" algo bem preciso: colocar em destaque que a pedagogia, animada pela ilusão de assertividade, crente em uma positividade que possa garantir seus rumos, só pode ter como destino o fracasso.

Como já afirmamos no capítulo anterior, a educação, bem como a política e a psicanálise, compartilham de um traço comum: todos esses três campos relacionam-se 
com o impossível. E a pedagogia, que não se confunde com a educação, mas dela é tributária, tem de lidar com o desafio de não tentar fazer coincidir ilusão com realidade, não subvertendo o impossível em impotência ou insuficiência.

Neste capítulo, pretendemos recuperar o lastro dessa ilusão de completude que anima o discurso pedagógico contemporâneo. Entendemos (apesar de o discurso manifesto da inclusão apontar para o contrário disso) que a intolerância perante o inesperado e ao estranho dentro da sala de aula nunca se apresentou de modo tão contundente. É fato que a empreitada de se ter todas as crianças em idade escolar matriculadas e frequentando as escolas é relativamente recente. Isto implica questões de ordem prática que tangem a implementação de novas políticas públicas que visam a fazer da escola, até poucos anos marcada pelo homogêneo, um lugar de diversidade.

No entanto, pretendemos privilegiar a leitura desse cenário baseando-nos em uma escuta posta no discurso pedagógico que, como veremos, ao identificar-se com o discurso da ciência, recebe como herança dessa filiação uma ambição totalizante e uma intolerância diante da verdade do sujeito, ao singular, ao inesperado e ao estranho.

\title{
4.1. O discurso da ciência como $A$ verdade
}

\author{
"O mundo é realmente cômico, \\ analisado do ponto de vista da técnica \\ (...) quem possui uma régua de cálculo, \\ e encontra alguém que faz afirmações grandiosas, diz: \\ um momento, primeiro vamos calcular \\ as margens de erro e o valor mais provável de tudo isso."
}

(Robert Musil)

Em primeiro lugar, é preciso deixar claro que o nosso objeto neste capítulo não será analisar a ciência como um todo, mas sim aquilo que Lacan chamou de o discurso da ciência. Este decorre do cogito cartesiano, tornou-se aliado da ambição do discurso do capitalista de tudo poder, e tornou-se hegemônico (não homogêneo!) no mundo contemporâneo.

Para Lacan, a ciência genuína não exclui o real de seu campo e não busca conciliações;

o verdadeiro espírito científico é movido pelos paradoxos e não pelo desejo de apagálos. É por isso que Lacan, na década de 1970, irá identificar a verdadeira ciência ao discurso da histérica, que tem escrito no lugar da verdade, o real, o "furo" não preenchível do simbólico; no lugar do agente, o sujeito barrado, que marca a primazia 
da divisão subjetiva, e que se dirige ao outro, demandando-lhe um saber. A produção no discurso da histérica é o prazer que ela extrai do saber (FINK, 1998).

O discurso da ciência (ou o discurso tecnocientífico ou, ainda, o cientificismo), como veremos, é aquele que se deixou seduzir pela ambição de recobrir completamente o real pelo simbólico, não tolerando as marcas de possíveis contradições e extirpando de seu campo tudo aquilo que possa vir a se apresentar como ameaça a essa pretensão de completude.

Essa discussão é pertinente para este estudo na medida em que reconhecemos uma identificação do discurso pedagógico com esse discurso tecnocientífico, seduzido a tal ponto pela técnica que se tornou instrumento ideológico.

O que nos importa, para o contexto deste trabalho, é pensarmos o impacto do discurso da ciência no campo social, e de que modo, mais especificamente, o campo pedagógico é afetado por essa expansão da ciência e da técnica para além de seus domínios, e pela ambição totalizante posta no discurso tecnocientífico que se enraiza no socius, ${ }^{8}$ definindo um modo contemporâneo de estabelecimento do laço social.

Toda ciência se constitui pela ambição de um desvelamento e apreensão do objeto que ela estuda. O campo científico veicula um código, que é compartilhado no interior de seu campo de estudo, legitimando as descobertas aí realizadas e tornando possível a transmissão desse conhecimento. Dito de outra forma, toda ciência se constitui por um discurso formal que se organiza sobre um determinado objeto, dentro de um campo de tradição, pelo qual se intenta tornar compartilhável esse conhecimento.

No campo da ciência, questões acerca da coerência, legitimidade e veracidade do conhecimento, e de sua capacidade de impacto no interior de seu campo, sempre foram altamente valorizadas. Mas a ciência experienciou, ao longo de sua história, a inflagem de uma ambição que extrapola os limites da preocupação investigativa: do cogito cartesiano aos dias atuais, viveu, de um modo crescente, a ambição de afirmar-se como o discurso da verdade. O discurso da ciência almeja ser detentor de todas as respostas: de seu ponto de vista, não há o inexplicável, apenas enigmas que demandam mais tempo para serem decifrados (VOLTOLINI, comunicação pessoal). É esse lastro da origem da ciência moderna e da fundação do discurso da ciência que Lacan recupera em sua discussão sobre a ciência e a verdade (1965).

\footnotetext{
${ }^{8}$ Socius: "companheiro, aquele que se associa com outro em uma empresa" (COUTINHO JORGE, 2002, p. 20).
} 
Ao retomar a genealogia da ciência moderna, Lacan recupera o contexto do nascimento de um discurso que irá inculcar, no laço social, uma intolerância à verdade do sujeito. Descartes funda a ciência moderna, que é erigida sobre um cenário de divórcio entre verdade e ciência. Essa cisão enraizou-se de tal modo no campo social que hoje essa verdade (entendida aqui como o lugar de enunciação do sujeito) está banida ou banalizada não apenas do campo científico, mas de todo o corpus social, que acata, no interior de seu modus operandi, um horror por tudo que não seja objetivável.

Em "A ciência e a verdade" (1965), Lacan se desincumbe do compromisso de ancorar a psicanálise no campo científico e afirma que a ciência ainda não está à altura da tarefa de acomodar a psicanálise. Será também nesse escrito que Lacan irá afirmar que a psicanálise só pôde advir após o nascimento da ciência moderna: o objeto da psicanálise equivale justamente ao resto da operação formal que, apesar de se caracterizar por uma ambição totalizante, de uma formalização absoluta, jamais logra completamente seu intento.

Descartes visava a alcançar a certeza inabalável, um ponto indubitável, ao qual ele paradoxalmente ascende elevando a dúvida a seu mais elevado grau. Coloca em questão tudo, até as operações matemáticas mais simples. No pensamento, encontrará a certeza de sua existência. O pensamento, ou seja, as ideias que se constituem internamente sobre a realidade objetiva, são entendidas por Descartes como efeito proporcional de uma realidade formal que causa o pensamento. Ao aplicar a esse princípio de causalidade a noção de infinito, Descartes deduzirá a existência de Deus: como é possível que em um ser pensante finito se constitua a noção de infinito? Como efeito de uma realidade formal que é exterior ao ser pensante, que se constitui como causa de todas as ideias enquanto realidades objetivas (LEOPOLDO E SILVA, 2005). Essa causa para Descartes é Deus.

Vejamos como Leopoldo e Silva explica esta afirmação:

Deus é o fundamento da verdade, ou seja, todas as representações que se me apresentarem metodicamente como claras e distintas estão garantidas por Deus, verdade suprema e razão de ser de todas as demais (...) não há por que, a partir daqui recear que algo que se me apresente com absoluta clareza e distinção possa ser uma representação falsa (ibidem, p. 60).

Isto porque Deus não induziria ao equívoco. 
Foi assim que Descartes produziu um corte entre saber e verdade, libertando "o homem moderno do ônus da verdade" (LACAN apud FINK, 1997, p. 73): "um pós-cartesiano podia finalmente abandonar as citações da Bíblia a cada passo, e começar a tecer uma rede de ideias que se mantivessem sobre suas próprias pernas" (ibidem, p.73).

Do divórcio entre saber e verdade nascem, a um só tempo, a ciência moderna, que almeja se ocupar apenas do que for supostamente objetivável, aceitando e gozando da forclusão da verdade de seu campo, e a psicanálise, que contrariamente, irá se responsabilizar por essa verdade.

O cogito de Descartes inaugura o sujeito, na exata medida em que introduz essa divisão no campo do pensamento, que até então era inaudita: saber e verdade constituem-se como campos radicalmente não coincidentes. A verdade sobredetermina o saber, e o saber questiona a verdade; eles estão imbricados, porém não misturados de um modo homogêneo.

A verdade da qual a psicanálise se ocupa é aquela que causa o sujeito desde um lugar que a este é desconhecido. E, a verdade só caberá no campo da ciência moderna após uma operação de redução da mesma a um tipo de valor, que a descaracteriza completamente em relação a seu caráter transgressor e disruptivo, porque a essa ciência só interessa o mundo cognoscível. A lógica que organiza o discurso dentro desse campo é proposicional. Trata-se de uma lógica para a qual os elementos do sistema não podem adquirir valor de um modo independente, só é possível lidar com os termos "verdadeiro" e "falso", que são valores de verdade definíveis dentro de um sistema fechado.

A verdade da psicanálise irá conduzir a uma afirmação avessa à de Descartes: "Penso onde não sou, sou onde não penso". Essa verdade não está atrelada a unidades de valor, é ela que, de fora desse sistema cartesiano fechado, indagará os homens com seu enigma e os causará.

Nada se diz que não se apoie na causa, afirma Lacan (1965). E é por isso que Lacan irá recortar a ideia de Descartes para extrair dela aquilo que lhe parece ser a sua essência: cogito ergo sum é traduzido por Lacan por cogito ergo $^{9}$, revelando que o pensamento

\footnotetext{
${ }^{9}$ Lacan dialoga com Heidegger neste ponto, uma vez que este tinha proposto uma algebrização diferente da frase de Descartes, ao suprimir o ergo; cogito sum traduziria a condensação da ideia de coesão entre pensar e ser, própria ao pensamento heideggeriano.
} 
não causa o ser, o pensamento é causado desde um lugar de verdade ao qual o sujeito não tem acesso e controle.

Mas retornemos ao Cogito ergo sum para acompanharmos como ele se constituiu como marco tanto para a ciência moderna como para o sujeito barrado.

O projeto cartesiano de hiperbolização da dúvida eleva a razão a sua máxima potência. Através da dúvida, Descartes desvencilha-se do conhecimento intuitivo e imediato do senso comum. Paradoxalmente, o lugar da dúvida coincidirá com o lugar da certeza (da certeza da existência), mas uma certeza que só se estabelece na medida em que a verdade estiver garantida por outra instância que não o pensamento. Dito de outro modo, Descartes encontrará no pensamento uma certeza inabalável do ser (se penso, existo). No entanto, irá se dará conta de que não há nele (o pensamento) uma garantia de sua própria verdade, conduzindo-o à busca de uma instância exterior ao sujeito que a legitime; como já dissemos acima, essa instância para Descartes era Deus.

O cogito de Descartes "libera" o sujeito da verdade: seu lugar de enunciação está garantido, não é preciso se ocupar dele; cabe ao sujeito ocupar-se dos enunciados, de buscar, através do pensamento e da razão, uma coerência entre eles.

É possível pensar a psicanálise como filha lógica do cogito de Descartes, na medida em que ela é signatária da divisão entre saber e verdade inaugurada com o projeto cartesiano. Também é possível pensar a ciência moderna como filha lógica de Descartes, uma vez que este inaugura uma dicotomia radical entre os campos da enunciação e dos enunciados. Por meio dessa operação a verdade se viu forcluída do campo da ciência e o desejo foi reduzido ao desejo de saber.

Todas as ciências, desde então, nos dirá Lacan, compartilharão de um elemento comum: do sujeito sem causa. Em outras palavras, a ciência passa a se pautar pela ambição de eliminar o inexplicável, e fundar um sujeito sem afeto, não corrompido pelo indesejável e obscuro desejo, que torna as coisas sempre tão imprevisíveis e incontroláveis.

Em seu comentário sobre o texto "A ciência e a verdade", Ana Beatriz Freire (1996) faz uma leitura psicanalítica de duas noções de constituição de sujeito que são introduzidas com Descartes: em primeiro lugar, o sujeito se constitui como nada mais que um resíduo, seu lugar de certeza é fugaz, evanescente, posto coincidir com seu lugar de 
dúvida ${ }^{10}$; em segundo lugar, será apenas na relação transferencial com o Outro (suposto saber) que o sujeito poderá ter notícias de seu desejo.

Esse sujeito-resíduo, que se afirma na incerteza e que comparece nos interstícios entre os significantes, é tudo aquilo sobre o qual a ciência nada-quer-saber. Como já foi dito, o compromisso da ciência não é com a verdade, mas sim com o verdadeiro ${ }^{11}$ : é suficiente para ela garantir uma coerência interna entre os enunciados para fomentar aquilo que a anima, que diz respeito à ilusão de que o simbólico possa recobrir o real (VOLTOLINI, comunicação em aula). A história da ciência é a história de uma perseguição à enunciação, e do progressivo assujeitamento dos sujeitos a enunciados que advêm do campo do Outro de um modo totalitário.

A ciência forclui a verdade, o campo da enunciação, com o objetivo de garantir uma isenção e uma impessoalidade no procedimento, e de manter à distância os efeitos sempre imprevistos da presença do sujeito. Para se aproximar da verdade, é preciso se distanciar da perniciosa influência da singularidade: esta é a lógica que subsidia a ambição da matematização do mundo.

Os enunciados desconectados de seu lugar de enunciação produzem um apagamento do sujeito. A psicose é um exemplo dessa cisão e de seus efeitos sobre o sujeito, que ocupa o lugar de objeto; mas é possível ocupar o lugar de objeto fora da estrutura psicótica; é possível, no laço social, ser tomado como objeto, ou colocar-se como objeto, sem que isso esteja referido a uma posição estrutural, mas sim a uma posição discursiva.

O laço social ${ }^{12}$ dominante na contemporaneidade se caracteriza por um encontro que tem, de um lado, um discurso que pede ao sujeito que não compareça, e, de outro, um

\footnotetext{
${ }^{10}$ Em "A ciência e a verdade" (1965), Lacan irá propor uma homologia entre Freud e Descartes: o conteúdo manifesto do sonho, que se apresenta de modo obscuro, incerto e não todo, é signo daquilo que o causa, do lugar da verdade e da enunciação do sujeito. De modo semelhante, Descartes encontrará no pensamento, através da dúvida, a certeza irredutível do ser.

${ }^{11}$ Ao excluir a verdade de seu campo, a ciência moderna pode apenas lidar com os termos "verdadeiro" e "falso", que são valores proposicionais em uma lógica discursiva que não pode lhes oferecer valor de verdade isoladamente, mas apenas dentro de um sistema fechado de combinatórias (FINK, 1997). Da verdade se ocuparão, daí para frente, cada uma a seu modo, a filosofia, as artes e a psicanálise. A verdade da qual nos fala Lacan é a verdade da impossibilidade da relação sexual.

${ }^{12}$ É importante observar que falar em laço social não equivale a falar em relação social; laço social implica a possibilidade de estabelecer algo em comum com o outro baseando-se em uma referência comum, que é o grande Outro. A relação - como apontou Lacan a partir do aforismo "a relação sexual não existe" - entre um sujeito e seu semelhante não existe, ela é sempre não toda, marcada pelo inevitável mal-entendido e pelo equívoco. "O sujeito é dividido entre o que quer dizer e o que pode dizer (...)". A linguagem condiciona o enunciado a ser sempre parcial em relação à enunciação, e disso decorre que a palavra expressa por um sujeito jamais será equivalente à palavra escutada pelo outro. A fala é endereçada a um suposto saber, a alguém suposto que não equivale ao interlocutor, e é animada por uma verdade que é sempre inconsciente. Aquele que enuncia um dizer, o agente do discurso, "não é senão um
} 
sujeito que não quer comparecer; o sujeito encontra aí um grande aliado, que lhe oferece os meios de não se arriscar. O sujeito contemporâneo se oferece ao apetite dos discursos da ciência e do capitalismo com toda sua sede de apagamento.

No laço social se vê firmado o pacto entre o sujeito e a cultura, que demanda renúncia de um lado (o que sem dúvida produz mal-estar), mas, por outro lado, concede aos homens uma (certa) liberdade de circulação e de escolha. Em relação a essa liberdade, no entanto, vivem os homens uma profunda ambiguidade: ao mesmo tempo que a aspiram, a temem.

Esses laços sociais sofrem modalizações de acordo com o mal-estar de seu tempo: podemos dizer que a ambição de exclusão da enunciação seja a grande marca do laço social contemporâneo. Ocorre uma tentativa de subversão da estrutura ternária do laço social, intentando instaurar uma estrutura binária, na qual não haveria referência a um terceiro, ao campo da linguagem, que é a instância que confere legitimidade e que enlaça os sujeitos a um campo comum. No entanto, mesmo os regimes mais totalitários, no limite, não conseguem evitar que isso, que é tão insistentemente banido do laço social, retorne: o sujeito responde com seu sintoma, e o sintoma do sujeito impõe ao socius uma questão.

Na leitura de Hannah Arendt (1958), essa não referência ao campo simbólico corresponde à já citada perda do senso comum. Sem a tradição, que representa um saber referencial capaz de produzir filiação, somos conduzidos ao que ela chamou de "perda em mundo". O totalitarismo vivido no século XX, cujo paradigma são os campos de concentração, marcará o homem contemporâneo de um modo singular: tornará possível a ele alijar-se da experiência por um movimento de negação de sua capacidade de pensar e de julgar. Anne-Marie Roviello (apud LEBRUN, 2004) afirmará, a respeito do entendimento de Hannah Arendt sobre a ideologia totalitária, que o traço distintivo desse pensamento não é o seu caráter mentiroso, mas sim a sua capacidade de perverter os limites do pensamento e da ação por uma imposição de sua própria lógica ao real.

semblante de agente", que é sobredeterminado por uma verdade inconsciente. E para não deixar dúvidas a respeito da "não-relação sexual", Lacan inscreve na estrutura do discurso um símbolo que marca a nãopassagem do lugar da produção para o lugar da verdade: a comunicação jamais se completa (VOLTOLINI, comunicação verbal). 
Arendt encontrará, na figura medíocre e banal de Eichmann, um funcionário obediente da exterminação, capaz de corresponder de um modo espantosamente eficiente àquilo que lhe era demandado dentro do sistema em que se encontrava, o paradigma do asujeito do sistema totalitário: o a-sujeito é o sujeito que "se demitiu de sua posição de sujeito porque se demitiu de sua faculdade de julgar (...) um sujeito que se demite de sua enunciação e se contenta em ser congruente com os enunciados aos quais consentiu em se sujeitar" (LEBRUN, 2004, p. 72).

A maior impostura de Eichmann, que equivale à impostura de todo o delírio nazista, foi a de perpetrar um crime contra a humanidade com ares de quem não fazia nada mais do que sua obrigação. A banalidade do mal, apontada por Arendt, diz respeito a essa normalidade alcançada a despeito de toda a abolição da razão.

Corroborando com esta leitura, Elizabeth Roudinesco afirmará: "No universo nazista, tudo parece coerente, correto, lógico, apropriado, ordeiro e racional. Em nome da ciência mais elaborada e com uma ajuda das mais modernas, instaurou-se a serviço de um genocídio a mais impressionante inversão da norma que se possa imaginar (...)" (ROUDINESCO, 2000, p. 124)

Em O mundo sem limites: ensaio para uma clínica psicanalítica do social (2004), Lebrun reconstitui a participação da ciência e do direito no projeto nazista de purificação da raça. Nele ocorre uma manipulação tal das "leis" a ponto de tornar "legal" o extermínio. Nos campos de concentração, o extermínio de judeus, de homossexuais, de deficientes e demais vidas consideradas não mercedoras de serem vividas foram justificados juridicamente. E a ciência foi invocada para endossar essa legitimidade conquistada pela manipulação legal. As experiências realizadas com seres humanos ou a "eutanásia" de crianças deficientes ou pessoas consideradas inválidas não poderiam ser qualificadas como assassinatos dentro do sistema jurídico alemão nazista, porque antes de tomar essas pessoas como objeto de pesquisa ou de uma ação exterminadora, o sistema legal alemão da época preocupou-se em desapossá-las de todos os seus direitos.

Contando com o apoio de quase metade da totalidade dos médicos da época, o projeto de purificação da raça ganhou um "apoio de cunho científico": o regime nazista fez uso da autoridade e do saber médicos para subverter perversamente atos de violência e horror em procedimentos médicos qualificados (Lebrun, 2004), fato que seria inviável fora do contexto legal produzido pelo nazismo. 
J.-P. Lebrun (2004) lembra que não cabe argumentar no sentido de isentar a ciência da responsabilidade que lhe cabe por ter se implicado dessa forma com o projeto de purificação da raça. Não bastam os argumentos que afirmam que a ciência durante o nazismo estava desviada de seu propósito, distante d'A ciência verdadeira, que teria sido abusada e falseada. Segundo o autor, é preciso assumir a posição de pensar de que modo o "sistema totalitário nazista é tributário do movimento inaugurado pelas modificações introduzidas no discurso social com o surgimento da ciência moderna" (LEBRUN, 2004, p. 69) e, para além do nazismo, de que modo a aversão à enunciação (cuja versão paradigmática são os campos de concentração) se faz presente no laço social contemporâneo.

Hoje, em decorrência da extrapolação das fronteiras do campo científico do discurso cientificista, e da pregnância do discurso do capitalista no mundo contemporâneo, essa ação abusiva e totalitária sobre o sujeito encontrou outras formas de expressão nos estados modernos, que precisam "legislar sobre a polivalência de gozos que afetam aos corpos falantes" de um modo que "valha para todos, excluindo as diferenças" (NAJLES, 2008, p. 58 - tradução nossa).

Por efeito dessa ação que pretende "valer para todos" em um mundo globalizado, uma categoria imaginária é forjada com a pretensão de abarcar a totalidade dos homens: a categoria dos "consumidores". No espaço global, o poder do Estado foi substituído pelo poder do mercado. Regidos pela lógica do mercado, somos todos consumidores e, enquanto consumidores, somos todos crianças (NAJLES, 2008). A criança generalizada $^{13}$, de Lacan, expressa a tomada da criança pelo outro como objeto que, em uma só medida, lhe rouba a palavra e a desresponsabiliza (ibidem).

Todos consumidores é a marca da indiferença que caracteriza a política contemporânea. Nela a distinção entre o público e o privado não mais se sustenta, os ideais não cumprem uma função de baliza para o sujeito e ingressamos em um plano no qual impera o gozo.

O consumidor é uma figura do a-sujeito do sistema totalitário que, agarrado a uma posição de gozo, se oferece como instrumento, renunciando à posição de desejo, sempre

\footnotetext{
${ }^{13}$ A noção de criança generalizada foi introduzida por Lacan em “Alocução sobre as Psicoses" (1968). Esta noção "aponta exatamente para essa condição de objeto que a criança sustenta na fantasia de outro, e, evidentemente, em tal posição, ela é sem responsabilidade" (Fragelli, 2011, p. 41).
} 
tão instável e tão incerta, em prol da estabilidade e da certeza oferecidas pela fixidez do lugar de objeto.

O mundo global e do consumo produzem um impacto na vida social de nosso tempo e sem dúvida em nosso educar. A educação perpassada por essa lógica do gozo se vê pervertida, pois não é possível educar sem desejo e sem enquadramento.

\subsection{Da paixão pela instrumentalidade}

Em um ensaio sobre o impacto da técnica sobre o sujeito e sobre o modo como o laço social vem sendo modalizado com base nessa influência ${ }^{14}$, o psicanalista Contardo Calligaris propõe designar por "paixão pela instrumentalidade" o fascínio neurótico por seu apagamento. $\mathrm{O}$ sujeito neurótico encontra na técnica uma forma de se esquivar de sua angústia por meio de um ausentar-se.

O sujeito neurótico se empenha em banalizar ou contradizer o conteúdo do aforismo "a relação sexual não existe": a não-relação sexual, a castração, o impossível são formas diferentes de designar algo muito próximo: ao sujeito não cabe o absoluto, seu destino não é a plenitude; ao contrário, sua vocação é a ignorância e a perplexidade.

Com o termo "paixão pela instrumentalidade" o autor propõe que o sujeito aceita se fazer instrumento de um saber que lhe é exterior, porque isso apazigua sua dor de existir.

Esse saber se constitui como um semblante de saber paterno ${ }^{15}$, que se oferece ao coletivo como um saber, ao mesmo tempo, acessível e compartilhável. O conteúdo desse saber é indiferente, bastando que ele afete a todos de um modo uniforme.

Vê-se como tal semblante de saber só poderia estar a serviço de uma ambição totalitária, posto almejar-se absoluto e por tratar todo aquele que não o reconhece como tal como uma ameaça a seu domínio. Um domínio, como vimos, que demanda um assujeitamento absoluto a seus termos, oferecendo em troca o benefício de ser parte de uma engrenagem. Em outras palavras, oferece-se ao sujeito a ilusão de que ele não é

\footnotetext{
${ }^{14}$ Calligaris, C. A sedução totalitária. In Clínica do social: ensaios. São Paulo, Escuta, 1991.

${ }^{15} \mathrm{O}$ saber do qual a psicanálise fala é necessariamente inconsciente, inacessível e não compartilhável. O semblante de saber do qual Calligaris fala aqui é uma per-version de um saber.
} 
responsável pelos seus atos, inclusive de que seus atos não se constituem exatamente como escolhas, e que é possível pendurar essa conta sob outra tutela, que não a sua.

"Apesar de ter escolhido um exemplo no fundo do horror ${ }^{16}$, considero que a paixão pela instrumentalidade é o ordinário da vida social, a sua inércia natural" (CALLIGARIS, 1991, p. 115, grifos nossos).

O neurótico se oferece como instrumento da máquina social: o preço a pagar por isso é alto, paga-se com sua própria subjetividade, mas o retorno o recompensa, a dessubjetivação vem acompanhada de uma anestesia (mórbida) do pulsar do desejo, o que promove um apaziguamento da angústia.

Observamos, todavia, um efeito no mínimo instigante: esse sujeito, preso e eclipsado em um tempo presente, esvaziado de sentido, não chega a sofrer o suficiente para encontrar motivos e forças para tentar romper com o vício do mandato "gozar a todo custo" do discurso capitalista (LAURENT, 2007).

Como desestabilizar esse discurso tão "eficiente" e tão atraente, que promete não deixar nada a desejar? Apesar de tudo, o sujeito está aliviado (ibidem). É por isso que Eric Laurent o chama de "sujeito light", mas, como ele bem nos alerta, "essa leveza não é sustentável”!

Sem a densidade e a complexidade que lhe são devidas, o sujeito light não sustenta uma posição de desejo na relação com o Outro, aceitando mais facilmente a alienação concernente ao lugar (discursivo) de objeto. O sujeito, desimplicado de seu desejo, mostra-se indiferente quanto a seu não saber e exime-se de sua responsabilidade.

\subsection{A impostura do não-limite na sociedade capitalista}

O capitalismo institui como valor o acúmulo de bens. Marca um divisor de águas entre o homem do iluminismo, cujo valor se estimava do lado do ser, e o homem do capitalismo, cujo valor se estima do lado do ter. Do lado do ser, o homem era dotado de incertezas, e barrado por limites que se impunham a ele; do lado do ter, vive a ilusão da certeza (para a falta de um objeto, fabrica-se um objeto sob medida) e está submetido ao que designamos como uma impostura do não-limite. Impostura posto que se oferece de

\footnotetext{
${ }^{16} \mathrm{O}$ artigo recupera o julgamento de Albert Speer, alto funcionário nazista.
} 
forma ardilosa como verdade, como se fora possível ao homem subverter a lógica pulsional para a qual desde sempre o objeto esteve perdido.

Na sociedade de consumo, os objetos nos seduzem com sua promessa de nos saciar plenamente. Eles asseveram uma completude e uma felicidade que jamais poderão ser garantidas. Os objetos contemporâneos se prestam ao consumo, são marcados pelo efêmero, seu destino é o descarte, é ser dejeto. No entanto, são marcados por um paradoxo: se de um lado, portam a promessa de completude, incitando a uma desmesura, a um excesso, por outro, terminam por exacerbar a falta e o desamparo nos homens.

A sociedade de consumo e o sujeito light são marcas do contemporâneo, de um mundo sobre o qual o discurso capitalista exerce uma influência hegemônica. Não é à toa que Lacan coloca esse discurso à parte dos outros quatro discursos descritos por ele, a saber, o do mestre, do universitário, do analista e da histérica. Os quatro discursos têm na sua estrutura os mesmos elementos (o agente, o outro, a produção e a verdade), que mudam de posição em um quarto de giro, no sentido horário, de cada elemento. Este aspecto de circularidade é muito importante, porque Lacan demonstra todo o trabalho que pode acontecer com base no manejo dos discursos, visando a uma mudança da posição do sujeito.

Os quatro discursos revelam uma fratura baseada na inscrição do impossível entre o lugar da produção e o da verdade. Dessa forma, Lacan explicita a verdade como causa, como lugar de enunciação do sujeito, lugar que o sujeito não pode acessar, mas desde o qual ele próprio é acessado. O sujeito não percebe a ação da verdade sobre sua produção, apesar de ela ser sobredeterminada desde esse lugar. Todos os quatro discursos traduzem a marca da não-complementariedade, da não relação sexual.

O discurso do capitalista, no entanto, não porta a inscrição do impossível, essta barreira que impede um círculo vicioso dentro dos outros quatro discursos. Além disso, dentro do discurso do capitalista, as setas que indicam uma direção de leitura e de encadeamento dos lugares mudam de direção, reforçando o lugar do agente em detrimento do lugar da verdade. A própria estrutura desse discurso subverte o impossível, tal como na perversão: o perverso reconhece a castração, mas se põe como exceção. 
Este fato corrobora a leitura de Elizabeth Roudinesco acerca da sociedade contemporânea como sociedade depressiva. A esse respeito, a autora esclarece: “ [...] as sociedades democráticas do fim do século XX deixaram de privilegiar o conflito como núcleo normativo da formação subjetiva” (ROUDINESCO, 2000, p. 19).

O homem atual sabe da existência do inconsciente, mas, mesmo assim, insiste em ignorá-lo, prefere tratar a alma como coisa, opta por uma existência sem afeto, sem paixões. A tentativa de fazer do impossível estrutural em impossibilidade contingente promove um aniquilamento do desejo.

O discurso do capitalista nada-quer-saber do desejo, da verdade; ele apenas quer confirmar a ilusão que o anima, de que o impossível não é estrutural, mas sim conjectural.

Ao descaracterizar a ideia de sociedade, sobrepondo a ela a de mercado, configura-se um discurso que se coloca à margem da lei, porque as leis dos homens são reguladoras do nosso encontro com o outro na cena social. O mercado, entretanto, sendo uma entidade invisível, impalpável e intangível, não está submetido a essas mesmas regulações. O discurso do capitalista não promove um laço social; pelo contrário, ele promove segregação.

Isso é fundamental, posto vivermos em um tempo marcado pela política da inclusão. $\mathrm{O}$ discurso manifesto da inclusão pleiteia a diversidade como ideal; no entanto, o que se vê nas escolas é o acirramento da intolerância diante do diferente.

\subsection{Unheimlich ${ }^{17}$ e Intolerância}

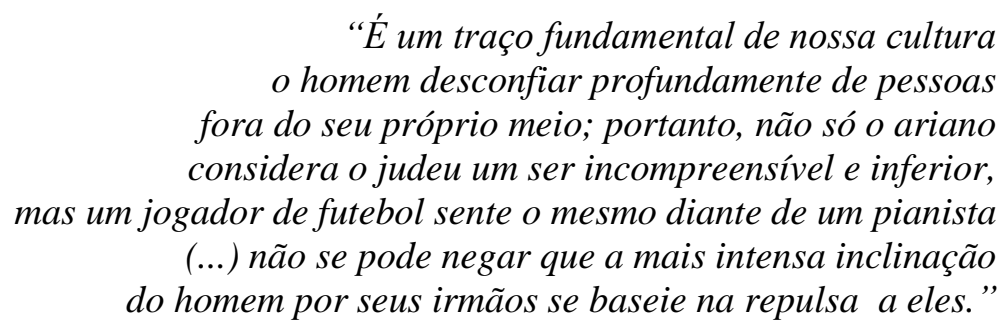

(Robert Musil)

A palavra estrangeiro vem do latim extraneus, que quer dizer o que vem de fora; remete a não familiar, fora do comum, incompreensível.

\footnotetext{
${ }^{17}$ Em alemão, significa 'um estranho mais que estranho' (tradução livre). A acepção dessa palavra será mais bem trabalhada ao longo desta seção.
} 
Diante do estrangeiro não ficamos incólumes: o estranho e o não familiar que ele porta nos mobiliza necessariamente. Podemos nos sentir convocados, tensionados numa certa direção; somos convidados a sair do nosso lugar comum, em prol de um lugar compartilhável: o estrangeiro pode nos mobilizar no sentido de uma tentativa de aproximação com o outro.

Mas o estrangeiro, muito mais comumente, ganha representações de inimigo: perante o desconhecido, tendemos ao medo ou à intolerância. Contrariando a interpretação corrente, que determina como estranho aquilo que não é familiar, a interpretação freudiana o apontará como "um tipo de horror que remete àquilo que é desde há muito tempo íntimo e velho conhecido" ${ }^{\prime 18}$. Nem tudo que é novo adquire esse estatuto de estranho para o sujeito; no entanto, Freud afirmará que acrescido de um certo novo elemento, o não familiar pode facilmente ser transmutado em estranho.

Ao recuperar as acepções linguísticas das palavras Unheimlich e Heimlich, Freud se depara com uma ambivalência aí contida: Heimlich comporta, além do sentido corrente (aquilo que é familiar, doméstico, conhecido, protegido dos olhos de estranhos, livre da influência de fantasmas), uma noção que coincide com o seu oposto (Unheimlich): aquilo que é obscuro e inacessível ao conhecimento.

"Unheimlich é o nome de tudo que deveria ter permanecido secreto e oculto, mas que veio à tona" ${ }^{19 "}$ (SCHELLING apud FREUD, 1919). Esta citação de Schelling remete Freud à ideia de que o sentimento de que alguma coisa é amedrontadora ( $\ddot{n}$ gstliche) diz respeito ao retorno de algo que havia sido recalcado. Sendo assim: "O estrangeiro é parte da vida psíquica que se furtou à consciência” (KOLTAI, 2000, p. 85).

$\mathrm{O}$ estrangeiro lembra ao sujeito de sua própria divisão: sou, ali onde não penso. $\mathrm{O}$ sujeito é animado por uma verdade sempre inconsciente, que lhe escapa, e que lhe assujeita. $\mathrm{O}$ estrangeiro remete aos piores humores que engendram a subjetividade, com os quais o sujeito tende a não querer assumir nenhum tipo de afinidade. E é por isso que, ao reconhecer no outro o húmus deste parentesco, o sujeito o inocula, tendendo a depositar sobre ele todo o seu horror.

Isso justifica por que, diante do estrangeiro, o homem tende à intolerância: ele parte de uma relação ambígua e intransigente com a sua própria divisão. E essa intransigência

\footnotetext{
${ }^{18}$ Nossa tradução do original: "das Unheimlich sei jene Art des Schreckhaften, welche auf das Altbekannte, Längstvertraute zurückgeht" (Freud, 1919, p. 214).

${ }^{19}$ No original: "Unheimlich nennt man Alles, was im Geheimnis, im Verborgnen ... bleiben sollte und hervorgetreten ist".
} 
pode encontrar tradução no acontecimento social, seja em movimentos sociais extremos, como o racismo ou de regimes totalitários de governo, como em versões mais "politicamente corretas" dessa intolerância, posto que encontram nos discursos da ciência e da técnica, discursos esses altamente valorizados em nosso tempo, substrato para uma ação que vem sendo exercida sobre esse estrangeiro no mundo contemporâneo, que é uma ação segregatória.

Um exemplo disso é a incidência do diagnóstico nos campos "psi” e da educação. Se na medicina o diagnóstico pode ser, eventualmente, entendido como o ponto de partida para tomadas de decisão em relação ao procedimento a ser adotado, fora desse contexto, porém, o diagnóstico mais fecha um caminho do que abre possibilidades, pois oferece um mesmo nome para situações que são sempre particulares, posto serem motivadas pela experiência singular de cada sujeito. Ele se pauta pelo fenômeno e desconsidera a verdade inconsciente que anima e modula o sintoma.

Do ponto de vista da psicanálise, por exemplo, não existe "A" hiperatividade, existem crianças que se agitam por razões que só se revelam na escuta individual de cada caso. O diagnóstico faz decorrer um procedimento protocolar, que define ações que independem das particularidades de cada situação. Desconsidera o sujeito por trás do sintoma, não levando em consideração as motivações que impedem uma parada e que aprisionam o sujeito em uma agitação corporal perturbadora.

Ao recusar relevar a subjetividade, o diagnóstico rechaça o estranho, que se faz presente na manifestação singular de cada sujeito. Ao estabelecer "A" verdade sobre o sujeito, produz desimplicação nos sujeitos envolvidos com a criança e na própria criança. Ao acreditarem que esta se define por aquilo que dita o diagnóstico, professores e pais deixam de apostar que a criança possa responder de um modo surpreendente; sendo assim, nada mais se espera da criança além de que esta confirme aquilo que já é sabido. E a criança passa a responder desde esse lugar, identificada a esse lugar de impotência.

O diagnóstico silencia a aposta e elimina a esperança. Nas escolas, tem se tornado extremamente comum, conduzindo a um excesso de medicalização, que, ao ignorar o sujeito e seu sintoma, simplesmente faz contenção. A medicação só pode ser interessante para o sujeito se estiver no lugar de auxiliar um tratamento que contribua para que a criança simbolize esse resto de corpo que insiste em não se deixar conter pelo simbólico. Caso contrário, a medicação se presta exclusivamente à manutenção da ordem social, sendo apenas signatária dos mandatos de eficiência e sucesso que marcam 
a sociedade contemporânea. Para romper com esse círculo vicioso, é preciso relativizar o absoluto e questionar as certezas que sustentam essa situação. Para uma criança recuperar as rédeas de seu próprio destino é preciso, acima de tudo, resgatar esse estranho indesejável, o desejo.

\subsection{Da psicologização do cotidiano escolar}

A entrada do discurso "psi” nas instâncias educativas se dá pela fragilização da família como detentora de um saber sobre a criança e sobre como educá-la. Esse fenômeno acontece em resposta a um declínio da função paterna nos tempos modernos. E a educação, que está indelevelmente articulada à questão da lei, padecendo da sustentação simbólica que lhe é devida, passa a se valer ortopedicamente de ilusões que sustentam posições frágeis e equivocadas. Frágeis por não comportarem o peso da necessária responsabilidade presente no ato de fazer de um neófito um sujeito pertencente a uma cultura. E equivocadas posto que balizadas por uma representação da criança feita de puro estofo imaginário: a criança vista pelo adulto contemporâneo especulariza aquilo que a ele falta e lhe acena com a possibilidade de realizar seus sonhos fracassados.

Além disso, apartada de seu campo de tradição, a escola deixou de poder lançar teses e hipóteses, desde seu lugar de saber, sobre sua própria práxis. Desprovida de uma bússola ética que possa organizar seu saber dentro de seu campo de atuação, passou a demandar de outros campos do conhecimento como conduzir sua prática de modo a garantir que não ocorressem tropeços nem fraturas.

A psicologia, nascida em meados do século XIX, de braços dados com a ideologia do sucesso e da produção, foi animada desde o início pelo desejo de construir um saber tal sobre o funcionamento psíquico que permitisse um controle absoluto das ações humanas, retificando seus lapsos e aperfeiçoando suas imperfeições. O projeto da psicologia científica era (e ainda o é) o de oferecer aos homens a chave para a sua emancipação e para seu aprimoramento. Para cumprir com tal ambição, tomou de empréstimo modelos epistemológicos das ciências naturais, mais especificamente da biologia, de onde extraiu as noções de organismo, estímulo e adaptação, e das ciências exatas, de onde vieram todos os instrumentos de observação e mensuração (PATTO, 1984). 
Fica evidente o pacto entre a ambição cientificista da psicologia nascente e a frágil pedagogia do início do século XX não poderia ter como resultado nada menos do que uma crise.

"Sob a influência da psicologia moderna e dos princípios do pragmatismo, a pedagogia transformou-se em uma ciência do ensino em geral a ponto de se emancipar inteiramente da matéria efetiva a ser ensinada" (ARENDT, 1997, p. 231).

Neste ponto, a autora critica as proposições escolanovistas e sua inspiração pragmática forjadas pelas críticas dirigidas indistintamente à escola tradicional e sustentadas por um ideário biopsicodesenvolvimentista, que argumentava em prol de um ensino sem conteúdo determinado. "Aprender a aprender" era o corolário dessa ideologia, que apostava em um organismo em desenvolvimento, cujas aprendizagens eram apenas decorrência do êxito de um desenrolar da natureza. $\mathrm{O}$ adulto devia intervir o menos possível para não corromper o desenvolvimento "natural" da criança. O professor deveria limitar-se a estimular e orientar a aprendizagem, "cuja iniciativa principal caberia aos próprios alunos" (SAVIANI, 2001, p. 9). E, acima de tudo, deveria ser um profissional "capaz de ensinar qualquer coisa" (ARENDT, 1997, p. 231).

Disso decorreu uma deturpação na formação dos professores, que deixaram de investir em formações específicas, produzindo como resultado um professor que sabe apenas um pouco mais do que seus alunos. Sobre isso, salienta Arendt: "o que daqui decorre é que, não somente os alunos são abandonados aos seus próprios meios, como ao professor é retirada a fonte mais legítima da sua autoridade" (ibidem).

$\mathrm{O}$ escolanovismo ${ }^{20}$, apesar de não ter encontrado meios de se firmar como opção dentro do cenário dos sistemas escolares, teve seu ideário amplamente difundido no meio

\footnotetext{
${ }^{20}$ Excertos do Manifesto dos Pioneiros da Educação Nova, 1932: “O desenvolvimento das ciências lançou as bases das doutrinas da nova educação, ajustando à finalidade fundamental e aos ideais que ela deve prosseguir os processos apropriados para realizá-los. A extensão e a riqueza, que atualmente alcança por toda a parte o estudo científico e experimental da educação, a libertaram do empirismo, dando-lhe um caráter e um espírito nitidamente científico (...) A escola, vista desse ângulo novo que nos dá o conceito funcional da educação, deve oferecer à criança um meio vivo e natural, 'favorável ao intercâmbio de reações e experiências', em que ela, vivendo a sua vida própria, generosa e bela de criança, seja levada 'ao trabalho e à ação por meios naturais que a vida suscita quando o trabalho e a ação convém aos seus interesses e às suas necessidades'. Nessa nova concepção da escola, que é uma reação contra as tendências exclusivamente passivas, intelectualistas e verbalistas da escola tradicional, a atividade, que está na base de todos os seus trabalhos, é a atividade espontânea, alegre e fecunda, dirigida à satisfação das necessidades do próprio indivíduo. Na verdadeira educação funcional deve estar, pois, sempre presente, como elemento essencial e inerente à sua própria natureza (...) a adaptação da atividade educativa às necessidades psicobiológicas do momento. O que distingue da escola tradicional a escola nova não é, de fato, a predominância dos trabalhos de base manual e corporal, mas a presença, em todas as suas atividades, do fator psicobiológico do interesse, que é a primeira condição
} 
educacional, influenciando a rede de ensino oficial, supostamente organizada na forma tradicional $^{21}$ (SAVIANI, 2001). Sua influência produziu uma báscula de uma “pedagogia de inspiração filosófica centrada na ciência da lógica para uma pedagogia de inspiração experimental baseada principalmente nas contribuições da biologia e da psicologia" (ibidem, p. 9).

Lida pela psicanálise, a renúncia pedagógica de uma posição de saber em relação a sua prática, em prol da tutela conquistada por meio de sua subordinação a saberes importados de outros campos do conhecimento, produziu uma desimplicação dos sujeitos aí envolvidos (alunos, professores e pais). A desvalorização do próprio saber produz desresponsabilização: o sujeito desimplicado de seu ato busca externamente culpados para responder a seus próprios impasses.

Tudo isso é efeito da entrada impetuosa, com efeitos hegemonizantes, do discurso da psicologia no campo da pedagogia, que conduz a um grande gesto de renúncia (LAJONQUIÈRE, 2009, p. 29). E é em reconhecimento a este fato que Leandro de Lajonquiére cunha o já bastante divulgado “discurso (psico)pedagógico hegemônico”.

Diz ele: “O discurso (psico)pedagógico hegemônico repousa na ilusão de que saber é poder, ou seja, que conhecendo as leis da aprendizagem o pedagogo detém o poder de calcular os efeitos dos métodos que coloca em ação" (LAJONQUIÈRE, 1992, p. 15).

Lajonquière opta por colocar entre parênteses o termo (psico), condensando aí diversas leituras (psico)pedagógicas que se arrogam detentoras de uma verdade sobre a prática pedagógica. Entre elas, cita não apenas o behaviorismo, mas também o cognitivismo (que supõe uma controlabilidade das faculdades mentais), a psicologia do ego e certas leituras da teoria piagetiana, que se sustentam sobre uma aposta de que esta seja capaz de oferecer meios para tornar mais científica a pedagogia (ibidem, p. 15).

de uma atividade espontânea e o estímulo constante ao educando. (...) É certo que, deslocando-se por esta forma, para a criança e para os seus interesses, móveis e transitórios, a fonte de inspiração das atividades escolares, quebra-se a ordem que apresentavam os programas tradicionais, do ponto de vista da lógica formal dos adultos, para os pôr de acordo com a "lógica psicológica", isto é, com a lógica que se baseia na natureza e no funcionamento do espírito infantil. (...) A escola nova, que tem de obedecer a esta lei, deve ser reorganizada de maneira que o trabalho seja seu elemento formador, favorecendo a expansão das energias criadoras do educando, procurando estimular-lhe o próprio esforço como o elemento mais eficiente em sua educação e preparando-o, com o trabalho em grupos e todas as atividades pedagógicas e sociais, para fazê-lo penetrar na corrente do progresso material e espiritual da sociedade de que proveio e em que vai viver e lutar" (grifos nossos).

${ }^{21} \mathrm{O}$ ensino tradicional é caracterizado por uma centralidade na figura do professor, de quem se espera uma formação sólida e uma posição de autoridade em relação aos alunos, de quem, por sua vez, se supõe uma posição de disciplina e empenho em sala de aula. 
No discurso (psico)pedagógico, podemos distinguir três pressupostos que contribuem para a composição de um cenário bastante confuso. O primeiro deles está na base das psicologias do desenvolvimento e sustenta que nada se interpõe entre o sujeito e o objeto de conhecimento. Sendo assim, pressupõe um organismo portador de todas as condições necessárias para sua maturação, seja ela afetiva ou neurológica. O segundo pressuposto aposta na intermediação psicológica passível de controle, conduzindo às teorias psicológicas das aprendizagens, cuja inspiração é behaviorista. Já o terceiro pressuposto considera o psiquismo um mero epifenômeno do organismo, e acredita que a explicação da aprendizagem é dada pela lógica maturacionista do organismo. Esta postura conduz à concepção de que os acometimentos orgânicos se impõem como causa das fraturas no aprender e aproximam a prática (psico)pedagógica de uma reabilitação ou de "mero apoio psicológico" (LAJONQUIÈRE, 1992).

Esses três pressupostos levam a uma segregação do lugar da enunciação do sujeito, e conduzem à ilusão de controle absoluto. Em resposta a isso, a psicanálise dirá que não é o organismo que causa o sujeito (ele apenas lhe impõe limites), que o corpo é regido pela ordem significante e que o desejo não é passível de controle. 


\section{II - Do sintoma social}

\section{Do sintoma e do social}

Não há clínica do sujeito sem clínica da civilização.

(Jacques-Alain Miller)

Antes de nos dedicarmos à discussão do sintoma social, entendemos ser relevante discorrermos brevemente sobre a aproximação dos conceitos de sintoma e social, que se apresentam aparentemente como díspares. A suposta contradição diz respeito ao fato de o sintoma estar referido ao campo do sujeito, a uma construção que não poderia ser mais singular, já que está forjada de um modo extremamente particular, marcando um modo próprio de gozar do sujeito, que não é repetível nem compartilhável; já o social, é concernente ao campo da coletividade, àquilo que é da ordem do bem público, e que, portanto, deve ser compartilhável entre os homens. Do ponto de vista freudiano, o social se refere àquilo que confere universalidade aos sujeitos, ao impor a todos um mal-estar. Como se vê, esses conceitos lidos pela psicanálise se embricam de tal modo que se torna impossível não violar as fronteiras entre o que é da ordem do particular e do coletivo.

No próprio interior do conceito de sintoma, o social está presente. A psicanálise entende o sintoma como uma resposta arquitetada pelo sujeito diante de seu encontro com o campo do Outro e ao mal-estar que daí decorre. E será no entorno do sintoma que o sujeito se organizará, domesticando pulsões indomáveis e se articulando ao socius. O sintoma concede préstimos tanto às exigências de satisfação pulsionais quanto às reivindicações sociais, construindo um lugar possível para o sujeito: o contexto social não é apenas pano de fundo do sintoma subjetivo, também faz parte de sua própria trama.

A esse respeito, nos dirá Vorcaro: "A produção do sintoma individual se alimenta do imaginário social e é a partir dele que faz a sua invenção" (VORCARO, 2004, p. 63).

Freud já apontava, em sua obra, que não existe uma psicanálise que se ocupa do individual e outra, do coletivo. A singularidade é efeito do encontro do sujeito com seu semelhante e com a rede discursiva, em torno da qual o social se organiza. Todo sintoma excede a árvore genealógica de cada um (CALLIGARIS, 1991), trazendo as marcas dos discursos que vigoram em seu tempo. 
No esquema $\mathrm{L}^{22}$, Lacan se ocupa justamente de demonstrar que a subjetividade se constitui tanto a partir da relação do sujeito com seu semelhante, como de sua relação com o grande Outro. A subjetividade, demonstra-nos Lacan, está intimamente ligada a essa coletividade.

Desde essa perspectiva, portanto, a aproximação entre estes dois conceitos, sintoma e social, não é descabida, mas sim coerente com certo modo de pensar o sujeito, que torna imprescindível não desconsiderar aquilo que o sobredetermina. Isso tem como decorrência o imperativo ético de se "inventar uma prática discursiva no social" (CALLIGARIS, 1991, p. 13) capaz de abalar as certezas totalitárias que impedem que os homens se reinventem.

Não se trata apenas, como reafirmou Calligaris na apresentação dos intentos do grupo o "Sexto Lobo", no livro Clinica do social (1991), de "constituir uma doutrina psicanalítica sobre o sintoma social", tampouco de "uma promessa de consertos ou pacificação". O impossível, sabemos, não tem conserto. Trata-se, sim, de "inventar uma prática discursiva no social" capaz de expor as contradições que animam o socius, produzindo pequenos abalos nos alicerces rígidos que estruturam os discursos sociais, visando a fazer frente à tendência que os discursos têm de se tornarem hegemônicos.

\section{Da definição de sintoma social}

A construção da categoria de sintoma social é relativamente recente e ainda controversa no meio psicanalítico. Das primeiras aparições na obra de Lacan até os desdobramentos que se sucederam, essa noção passou por contextos muito diferentes entre si e ganhou contornos muito diversos.

Para fins de análise do contexto educativo no mundo contemporâneo, objeto de estudo desta dissertação, fizemos uso da noção de sintoma social proposta pelo psicanalista Charles Melman a propósito do estudo das toxicomanias. Tal proposição produz uma inflexão na ideia original de Lacan a respeito dessa mesma noção. Para compreendermos o contexto dessa elaboração teórica, entendemos ser importante

${ }^{22} \mathrm{O}$ esquema L demonstra o movimento dialético baseado no qual o sujeito se constitui: o reconhecimento de si através do outro, e do outro através de si. Evidencia uma característica fundamental da comunicação humana: não há uma relação direta, tampouco completa, entre o sujeito e o grande Outro; o eixo aa' (imaginário) se interpõe entre $\mathrm{S}$ e $\mathrm{A}$, produzindo uma interferência na palavra que é endereçada. No entanto, há algo que vem do campo do Outro, que escapa ao $\mathrm{S}$, e que incide de modo direto sobre a (moi) (DOR, 1989) 
retomarmos as ideias de Lacan sobre esse assunto antes de nos debruçarmos sobre a proposta de Melman. Para tanto, guiaremo-nos pela organização feita por Sidi Askofaré sobre o tema em seu artigo "O sintoma social” (1997).

Foi o encontro da obra de Lacan com Marx que permitiu a emergência da noção de sintoma social como aquilo que representa o retorno da verdade na falha de um saber. O sintoma marca a oposição entre saber e verdade, e sua precipitação traz desordem, fazendo irromper na cadeia da significação um não sentido.

Lacan afirma, em $1966^{23}$, que foi Marx o inventor do sintoma: "É difícil não ver introduzida desde antes da psicanálise uma dimensão que se poderia dizer do sintoma, que se articula pelo fato de que representa o retorno da verdade como tal na falha de um saber" (LACAN, 1966 apud ASKOFARÉ, 1997, p.166).

O sintoma não diz respeito a uma falha na representação, mas se trata de uma verdade "que vem perturbar a bela ordem" (ibidem, P. 166).

Para Lacan, a noção de sintoma é signatária de sua elaboração sobre a noção de verdade, desenvolvida em sua leitura da crítica feita por $\operatorname{Marx}^{24}$ a Hegel. Marx irá atribuir a Hegel mais a produção de um corpo político para fundamentar sua lógica do que a produção de uma elaboração da lógica do corpo político (ASKOFARÉ, 1997). A crítica de Marx a Hegel questiona a verdade de sua proposição, que coloca a razão como protagonista da história. Para Marx, são as ideias ou as ilusões que ocupam um lugar de dominação no mundo, e não a razão. A esste movimento engendrado pela crítica de Marx, Lacan nomeou "o retorno da questão da verdade".

"A invenção marxiana do sintoma pode ser diretamente referida à posição metodológica de Marx enquanto propõe um procedimento teórico de 'crítica da ideologia', que é propriamente falando, sintomal" (ASKOFARÉ, 1997, p. 172).

A proposta de Marx nada mais é do que tomar os dogmas como "signos a decifrar, quer dizer como sintomas" (ibidem, p. 172). Vê-se como tal elaboração se articula ao pensamento de Lacan sobre o sintoma, para quem esse conceito marca um plano de discordâncias entre o real e a ideologia (LACAN, 1967 apud ASKOFARÉ, 1997).

É importante atentar para o fato de que neste tempo de sua elaboração teórica sobre o sintoma, Lacan ainda o está tomando em sua dimensão de metáfora, e em um plano no

\footnotetext{
${ }^{23}$ Em um texto de abertura dos Escritos.

${ }^{24} \mathrm{Em}$ : "Crítica do direito político hegeliano", de 1843.
} 
qual é possível reconhecer entre o recalque e o desconhecido - que está na essência da ilusão ideológica - uma congruência: o recalque instaura a dimensão da verdade, que se mantém desconhecida à espera de seu desvelamento.

A partir de 1970, e de sua teorização dos discursos, a formulação sobre o sintoma ganhará novos contornos. Lacan aproximará o sintoma do discurso do mestre, no sentido de que faz objeção ao desejo do mestre de que as coisas funcionem.

Para Lacan, há uma equivalência do inconsciente e o discurso do mestre: o inconsciente é "um saber que não pensa, nem calcula, nem julga", é "o trabalhador ideal” (LACAN, apud ASKOFARÉ, 1997, P. 175). É esta relação de equivalência que embasará a formulação lacaniana da greve como paradigma do sintoma, como aquilo que sinaliza $o$ que não vai bem no campo do real. A greve é ao mesmo tempo "entrada em pane" e “sinal de um profundo respeito pelo laço social” (ASKOFARÉ, 1997, p. 175). Ela faz oposição ao desejo do mestre de manter o funcionamento das coisas, bem como faz barra à mais-valia, que é o que faz função de causa do desejo do capitalista.

Askofaré coloca em relevo o fato de Lacan não se referir à noção de sintoma social de outra forma que não seja no singular. Para aquele autor, é preciso distinguir radicalmente o que Lacan chamou de "sintoma social" dos fenômenos sociais, da mesma forma que não se deve tomar esse conceito como um apontamento para uma psicopatologia social, que tenderia a considerar que os discursos dominantes em uma sociedade engendrariam sintomas subjetivos específicos ${ }^{25}$.

Vejamos como isso comparece no texto de Lacan: "Há apenas um único sintoma social: cada indivíduo é realmente um proletário, quer dizer, não há nenhum discurso com que fazer laço social, ou dizendo de outra maneira, semblante" (LACAN, 1975 apud ASKOFARÉ, 1997, p. 177).

Segundo Askofaré, este enunciado faz alusão à história e ao discurso. À história, pela referência à passagem do feudalismo ao capitalismo, descrita por Marx em $O$ capital:

"A ordem econômica capitalista saiu das entranhas da ordem econômica feudal. A dissolução de uma isolou os elementos constitutivos da outra" (MARX, apud ASKOFARÉ, 1997, p. 178).

\footnotetext{
${ }^{25}$ As considerações de Melman sobre esse tema também não vão considerar essa relação mecânica entre um discurso e os sintomas subjetivos. Os discursos hegemônicos criam tendências e "armadilhas", mas não determinam uma resposta, que sempre dependerá de como um sujeito, em particular, se encontra com esse discurso, e como responde a ele.
} 
Essa passagem culminará com o engendramento de uma nova classe, a do proletariado, pelo processo de um despojamento: "Esses liberados não se tornam vendedores deles mesmos senão depois de terem sido despojados de todos os seus meios de produção e de todas as garantias de existência oferecidas pela antiga ordem das coisas" (MARX apud ASKOFARÉ, p. 178).

No Seminário 17, O avesso da psicanálise, Lacan introduz um novo conceito de proletário à luz da teoria dos discursos: o proletário não se define pelas relações de produção, mas sim pelo lugar que este ocupa no discurso. O proletário é aquele que foi despojado da sua função de saber. Seu lugar no social se estabelece como resposta a uma mudança na economia do discurso do mestre, na passagem do mestre antigo para o mestre moderno, que é o capitalista: o escravo antigo detinha um saber que interessava ao seu senhor; já o proletário não detém nenhum saber, ele é pura força de trabalho. $\mathrm{O}$ indivíduo, não o sujeito, equivale ao proletário: ele é desprovido de tudo! Askofaré toma o indivíduo apontado por Lacan como o sujeito completado por seu gozo, do qual nenhum discurso pode fazer semblante. Somos todos proletários porque nossa humanidade se deve ao fato de que não há uma verdade que possa ser dita.

“É esse 'déficit social' que resulta da solidão imanente do gozo, que no ensino de Lacan toma o nome de sintoma social" (ASKOFARÉ, 1997, p. 181).

O sintoma social não deve ser oposto ao sintoma particular. Askofaré sugere tomá-lo na antinomia entre uma teoria geral e outra restrita. Do ponto de vista de uma teoria geral, o sintoma social conota a universalidade da função do sintoma, "como função de exsistência do inconsciente e como efeito no real do simbólico" (ibidem, p. 182). Do lado da teoria restrita, está situado o sintoma particular, que nada mais é do que a “modalização, no nível do sujeito, do universal da função do sintoma” (ibidem).

A preocupação de Askofaré nesse artigo, mais do que contestar o conceito de sintoma social, é o de precisá-lo para evitar um uso corriqueiro e pouco embasado. Daí a ênfase que ele confere ao nó do gozo, à articulação entre simbólico e real. Tal proposição, no entanto, não é incompatível, nem contraditória, com o impacto do imaginário sobre essa questão (VOLTOLINI, 2012, comunicação pessoal).

O desdobramento proposto por Melman e outros psicanalistas da noção de sintoma social se apoia nessa ideia de um aspecto universal do sintoma, que diz respeito ao malestar que inflige inexoravelmente a todos. Mas, diferentemente de Lacan, essas novas 
abordagens baseiam-se na proposta de que os modos de resposta forjados pelos homens perante seu encontro com o Outro no laço social sofrem modalizações de acordo com os discursos dominantes de uma dada época, permitindo pensarmos o sintoma social em uma certa pluralidade, o que não necessariamente recai na ideia de uma "patologia das comunidades culturais" (Freud, "Mal-estar na civilização"), mas aponta para o fato de que "cada época organiza seus gozos e tem as patologias que merece" (CALLIGARIS, 1992, na apresentação do livro Alcoolismo, delinquencia, toxicomania, p. 10).

Contardo Calligaris reitera a importância, para a psicanálise, de manter-se à altura de escutar em cada sujeito o social. Do ponto de vista desse grupo de autores que se propuseram a pensar o social, mesmo aquele psicanalista circunscrito às paredes de um consultório não deve se eximir de sua responsabilidade no social. É preciso lembrar que essa era a posição do próprio Freud, que, em vários momentos de sua obra, se dirige à Cultura não apenas com uma ambição de compreensão, mas sim como resposta de um posicionamento ético diante do próprio sujeito.

Passamos agora a apresentar a abordagem proposta pelo psicanalista Charles Melman, que se tece na discussão sobre as toxicomanias, baseada na qual ele irá cunhar uma definição de sintoma social. Apesar de as toxicomanias não serem objeto de estudo desta pesquisa, iremos recuperar aqui o percurso das argumentações propostas por Melman ao definir o conceito de sintoma social e afirmar que as toxicomanias são um sintoma social.

"Não basta que um grande número de indivíduos em uma comunidade seja atingido por algo para que isso se transforme em sintoma social (...). Mas pode-se falar de sintoma social a partir do momento em que a toxicomania é de certo modo inscrita, mesmo que seja nas entrelinhas, de forma não explícita, não articulada como tal, no discurso que é o discurso dominante de uma sociedade em uma dada época" (MELMAN, 1992, p. 66)

E nossa época é marcada pelo o que Lacan descreveu como "ascensão ao zênite social do objeto a" (LACAN, 1970, apud LAURENT, 2007, p. 163), ou seja, a chegada do objeto a a seu mais elevado grau, a partir de uma trajetória de alguns séculos, que culmina no aparecimento do discurso de um mestre contemporâneo, que é o discurso do capitalista, que, como vimos no capítulo anterior, pleiteia subverter a falta, negar a incompletude e a incerteza inerentes à condição (linguageira) humana, e que, por este motivo, conduz a uma crise dos homens em relação à civilização e suas exigências de enquadre. 
Na década de 1960, menos de duas décadas após o término da Segunda Guerra Mundial, Adorno escreve o antológico artigo "Educação após Auschwitz", no qual defende a posição de que a primeira tarefa da educação é de que Auschwitz não se repita. No entanto, a intolerância entre os homens é efeito de seu gregarismo, e as leis que regulam suas relações mostram-se tão frágeis quanto precárias nos momentos em que o mal-estar não pode ser contido.

Foi apenas alguns anos antes que Hannah Arendt escreveu o seu (também antológico) ensaio "A crise na educação" (1958) - discutido no capítulo 1-, no qual articulou a crise na educação à da tradição e da autoridade: o adulto de mal com seu passado não se responsabiliza, perante a criança, por tudo que aí está, lava as suas mãos e exime-se de uma responsabilidade que deveria ser sua.

O discurso da ciência moderna, que vem se enraizando no campo político desde Descartes, oferece-se como aliado da ambição capitalista de apaziguar a dor da existência, ao oferecer fomento a seu intento de forjar um objeto capaz de aplacar o apetite e a voracidade do sujeito do consumo. Ciência e capital trabalham juntos na direção de negar a não totalidade da experiência humana e terminam por banalizar ou patologizar todo conflito. Em uma sociedade para a qual as motivações inconscientes devem permanecer veladas, não há tristeza que não vire fricote ou depressão.

Ao sujeito contemporâneo não é mais concedido o direito de duvidar, hesitar ou sofrer. Para que tudo isso? - é a pergunta que a sociedade nos devolve. Para que sofrer? Tome um remédio. O conflito psíquico, movido por inquietações inconscientes ou existenciais, vem sendo banido em prol dos distúrbios organicistas, para os quais nossa sociedade tem se empenhado em fabricar soluções.

No entanto, por mais esforço e por mais totalitária que seja a ação desse discurso, ela não chega de fato a totalizar: há um resto dessta operação que retorna como sintoma um sintoma social inscrito nos discursos dominantes de nosso tempo, que sobredeterminam os sujeitos, e que os afetam tanto no que diz respeito aos laços que estes estabelecem com seus semelhantes, como ao laço estabelecido com o grande Outro. O sintoma social se faz escutar através dos sujeitos, que podem fabricar diferentes respostas diante desse encontro: ele se situa entre o universal do mal-estar e o singular do sintoma subjetivo (VORCARO, 2004). 
Com base na leitura dos sintomas sociais, é possível esboçar um mapa da contemporaneidade: "cada época organiza seus gozos e tem as patologias que merece" (...) "cabe à psicanálise escutar como o social fala em cada um: o trabalho clínico deve desembocar em uma crítica do social" (CALLIGARIS, 1992).

$\mathrm{Na}$ interpretação de Charles Melman, a toxicomania é a resposta do sujeito contemporâneo ao mal-estar de nosso tempo. Esse mal-estar decorre da impostura de um convite feito à desmesura e ao excesso, e que produz no toxicômano um esmagador desejo de apagamento e de abolição de toda a vida.

O objeto do toxicômano é marcado pela ausência de qualquer referência ao gozo fálico. Ele recusa todos os valores fálicos, pois estes são fontes inequívocas de inconvenientes no que se refere a seu acesso ao objeto: o falo alude à falta, da qual ele nada-quersaber, e delimita necessariamente fronteiras, que lhe são extremamente inconvenientes. Evitando o gozo fálico, ele se libera das limitações que, de outro modo, lhe seriam impostas de modo imperativo. É por isso, diz Melman, que as toxicomanias são menos toleradas na sociedade do que o alcoolismo: o modo de gozar do toxicômano é estranho, pois diz respeito ao que Melman chamou de "gozo Outro".

Ao afirmar que a toxicomania é um fenômeno mais social do que individual, Melman quer dizer: "que sua propagação não depende somente da inclinação, do gosto ou da 'fraqueza psíquica' de um sujeito, mas também das incitações que podem ser exercidas pelo meio" (MELMAN, 1992, p. 101).

A toxicomania seria testemunha de uma "mutação cultural". Toda cultura dita regras para o gozo, enquadres que delimitam um campo possível para o gozo no social. Falar em uma transformação cultural implica apontar para uma transformação na economia do gozo. O sintoma social é algo que excede esse campo de legalidade, que é conferido pela cultura, para o gozo. Isso se dá, no entanto, sem que ele deixe de estar inscrito nos discursos dominantes ou hegemônicos, que traduzem o modo de estabelecimento do laço social em cada época e cultura. Sendo assim, o sintoma social está inscrito nos discursos, mesmo que seja em suas entrelinhas.

"Em nossa cultura judaico-cristã, a relação do sujeito com o objeto suscetível de satisfazê-lo não é jamais uma relação dual" (MELMAN, 1992, p. 102), mas sim uma relação sempre intermediada por uma instância terceira, que é reguladora e que pode comparecer em roupagens diversas: seja com o nome de Deus, da moral ou da razão. 
Os gregos já demonstravam, a seu modo, preocupação com a satisfação. Propunham pensá-la como algo que demandava temperança: a satisfação devia estar condicionada a uma certa prudência. Para os gregos, o desfrute requeria uma sabedoria que lhe fosse própria (phronesis).

Na toxicomania, no entanto, o gozo em questão alude à desmesura, à destemperança, à falta de referência fálica, numa relação de oposição à phronesis grega. O toxicômano goza de sua própria morte, buscando a abolição da existência, como se esta fosse a única alternativa social diante do mal-estar contemporâneo, que é marcado pela máxima capitalista de nada deixar a desejar.

O gozo do toxicômano é um exemplo paradigmático do modo de gozar do sujeito contemporâneo: submetido aos discursos da ciência e do capitalista, o homem de hoje se esforça na direção de negar os limites e os inconvenientes provenientes do gozo fálico, apegando-se à ilusão de que o objeto capaz de apaziguar sua dor de existir esteja ao seu alcance, na medida em que ele tenha condições (capital) para adquiri-lo.

Pode-se dizer, portanto, que os sintomas sociais veiculam modalidades de gozo $e$ ilusões que se ordenam dentro de uma lógica que é sobredeterminada pelos discursos dominantes de cada época.

Há algo que se repete na toxicomania tal qual uma estereotipia, marcada por um ideal veiculado pelo discurso do capitalista de encontrar um objeto capaz de apaziguar a um só tempo as necessidades e o desejo. Portanto, para Melman, o toxicômano realiza o sonho de todo neurótico.

Vê-se, então, de que modo a toxicomania pode se referir não apenas ao modo de organização libidinal de um sujeito, mas também a um modo de funcionamento social. Ela se constituiu como um sintoma social por metaforizar uma verdade da civilização (VORCARO, 2004).

$\mathrm{Na}$ esteira da elaboração proposta por Melman sobre a categoria de sintoma social, o psicanalista Alfredo Jerusalinsky irá afirmar que este propõe novas modalizações de gozo, isto é, novos ordenamentos lógicos dos modos de desfrutar a vida e de gerar e sustentar a ilusão de um saber (JERUSALINSKY, 1998).

O sintoma é sempre uma tentativa de simbolizar o real, um artifício construído pelo sujeito para manejar o impossível. E o modo particular de cada um responder a isso é sobredeterminado por um contexto que é coletivo, social. Sendo assim, os sintomas 
individuais se alimentam do imaginário social, com base no qual fazem a sua invenção (ibidem).

Todo sintoma consiste na construção de uma nova borda para o real, este incomensurável e irredutível campo de ignorância. E a modernidade vem se esforçando na direção da produção de uma borda discursiva capaz de recobrir completamente esse campo. Embasado por discursos que versam sobre supostas verdades sobre os homens, o projeto da modernidade é o de forjar um objeto capaz de recobrir completamente esse buraco constitutivo e fundamental para a vida subjetiva. A droga é representativa desse objeto.

Nesse contexto, caracterizado por uma ambição racionalista e positivista, constroem-se projetos de estandardização da vida, que definem critérios de normalidade e de eficiência.

No âmbito da instituição escolar, tal ambição incide de modo a fazer supor, em todo aquele que escapa ao ideal suposto de aprendizagem, uma patologia: o patológico é definido em referência a um sujeito construído, suposto como normal (ibidem).

Assim como o toxicômano realiza o sonho de todo neurótico de apaziguar sua dor de existir, defendemos a tese de que o não aprender da criança realiza o sonho neurótico de subversão dos limites, de negação da castração. E é esse o ponto que iremos desdobrar no próximo capítulo.

Antes de concluirmos, no entanto, e marcando uma posição nessa discussão, retomamos uma pergunta lançada pelo psicanalista Marcio Peter de Souza Leite (2008) em um ensaio sobre a psicanálise e o social: se não há cura para o mal-estar, por que nos dedicarmos a interpretar a cultura? Talvez porque, ao nos dirigirmos a uma leitura da Cultura, não estejamos exatamente embuídos do intuito de compreendê-la, mas sim de perseguir algo que se enuncia na fala de um sujeito em análise, e que demanda alguma medida de resposta. Pensar a Cultura, em nosso entendimento, é ser consequente a uma escuta do sujeito, e a um posicionamento ético que deve caber a todo aquele que aceita ocupar este lugar.

Pensamos ser possível desenvolver tais articulações em uma outra interrogação, que indaga o psicanalista sobre o seu posicionamento ético perante a Cultura, e essa posição nada tem a ver com pleitear ou sustentar nenhuma visão de mundo, mas sim com um reconhecimento de que a política do gozo própria à economia psíquica singular de um 
sujeito está indelevelmente articulada às modalidades de gozo forjadas por uma Cultura e sua época. Não responder em nenhuma medida a isso é, portanto, ignorar o corpo que se lança no rio, fingindo que não tem nada a ver com isso, como o fez o protagonista do livro A queda, de Albert Camus. Um psicanalista não pode se eximir da responsabilidade por aquilo que escuta. 


\section{III - Dos problemas na escola aos impasses escolares como um sintoma social}

A instauração da escolaridade obrigatória no Brasil, na década de 1990, imputou ao ensino formal inúmeras mudanças, que tiveram o objetivo manifesto de transformar um contexto caracterizado, desde seus primórdios, pela exclusão e pela evasão de alunos pobres, portadores de necessidades especiais ou simplesmente com dificuldades de aprendizagem. Com ela vieram as política da inclusão e da progressão continuada, com a missão de fazer frente à seletividade e à discriminação na escola.

Contudo, se, de um lado, a universalização do ensino é condição de um estado democrático de direito, de outro, sua implementação atrapalhada e atropelada (por questões econômicas e políticas que se sobrepuseram às questões educativas) acabou produzindo um acirramento da intolerância, perante as diferenças, e do próprio fracasso escolar.

Apesar de entendermos que o estudo da conjuntura do ensino e da escola no Brasil seja capaz de fazer aguçar uma compreensão a respeito do contexto político educativo nacional, o presente trabalho foca as questões estruturais que participam dessa cena.

O que viemos realizando ao longo desta dissertação é justamente o estudo do impacto das pungentes mudanças que se produziram no discurso social acerca da escola e da educação desde o cogito cartesiano. As mudanças nas políticas públicas, no que tange à educação, estão atravessadas por um discurso social que pleiteia $100 \%$ de sucesso, às custas de expulsar de seus domínios (não mais de seus muros, agora com a inclusão) e de sua responsabilidade tudo aquilo que resiste e que escapa a esse furor. Tal discurso tem tido o estranho destino de não mais legitimar e acatar o problema no interior da escola, fazendo com que vicissitudes do processo escolar, que invariavelmente coincidem com o lugar da dúvida, da hesitação e da não compreensão, se tornem impasses, cronificando alunos no lugar da não aprendizagem.

\section{Dos problemas aos impasses}

Problemas nas aprendizagens estão longe de ser uma novidade de nossos tempos. Bastou que um homem se debruçasse sobre um objeto com intenção de desvendá-lo para que os problemas começassem. Isso porque o objeto não se revela aos olhos dos 
homens tal qual uma imagem fotográfica em laboratório que, mágica e rapidamente, se insinua no papel em branco até o ocupar completamente, estampando-o e revelando-se a nós. Aliás, mesmo a fotografia já revelada traduz apenas um olhar, um instante flagrado, um detalhe, um recorte do tempo e do espaço. O que fazemos são ensaios e aproximações desse objeto, recobrindo-o com um campo discursivo.

As aprendizagens são modos não lineares de aproximações sempre parciais de um objeto. Sempre permanecerá um resto, um viés obscuro, que, vale lembrar, nunca é o mesmo de um sujeito para outro. Os modos de aproximação e apreensão do objeto diferem de pessoa para pessoa, bem como difere o campo do desconhecido em relação a esse mesmo objeto. E é por isso que os problemas nas situações de aprendizado são inevitáveis, posto serem vicissitudes desse processo. A novidade de nosso tempo não são os problemas na escola, mas estes terem se tornado impasses.

Um problema sempre comporta algum tipo de solução: ao menos é isso que fica sugerido após uma incursão pelas definições encontradas no dicionário (HOUAISS, 2002) no verbete problema. Vejamos: "situação controversa ou de difícil solução, que gera incômodo e que exige grande esforço e determinação para encontrar solução".

Entende-se daí que um problema porta um conflito e para ele não existem respostas prévias, existindo, no entanto, soluções. Um problema é algo perturbador, que preocupa e que se insinua como um desafio ao raciocínio e à capacidade de análise. Ele inquirenos, mobiliza-nos e convoca-nos para um debate.

Na educação matemática, por exemplo, um problema representa, ao mesmo tempo, um desafio e um estímulo à curiosidade do aluno. Nos processos que envolvem a resolução de um problema, o aluno utiliza seu conhecimento prévio, bem como lança mão de novas estratégias, ampliando a gama de noções matemáticas e aprimorando sua capacidade de raciocínio (PEREIRA, 2001). Entende-se que, para todo problema matemático, haja uma solução, que pode ser conhecida ou não. E este se torna tanto mais valioso quanto mais desafiador ele for, exigindo, da parte de seu "solucionador", a invenção de estratégias e a criação de novas ideias.

É bastante propícia a diferença que se estabelece entre "problema matemático" e "exercício matemático", muitas vezes equivocadamente utilizados como se fossem sinônimos dentro do campo desta disciplina. 
Um "exercício" é considerado uma atividade de treino de uma habilidade ou noção matemática, que já são conhecidas pelo resolvedor (ibidem, p. 4). Já o "problema" matemático se constitui quando, diante de um objetivo a ser alcançado, não sabemos como atingi-lo. Um problema, no campo da matemática, será considerado tanto melhor, do ponto de vista do ensino, quanto mais desafiador ele for, e quanto mais for capaz de "mexer" com a matemática ou, dito de outra forma, quanto mais "ele contribui para o desenvolvimento dos vários ramos da matemática" (ibidem, p. 5).

Antônio Luiz Pereira (2001) cita o problema de Fermat ${ }^{26}$ como um exemplo paradigmático de um bom problema matemático: apesar de conter um enunciado bastante simples (para um matemático!!), sua demonstração levou cerca de 400 anos para se efetivar, e "as tentativas de resolvê-lo produziram ideias e problemas que fertilizaram inúmeros campos da matemática, tais como a teoria dos números e a geometria algébrica" (ibidem, p. 5).

Um problema, portanto, é um desafio cuja solução atravessa processos que comportam, potencialmente, a capacidade de fertilizar o campo estudado, produzindo avanços e transformações.

É exatamente essa noção de problema que não deve jamais deixar de ocupar um lugar no terreno do aprendizado. Como se vê, um bom problema não apenas gera aprendizado como também mobiliza o desejo, ao instigar, perturbar ou desafiar.

No entanto, no campo pedagógico, um problema não vem sendo tomado como uma benfazeja vicissitude de todo e qualquer processo de aprendizado. Ele tem sido prontamente tomado como um transtorno, um déficit ou um desvio à norma.

Esse fato em parte ocorre porque, tão logo um problema venha a se impor, ele deve ser solucionado. Não se dá o tempo necessário para que uma ideia ganhe consistência, nem para que estratégias sejam requeridas ou inventadas. Espera-se que um problema possa ter uma solução certa e imediata.

As vicissitudes próprias ao aprendizado têm sido consideradas problemas não solucionáveis, ao menos dentro dos muros da escola; esta (falta de) disposição diante dos problemas escolares tem motivado um número grande de encaminhamentos.

\footnotetext{
${ }^{26}$ Problema de Fermat: sendo $n=3,4,5, \ldots$, mostrar que não há nenhuma trinca de inteiros positivos $\mathrm{x}$, $\mathrm{y}, \mathrm{z}$, verificando a equação $x^{n}+y^{n}=z^{n}$, ou seja, considerando que $n$ seja uma potência maior ou igual a 3 , e que $x, y$ e $z$ sejam números inteiros e positivos; esta equação jamais se verifica.
} 
A forte intolerância que se gesta perante essas ocorrências se deve ao fato de que, por maior esforço que se faça na direção de se recobrir o real pelo simbólico, o real continuará sempre infinitamente maior do que o campo dos significantes. E, agregado a esse resto não simbolizável, decorre um inevitável mal-estar, para o qual não há solução, mas há sim manejo.

As situações que divergem do esperado vêm sendo cada vez menos toleradas pelo discurso pedagógico, que se agarra com ímpeto e força a explicações forjadas às pressas (e superficialmente) sobre o problema em questão. Apesar de seu caráter pouco formal e pouco embasado, esse discurso ganha força na medida em que busca no discurso da ciência o seu respaldo.

É dessa forma que os problemas de percurso de um aprendizado se transformam, nos tempos atuais, em impasses. No dicionário Houaiss (2002), encontramos as seguintes acepções para a palavra impasse:

1 situação aparentemente sem solução favorável;

2 dificuldade insolúvel; beco sem saída;

3 qualquer fato ou coisa que dificulta ou impede; embaraço, empecilho.

Sem dúvida, as aprendizagens se veem em grande embaraço. Respondem diretamente a uma crise na educação que se evidencia pela fragilidade das instituições que deveriam se responsabilizar pelas crianças: a família e a escola. É justamente a ideia de beco sem saída que parece melhor se ajustar às enormes dificuldades enfrentadas hoje, em todos as instâncias - desde o poder público, passando pela família, até o professor em sala de aula -, para se educar uma criança.

É interessante observar que, apesar de a preocupação com a educação estar em voga, ocupando um espaço considerável no discurso social acerca da infância, o aprendizado e a escolarização das crianças permanecem obstaculizados e ameaçados.

Observamos o quanto o deslizamento significante do problema para o impasse vem produzindo mais embaraços do que ensejos no campo educativo, e como a busca frenética por uma resposta para aquilo que escapa ao enquadramento escolar tem feito proliferarem traduções que, o mais das vezes, utilizam como baliza para seus argumentos o léxico científico. 


\section{Olhares sobre os impasses}

Uma breve incursão pelo universo dos problemas escolares nos conduz rapidamente a uma constatação: muito se fala a respeito dos infindáveis obstáculos que assolam a escola hoje, no entanto, parece não haver consenso quanto ao modo de nomeá-los ou de entendê-los. Problemas, dificuldades, queixas, transtornos, distúrbios, déficits e fracasso são alguns exemplos de designações das questões que atravessam a instituição escolar. A cada um desses significantes foram se amarrando sentidos diversos.

Tentativas de explicação do fenômeno do fracasso escolar, cada uma dessas leituras são portadoras de influências teóricas e ideológicas diversas, que implicam intervenções também diversas. De que se trata? Problemas dos alunos ou improficiência dos professores? Problemas nas aprendizagens ou na socialização? Inconsistência na formação dos professores ou inépcia do poder público? Como intervir? Tratar a criança, capacitar professores ou analisar a instituição? Buscar soluções dentro da própria escola ou encaminhar? Encaminhar para quem? Para o professor particular, para o psicólogo ou para o psicopedagogo? Para o psiquiatra ou para o neurologista? Quem afinal detém a chave para o enigma que embaraça uma criança em suas aprendizagens?

A ilusão (psico)pedagógica ${ }^{27}$ que pleiteia um convívio harmônico e natural entre ensinantes e aprendizes crê, com todas as suas forças, que alguém detenha a resposta às questões acima formuladas.

Afirmamos aqui, porém, que essa resposta não existe. Não há remédio para o irremediável! Não há solução para o furo que a linguagem produz. Não há como evitar as fraturas, os lapsos e os erros. Não temos a nosso alcance nenhum maquinário capaz de conter e controlar o encontro de um aluno com seu professor e com o conhecimento ali transmitido.

Não queremos dizer com isso que não existam caminhos, que estratégias não possam ser inventadas, nem que não haja possibilidades de mudança e de dissolução para os conflitos que aí estão. Pretendemos ressaltar o caráter pernicioso dos vieses que se seguem a essa ambição de controle. Ganha-se em realidade e perde-se em sonho (MUSIL, 1989). Quem sai perdendo nessa história é o sujeito, cuja marca singular e

\footnotetext{
27 Sustentada pela tese de uma suposta adequabilidade entre a intervenção do adulto e a resposta da criança, como se houvesse uma equiparação entre as dimensões psicológica e pedagógica.
} 
humanizadora é o desejo, e cuja vocação é a dúvida, não a certeza. A leitura aqui defendida sugere que entre todas essas questões ocorre uma articulação. Entendemos que esses problemas imiscuem-se no cenário escolar em uma espécie de injunção.

Questionar por que uma criança não aprende não é suficiente para respondermos à inquietante pergunta sobre o alto índice de alunos com problemas de aprendizagem nas escolas. É preciso também examinarmos o alto índice de professores acometidos por transtornos psíquicos, como a depressão, o pânico, a úlcera e outras somatizações. Outra indagação imprescindível se dirige aos pais: por que eles vacilam em assumir seu lugar de autoridade perante seus filhos, e quais as consequências dessa recusa para a educação?

As dificuldades escolares não se resumem às dificuldades isoladas dos sujeitos, mas respondem a uma complexa trama tecida no campo social e político, produzindo grandes embaraços no campo escolástico como um todo.

As dificuldades e os desafios da educação hoje não são apenas objeto de interesse e discussão dos profissionais dessa área, mas assunto corrente no extramuros escolar. Desde o cidadão comum, passando pelo médico ou pelo economista, escutamos uma repetida preocupação concernente à educação e seus percalços.

Se, por um lado, podemos reconhecer nessa inquietação um traço em comum entre esses diversos personagens ou entre essas diferentes disciplinas, que se repete no discurso social acerca da educação, inclusive sinalizando, por conta disso (como apontamos no capítulo II), a inscrição desse sintoma no social, por outro lado, ao aproximarmo-nos dessas discussões, iremos encontrar uma diversidade de olhares que respondem a influências teóricas e ideológicas específicas. Dessas diferentes influências decorrem intervenções também muito diversas.

Elegemos três dessas interpretações das dificuldades escolares para aprofundarmos a discussão. Essa escolha foi motivada pelo fato de se tratarem de três abordagens influentes tanto pelo seu impacto na cena escolar como pela sua presença no discurso que se tece sobre a educação fora do campo específico da escola. Além disso, o exame mais pormenorizado de cada uma delas permitirá definir mais claramente as diferenças entre essas intervenções e a intervenção que é realizada pelo Trapézio, instituição que será analisada no último capítulo. 
As abordagens que serão foco deste estudo, ou melhor, as influências sobre as quais iremos nos debruçar a seguir são: o trabalho da psicologia escolar, a concepção da psicopedagogia sobre os problemas escolares e sua proposta de intervenção, e o discurso médico e sua pregnância no discurso escolar hoje.

Antes disso, porém, faremos uma breve discussão a respeito da constituição da psicologia como ciência e do compromisso ideológico que ela firma ao aceitar o lugar social de promover a eficácia. Isso se faz necessário na medida em que as abordagens apresentadas a seguir ou se colocam de um modo crítico em relação à entrada da psicologia na vida escolar (como é o exemplo da psicologia escolar) ou, alijadas de uma reflexão mais crítica, deixam-se cooptar pelo furor normativo, que, ansiando pela adaptação e pelo aprimoramento a qualquer custo, conduzem justamente a seu reverso, acirrando a patologização do cotidiano escolar.

Georges Canguilhem (2012) conclui seu artigo sobre o que é a psicologia colocando-a diante da decisão de qual caminho tomar estando ela, à saída da Sorbonne, entre o Pantheón, lugar de alguns grandes homens, e a chefatura de polícia. Suas origens apontam para a segunda opção, resta a ela definir a qual destino ela visa.

Influenciada desde seus primeiros passos no terreno da ciência por um mosaico de ideias que misturam - como apontou esse mesmo autor: "uma filosofia sem rigor, uma ética sem exigência e uma medicina sem controle" (CANGUILHEM, 2012, p. 402) -, a psicologia forja (força) um campo conceitual próprio, renegando suas influências no campo da filosofia e abraçando as causas do aprimoramento, da adaptação e da eficiência.

Até o nascimento da psicologia científica, a psicologia era um ramo da filosofia, que se dedicava ao estudo da alma. Chama a atenção de Canguilhem que a psicologia, que etimologicamente significa ciência da alma, tenha negligenciado a influência de uma tradição aristolélica que considerava a alma um ser natural.

A esse respeito, afirma Canguilhem: "O tratado aristotélico Da alma é (...) um tratado de biologia geral, um dos escritos consagrados à física (...). O objeto da física é o corpo natural e organizado" (ibidem, p. 404).

Apesar disso, é possível reconhecer a influência desta tradição de pensamento sobre os campos da psicopatologia e da psiconeurologia. Para fazer da psicologia uma ciência, os primeiros psicólogos do século XIX entenderam que deviam aperfeiçoar seu 
instrumental metodológico e, para isso, tomaram como modelo as ciências naturais. Essa ambição e filiação conceitual imprimiram à psicologia a marca de uma prática que mais se interessou pelos seus instrumentos do que por um corpo teórico consistente e coerente. Com isso, erigiu sua práxis sobre tratados reducionistas e mal fundamentados, sobre um solo de indefinição teórica para o qual, dentre outras coisas, há uma (pseudo)equivalência entre alma e consciência. Agregou-se a isso um furor pela mensuração e pelo controle, o que corroborou a psicologia a eleger como seu objeto o comportamento observável e controlável (a aptidão, a cognição e a personalidade).

Não é para menos que o marco do nascimento da psicologia científica tenha sido a fundação do laboratório de psicologia, por Wilhelm Wundt, em Leipzig, em 1879, cuja ambição foi fazer da psicologia uma ciência experimental do comportamento e dos fatos da consciência.

A concepção de comportamento que está na base dessas novas abordagens da psicologia é um "conjunto de reações adaptativas, objetivamente observáveis, que um organismo executa respondendo a estímulos, também observáveis, procedentes do meio em que vive" (DELEULE, 1972, apud PATTO, 1984, p. 92). Nota-se, nessa definição, uma influência da biologia, de onde foram tomados emprestados os conceitos de organismo, estímulo e adaptação, bem como uma influência das ciências exatas, das quais se extraiu instrumentais de observação e quantificação.

Logo os primeiros testes de personalidade e de medição da inteligência são criados e não tardou para que o aparato psicométrico fosse convidado a entrar nas instituições escolares, com o objetivo de identificar os alunos mais capazes e oferecer instrumentos que otimizassem suas aprendizagens. O compromisso da psicologia educacional era o aumento da eficiência da escola como um todo, mostrando que portava a mesma matriz ideológica adaptacionista da psicologia científica.

Em seu trabalho "Psicologia e Ideologia: uma introdução crítica à psicologia escolar" (1984), Maria Helena Souza Patto afirma que a ideologia é um sistema de pensamento pautado pela ilusão, cuja lógica se caracteriza pela dissimulação e pela ocultação. Seu discurso discorre sobre as aparências. É por isso que a ideologia dificulta que se estabeleça uma relação cognoscível com o objeto.

A ciência, por sua vez, deveria ser capaz de levar luz ali onde o discurso ideológico produziu um obscurecimento. É certo que toda ciência possui suas determinações 
ideológicas. No entanto, uma revolução científica só se fará com base em uma ruptura ideológica, capaz de inaugurar um novo recorte epistemológico, que conduza à impugnação da concepção hegemônica de mundo.

A psicologia não teria, com suas novas teses, levado a nenhuma ruptura epistemológica (ibidem). Sua aparente novidade estaria no empréstimo de conceitos tomados de outros campos, utilizados com uma nova roupagem, para retificar e não para transformar.

Das três abordagens apresentadas a seguir, a psicologia escolar é aquela que pleiteia subverter essa lógica normativa, com vistas a promover uma transformação social. A psicopedagogia é herdeira do pacto ideológico firmado pela psicologia no começo do século XX. Embora encontremos dentro desse campo psicopedagogos de inspiração psicanalítica, que tentam encontrar saídas para esta questão, veremos que o discurso oficial da psicopedagogia está amarrado ao ideário cientificista, conduzindo a práticas reabilitativas que pouco refletem sobre sua função social. Por fim, discorreremos sobre o modo como o discurso médico entra hoje na escola, promovendo um rapto de todo e qualquer traço distintivo do sujeito. Nas leituras psicologizantes e organicistas dos problemas escolares, podemos recuperar o lastro desse compromisso ideológico, que obscurece o objeto e ignora as questões políticas estabelecidas no interior da instituição escolar.

\subsection{Da psicologia escolar}

Nas primeiras décadas do século XX, os problemas de aprendizagem e de rendimento escolar já eram alvo da atenção de alguns grupos de psicólogos. Nesse período, distinguiam-se basicamente duas linhas de atuação nesse campo: a psicologia escolar e as clínicas de orientação infantil.

A nascente psicologia educacional propunha-se a oferecer à pedagogia um embasamento científico para sua atuação, cabendo-lhe a tarefa de lançar bases para a compreensão da dimensão psicológica do processo educacional, e de oferecer instrumentos de medida, previsão e controle dos processos de aprendizagem.

Nas clínicas de orientação infantil preponderavam procedimentos diagnósticos baseados em testes projetivos e de inteligência, seguidos de atendimentos psicoterapêuticos individualizados. Tais diagnósticos apontavam para problemas nos alunos, que podiam 
ser de origem psicológica, fonoaudiológica, neurológica ou psiquiátrica, que dificultavam ou impediam sua aprendizagem. O contexto escolar, em suas dimensões política e econômica, não era levado em consideração (PATTO, 1984).

Com o objetivo de fazer um contraponto à vigente psicologia educacional e de imprimir novas possibilidades para a atuação do psicólogo na escola, a psicologia escolar começa a ganhar espaço na década de 1970, estando fundamentada em uma análise crítica da escola e de suas relações com a sociedade.

Tendo por base as teorias críticas de Althusser ${ }^{28}$ e Bourdieu, que trouxeram "à luz o papel ideológico, domesticador e excludente da escola" (PATTO, 2004, p. 9), a psicologia escolar nascente dedica-se a escancarar as amarras ideológicas da psicologia em sua atuação dentro da escola, que mais se prestava à manutenção de situações de injustiça social flagrantes do que a um real cuidado com aquilo e aqueles que não iam bem. Influenciada pelas críticas reprodutivistas ${ }^{29}$, passa a conceber as dificuldades de aprendizagem de crianças de classes populares de um modo radicalmente diverso, fazendo com que o foco de sua atuação deixasse definitivamente de ser o aluno para ser a instituição (ibidem, 2004).

Fazer frente ao fracasso escolar, na concepção da psicologia escolar, implica realizar intervenções exclusivamente no âmbito institucional, esperando-se que a desestabilização das certezas ideológicas, que caracterizam as relações no cotidiano escolar, possam conduzir a um reposicionamento dos sujeitos aí envolvidos. Critica-se tanto as leituras psicologizantes como as organicistas, por desconsideram as relações (de poder, submissão e humilhação) que se estabelecem no interior da instituição escolar, levando professores a desqualificar alunos e alunos a se calarem.

O fracasso escolar, explicita Patto, não diz respeito ao fracasso do aluno, mas ao colapso de um sistema educativo, que está mais compromissado com a manutenção do status quo do que com a educação de nossas crianças. Isso redunda em relações perversas no cotidiano escolástico, que produzem alunos com problemas.

\footnotetext{
${ }^{28}$ A entrada do materialismo histórico no campo de estudos sobre a educação se deu pela concepção althusseriana da escola como aparelho ideológico do Estado. Para Althusser, a escola é o aparelho ideológico dominante do Estado e, como tal, cumpre o papel social de assegurar a reprodução das relações de produção próprias às sociedades classistas.

${ }^{29}$ As teorias crítico-reprodutivistas entendem não ser possível compreender a educação senão a partir de seus condicionantes sociais (SAVIANI, 2001).
} 
Em consequência desse posicionamento, a psicologia escolar entende como uma grande distorção tomar em tratamento o aluno com problemas, porque, assim sendo, este é colocado como foco do problema e a instituição escolar se isenta de sua responsabilidade.

Respondendo à teoria da curvatura da vara, a psicologia escolar produziu um tensionamento em direção ao social, como se este estivesse em posição oposta à do sujeito.

\subsection{Da psicopedagogia}

São muitas as "caras" da psicopedagogia, tornando difícil a definição de seu campo. Dentro dele encontramos influências diversas, desde uma psicopedagogia organicista a uma psicopedagogia de inspiração psicanalítica. Há trabalhos psicopedagógicos que se definem como uma ajuda ao aluno; outros, como um trabalho cuja ética é a da transformação social. Sua origem está associada ao aumento de crianças com distúrbios de aprendizagem (RUBINSTEIN, 1987).

No geral, seu objeto é o aprendiz e a palavra-chave de sua atuação é a interdisciplinaridade (ibidem). Segundo Edith Rubinstein, seu propósito é "compreender o indivíduo enquanto aprendiz" (ibidem, p. 15) com basicamente duas formas de atuação, a clínica, "mais voltada para a terapêutica (recuperação)" (ibidem), e a institucional, voltada à prevenção: "acreditamos ser possível evitar problemas" (ibidem).

Janine Mery, psicopedagoga francesa, considera o psicopedagogo "um professor de um tipo particular [que] deve realizar sua tarefa de pedagogo sem perder de vista os propósitos terapêuticos de sua ação” (MERY, 1985 apud BARONE, 1987, grifo nosso). Nessa perspectiva, ao psicopedagogo cabe a transmissão do conhecimento, sem que se perca de vista os fatores psicológicos que interferem no ato de aprender.

Para Beatriz Scoz, a origem da psicopedagogia no Brasil coincide com um momento crítico de falência do ensino no país, tendo como objetivo melhorar a qualidade da escola pública e possibilitar a todas as crianças o acesso ao conhecimento (SCOZ, 1994). Ainda de acordo com esta autora, a psicopedagogia deve se inserir em um movimento mais amplo de luta pela transformação da sociedade. Com relação aos 
problemas de aprendizagem, irá afirmar que estes "não são restringíveis nem a causas físicas ou psicológicas, nem à análise de conjunturas sociais [...] é preciso compreendêlos a partir de um enfoque multidimensional, que amalgame fatores orgânicos, cognitivos, afetivos, sociais e pedagógicos" (ibidem, p. 22, grifo nosso).

Vê-se que, mesmo entre profissionais filiados a uma mesma associação ${ }^{30}$, o objeto e os objetivos desse campo não estão claramente definidos. Ora parece-nos estar claro tratarse do sujeito epistêmico, logo somos surpreendidos com afirmações que definem como objeto desse campo o sujeito desiderativo, e, em outras circunstâncias, parece que o objeto é a sociedade!

Bastante significativa é a presença do verbo "amalgamar" no texto de Scoz, referindo-se ao aspecto multidimensional (sic) dos problemas de aprendizagem. Infere-se de sua afirmação que a psicopedagogia aspiraria ter um novo objeto do conhecimento costurado por fragmentos arrancados de outros corpus teóricos.

Em seu livro De Piaget a Freud. Para repensar as aprendizagens. A (psico)pedagogia entre o conhecimento e o saber (1992), Leandro de Lajonquière esforça-se por demonstrar a não equivalência dos conceitos erigidos no campo da epistemologia genética e os oriundos da psicanálise.

Em decorrência disso, entendemos que o equívoco da psicopedagogia é epistemológico: sua práxis estima um objeto-amálgama, no qual se supõe uma indiferenciação entre inteligência, afeto e corpo biológico.

Lajonquière reconhece que tal construção epistêmica se assenta sobre a suposição de uma continuidade entre a ordem do real e a ordem do pensar, que, por sua vez, alimenta a ideia de que entre as disciplinas haja uma inter-relação. A interdisciplinaridade pressupõe justamente "uma operação de articulação teórica" (ibidem, p. 130), de "um tranquilo território de passagem (...) entre uma teoria e outra" (ibidem, p. 131).

O reconhecimento de uma indelével articulação entre pensamento e desejo, e de uma sobredeterminação do social sobre o sujeito, se assenta sobre a ideia de uma transdisciplinaridade (e não de uma interdisciplinaridade ${ }^{31}$ ), que se delineia com base no reconhecimento das idiossincrasias próprias a cada campo epistêmico e da recusa de

\footnotetext{
${ }^{30}$ Associação Estadual de Psicopedagogos de São Paulo.

${ }^{31}$ Apontada no texto de Rubinstein (1987) como a "palavra-chave" da psicopedagogia.
} 
uma costura teórica entre campos teórico-práticos distintos, construídos sobre noções de sujeito absolutamente não proporcionais (LAJONQUIÉRE, 1992).

Fazer a crítica da psicopedagogia, no entanto, não equivale, de modo algum, a negligenciar a pertinência de intervenções que possam apoiar alunos que estejam enfrentando dificuldades em seu processo escolar, e corroborar com mudanças no cenário escolar.

Muitos esforços vêm sendo realizados para oferecer à prática psicopedagógica uma sustentação teórica capaz de responder às contradições com as quais um profissional dessa área se encontra em sua práxis, favorecendo uma conceitualização "sobre as vicissitudes que os sujeitos suportam em suas aprendizagens" (LAJONQUIÉRE, 1992, p. 130). Nesse sentido, o trabalho de Sara Pain foi fundamental. Ao incluir o sujeito do inconsciente e o desejo no bojo de suas reflexões acerca das fraturas no aprender, promoveu um refreamento do furor pedagógico de fazer a criança aprender a todo custo. A ignorância passou a ter uma função no interior da economia psíquica de um sujeito e, assim, o não aprender conquistou um novo estatuto.

Como bem lembra Leandro de Lajonquière, se a educação hoje se converte em um fato de difícil acontecimento, isso está diretamente relacionado ao império do que este autor chamou de ilusão (psico)pedagógica - aquela que pleiteia uma suposta adequação entre o agir do adulto e seus efeitos sobre a criança. Ainda segundo Lajonquière, é essa ilusão que anima o discurso pedagógico hegemônico, cuja crença maior é a de que "saber é poder" (1992, p. 15).

Tal discurso se encontra arraigado nas práticas erigidas sobre as tais vicissitudes suportadas por um sujeito em suas aprendizagens, e encontramos sua pregnância desde a sala de aula até o interior dos consultórios (psico)pedagógicos. O seu desvelamento pode contribuir para que a psicopedagogia continue avançando em seu esforço por oferecer uma filiação epistêmica mais sólida para seu campo de atuação.

\subsection{Do discurso médico}

Se as (psico)pedagogias colaboraram para fazer inflar a ilusão de adequabilidade e controle das ações de um adulto em relação a uma criança e, com isso, fizeram crescer uma forte intolerância dirigida àqueles que fazem resistência a essa impostura (os 
alunos que não aprendem), o retorno de leituras organicistas sobre os impasses escolares pretende deter a resposta final e verdadeira sobre o que realmente se passa quando uma criança se embaraça em suas aprendizagens: a causa está no organismo. Sem se perguntar sobre as diferenças entre organismo e corpo, entre limite e causa, entre alma e coisa, o discurso médico faz uma entrada muito mais devastadora e perniciosa, do ponto de vista do sujeito, do que a psicologia jamais pôde pretender.

Vale lembrar que a conjugação medicina-pedagogia não é recente. Esta se inaugura com Itard, ao empreender sobre Victor, o menino selvagem ${ }^{32}$, o seu "tratamento médico moral" ${ }^{33}$, com vistas a promover aquilo que seu abondono teria lhe usurpado: sua educação. O equívoco de Itard foi acreditar que a inserção social e a aquisição da fala fossem atributos "naturais", manipuláveis pela técnica e pelo adestramento. Itard, assim como Schreber, apostaram suas fichas na plausabilidade de "tornar real um ideal de natureza suposta" (LAJONQUIÈRE, 2010, p. 147). Ambos inverteram o caminho próprio à educação, que parte do desejo de transformar o real infantil em um ideal de adulto (ibidem, p. 146). O tratamento moral (ou a pedagogia) de Itard se caracterizou por um furor pedagógico tal que seu destino não poderia ter sido outro senão a própria renúncia ao ato educativo: não há como educar sem desejo e sem a suposição de sujeito no outro.

O que o discurso médico provoca hoje no cenário escolar parte de tal origem, mas, em nosso entendimento, representa um agravamento da (in)disposição que encontramos nesses dispositivos para com as coisas do desejo, posto que sua medida de resposta àquilo que interpreta enquanto sintoma não produz outra coisa senão silêncio.

A medicalização desmedida e irresponsável atende à expectativa de silenciar os corpos, para usar os termos de Foucault. Seu compromisso não está vinculado a uma terapêutica, mas sim a uma contenção, o que conduz, em primeira e em última instância, à morte do sujeito.

\footnotetext{
${ }^{32}$ Garoto de aproximadamente 12 anos, encontrado em estado de completo abandono, no final do século XVIII., que foi submetido a um tratamento médico moral, conduzido pelo médico Jean Itard.

${ }^{33} \mathrm{O}$ tratamento moral assim era chamado porque incidia sobre as faculdades mentais, e não sobre o corpo, e este consistia em humanizar pela via da educação.
} 
"Em lugar das paixões, a calmaria, em lugar do desejo, a ausência de desejo, em lugar do sujeito, o nada..." (ROUDINESCO, 2000, p. 41). É assim que a psicanalista Elizabeth Roudinesco resume o efeito do discurso médico em nossa sociedade depressiva, que tem se esmerado por transformar a alma em uma coisa.

Importa observar que tal discurso apenas logra seu intento, posto encontrar no sujeito contemporâneo um "novo homem, polido e sem humor, esgotado pela evitação de suas paixões, envergonhado por não ser o ideal que lhe é proposto" (ibidem, p. 21) e sedento por se fazer instrumento da máquina social.

O resultado disso na cena escolar é o fenômeno da medicalização. Prescrições medicamentosas para as fraturas do sujeito. O olhar médico vislumbra, ali onde o sujeito vacila, resiste ou erra, a evidência de uma causa orgânica que deve ser "atacada", "eliminada".

Para a psicanálise, no entanto, o sintoma é uma resposta construída laboriosamente pelo sujeito diante de seu encontro com o Outro. Não se trata de "atacá-lo", mas sim de escutá-lo, não se trata de eliminá-lo, mas buscar uma dissolução.

\section{Dos impasses escolares como um sintoma social}

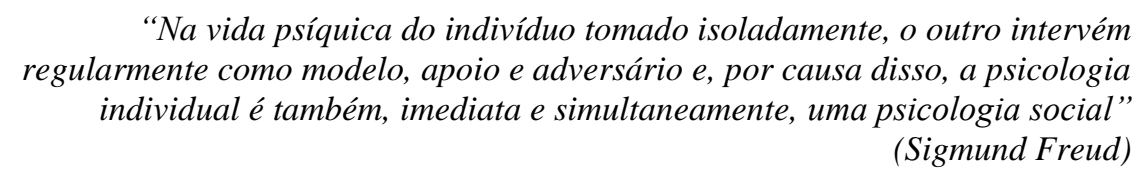

A noção de sintoma social é signatária de um movimento no interior da psicanálise que - para além da atenção que esta pode despender ao sofrimento psíquico individual de cada sujeito - fez recuperar o papel desta como teoria da cultura e sua função no social. O sintoma social metaforiza uma verdade da civilização. E sua interpretação, apesar de não ter o efeito de cura, pode ter o fundamental ganho de abalar os alicerces de suas certezas, produzindo mudanças discursivas que são capazes de impactar a vida subjetiva das pessoas.

Ao afirmar que os impasses escolares são um sintoma social, entende-se que os sintomas subjetivos, que se constroem na escola, são respostas laboriosas e singulares forjadas pelos sujeitos (sejam eles a criança, seu professor ou um de seus pais) perante 
seu encontro com um discurso social acerca da educação que pleiteia o sucesso e rejeita o fracasso.

Entendemos que, baseado no sintoma subjetivo, podemos escutar o sintoma social, e que a interpretação do sintoma social permite elucidar os modos de organização do gozo em uma dada época.

Partimos do entendimento de que o social e o subjetivo estão imbricados. O sociólogo francês Bernard Charlot, estudioso da psicanálise e pensador da educação, afirmou que somos $100 \%$ seres do social, bem como $100 \%$ seres do singular. Mas isso não implica sermos 200\%. O que ele explicita com essa brincadeira é que, do ponto de vista da psicanálise, o social não é pano de fundo: o sujeito se constitui nesse encontro, e nele se entranha.

Lembrando o que já discutimos no segundo capítulo, não há uma psicanálise do individual e outra "aplicada" ao sintoma social, pois o sintoma é sempre social; ele é sempre efeito de uma rede discursiva que excede o campo do sujeito.

As ilusões que sustentam a prática educativa e aquilo que a escola endereça às crianças enquanto demanda são elementos que se modalizam de acordo com seu tempo. As subjetividades e as instituições buscam suas figuras necessárias na abertura vazia de suas possibilidades (FOUCAULT, 1988).

De um modo bastante genérico, podemos dizer que a escola é a síntese de uma resposta dos homens, infinitamente complexa, lastreada e lapidada ao longo da história das civilizações, às questões da identidade, da memória, da tradição e da transmissão, que se modalizam de acordo com a época e seus costumes. Entendemos que o lugar social que uma escola ocupa em uma certa sociedade corresponde a um ponto para o qual convergem sobredeterminações políticas, sociais e econômicas, além da sobredeterminação do desejo. Uma escola é fruto do encontro da intenção de sistematizar a transmissão de conhecimento com o desejo de educar.

Entretanto, é importante também observar que, entre o que ela se propõe a transmitir e o que de fato ela transmite, entre o que ela deseja e o que de fato ela faz, ocorre um hiato. Um hiato inevitável, diga-se de passagem, posto tratar-se de uma engrenagem discursiva que escapa o tempo todo das tentativas de significações precisas, tornando impossível um ajuste perfeito entre uma determinada ação e seu resultado subsequente. Como a escola e os educadores (não custa lembrar que por educador entendemos 
qualquer adulto na relação com uma criança) lidam com esse hiato, com a sua falta, faz toda diferença.

No primeiro capítulo, vimos que a escola considera esse hiato insuportável, movendo-a a buscar uma costura possível. Imersa em uma sociedade que funciona sob a égide do discurso do capitalista, a escola está tão submetida quanto qualquer outra instituição ao imperativo de nada deixar a desejar, do gozar a todo custo. No entanto, especialmente para a educação, a tentativa de supressão do lugar de enunciação do sujeito, de sua verdade, a torna, nas palavras de Lajonquière, um fato de difícil acontecimento.

Podemos pensar essa situação do ponto de vista do professor, dos pais, bem como da criança. Comecemos pelo adulto. O adulto é aquele que chegou ao mundo antes, e dele se espera uma responsabilização pela iniciação da criança no mundo (ARENDT, 1957). Mas ele somente será capaz de sustentar essa posição em relação à criança na medida em que se autorize a falar em nome próprio. A queixa o frequente de que os bebês não chegam ao mundo portando um manual de instrução revela de maneira flagrante o desamparo do adulto diante da exigência que se lhe impõe quando se vê perante uma criança.

$\mathrm{Na}$ ausência de um manual redentor, que supostamente portaria as respostas para os enigmas impostos pelo encontro de um adulto com uma criança, nossa sociedade criou para ele representantes. O professor faz uso das teorias (psico)pedagógicas em voga e os pais fazem uso do saber médico ou psi, tal qual um usuário utiliza um manual: espera-se que o saber ali contido possa ser transmitido passo a passo, de modo claro e objetivo (de preferência com ilustrações!), para que não reste nenhuma dúvida de que o produto final sairá a contento.

Caso algo dê errado no meio do caminho, não restará nenhuma dúvida de que o problema estava no manual. Observamos que, sem autoria, não há transmissão possível e que, por mais contraditório que possa parecer, não há nada mais antinômico em relação à educação do que o desejo de tudo saber. Afora isso, a transmissão do conhecimento não se dará de forma mecânica e os saberes não devem ser confundidos com utilitários ${ }^{34}$.

Por outro lado, a supressão do lugar da enunciação desde a perspectiva da criança a conduz ao lugar (discursivo) de objeto. A criança identificada com o lugar de quem

\footnotetext{
${ }^{34}$ Lembro-me de um artista plástico que usava palitos para confeccionar obras minúsculas. Sobre elas, ele dizia: "minhas obras são inutensílios".
} 
nada sabe só pode responder com seu não aprender. Na verdade, como bem nos revelou Maud Mannoni a respeito da dinâmica das instituições, as cartas estão postas de tal modo na mesa que qualquer aceno da criança reiterará aquilo que se quer ler nela.

O que está em jogo nessa cena, tão trivial nos dias de hoje, diz respeito à hegemonia, no campo educativo, de um discurso que fala em nome de um saber que não é seu, fazendo do outro um objeto. Trata-se do discurso do universitário. Lacan irá aproximar este do discurso da burocracia, no qual nunca se fala em nome próprio e o outro nada mais é do que uma cifra, um item ou uma estatística. Não há sujeito de um lado nem do outro: no lugar do agente, o saber ${ }^{35}$, o sujeito sapiente, e no lugar do outro, o objeto $a$. O que esse discurso produz é o sujeito alienado ou a exclusão do sujeito (FINK, 1998).

Este é também o discurso que Lacan irá aproximar do discurso cientificista, caracterizado por uma ambição totalizante e uma intolerância à verdade do sujeito. Esta Essa verdade, entendida como o lugar de enunciação do sujeito, é banida ou banalizada do discurso social comum, revelando o horror desse discurso por tudo que não é objetivável. A ambição de eliminar o inexplicável e de fundar um sujeito sem afeto está no cerne do impossível circundado por esse discurso, que está no âmago da afirmação de que os impasses escolares são um sintoma social.

No discurso social sobre a educação, a ambição cientificista se revela imperiosa. De um lado, não devemos produzir sobre os discursos valorações, já que não há entre eles o melhor ou o pior, tratando-se somente de formalizações sobre o encontro do sujeito com o Outro, que podem produzir facilitações ou embaraços. De outro lado, a hegemonia de um discurso denota o avanço de uma ambição totalitária. A esse imperativo podemos qualificar como uma impostura, e essa a tendência totalitária devemos, desde a posição de analistas, fazer frente.

\subsection{Da ideologia do rendimento ${ }^{36}$ : o fracasso é o reverso do sucesso}

O discurso social sobre a educação hoje insiste em situar o aluno no lugar do fracasso. O "fracasso" é um rótulo que pretende fazer caber dentro de si as inúmeras e diferentes situações de não aprendizado. Nunca é demais lembrar, no entanto, que a realidade

\footnotetext{
${ }^{35} \mathrm{O}$ saber do discurso universitário corresponde a uma "mera racionalização", "um tipo de esforço enciclopédico para esgotar um campo" (FINK, 1998, p. 163).

${ }^{36}$ Subtítulo do capítulo "Os paradoxos da teoria como saber", do livro Educação Impossível (1988), de Maud Mannoni .
} 
(psíquica) do sujeito não é jamais coletivizável. O não aprender tem infinitas caras! É preciso uma aproximação minuciosa dessa resposta que o sujeito forja em seu encontro com a demanda escolar para que se possa supor aí um sentido.

Não há como, contudo, negligenciarmos a escolha do termo "fracasso" e sua pregnância no discurso social sobre os problemas escolares, estando imersos em uma sociedade cujos valores mais prezados são o capital, o consumo e o sucesso. O sucesso escolar ocupa um lugar de imperativo em nossa sociedade e está associado a uma suposta conquista de status social e de poder de consumo. Aposta-se que uma educação ideal (e exitosa) seja exequível e, para tanto, basta que se invista corretamente e de modo seguro.

A educação atual se edifica sobre um castelo de ilusões, signatárias do eu ideal freudiano, que representa a completude imaginária, assentando-se sobre o lugar da certeza. Essas ilusões se postam em oposição aos ideais: "o ideal representa o sujeito enquanto sujeito da falta (...) e representa o provável” (FREIRE COSTA, 1991, p. 121). O ideal "aponta para o futuro em vez de deixar-se amarrar pelo passado" (ibidem., p. 120). A função do ideal para o aparelho psíquico é convidar o sujeito a avançar em direção ao mundo, flexibilizando-se em relação às exigências de autoconservação infligidas pelo $\mathrm{Eu}$.

Já no âmbito do eu ideal, "a exclamação precede o ato e o dota de sua qualidade" (BLEICHMAR, 1985, p. 62). O eu ideal porta uma incondicionalidade que o torna não combatível. Nessa esfera, não é o admirável que produz a admiração, mas sim a admiração antecipada e incondicional, crente na perfectibilidade do eu ideal, que produz o admirável.

Para o psicanalista Jurandir Freire Costa, nosso tempo se caracteriza por um imperativo narcísico que não gera outra coisa senão violência. Tempos sombrios ${ }^{37}$ de exaltação narcísica, que conduz a um declínio dos ideais que, por sua vez, produz um empuxo ao gozo.

\subsection{Não há problema que uma falta de solução não possa resolver ${ }^{38}$}

\footnotetext{
${ }^{37}$ Fazemos aqui referência ao título do artigo de Jurandir Freire Costa "Narcisismo em tempos sombrios" (1991), que, por sua vez, alude ao livro When it was dark, de C. Rangel (1903), citado por Freud em "Psicologia das massas e análise do eu" (1921), uma ficção que elocubra sobre as vicissitudes da dissolução de um grupo religioso.

${ }^{38}$ ANAXIMANDRO apud MILLER, 2006.
} 
Em um debate realizado em 2003, entre o linguista Jean-Claude Milner e o psicanalista francês Jacques Alain-Miller sobre o tema da avaliação, colocou-se em pauta a voracidade do poder administrativo por abocanhar a fatia indócil do real, através de seu ciframento.

Na abertura de sua fala, Milner expõe a preocupação que o motivou a colocar a questão da avaliação na pauta da discussão psicanalítica: o fato de o Estado ter se imputado o direito e o dever de tornar matematizável o malviver. Na medida em que o Estado passa a entender o malviver como assunto de saúde pública, ele busca esquadrinhá-lo, tanto com o objetivo de entendê-lo (à exaustão) como para definir a melhor forma de atacá-lo. A questão que se coloca é: como se organizarão as profissões que se ocupam do malviver?

A resposta que Milner e Miller construirão nesse debate é o desnudamento da máscara burocrática da avaliação que, por vezes se apresenta como uma sereia sedutora, segundo Miller, que se insinua tanto pela mendicância de seu apelo como pela impostura de sua promessa.

Miller atenta para o fato de que o avaliador se apresenta desde o lugar de quem nada tem e endereça ao futuro credenciado o seu pedido de sereia e a sua promessa: dê a mim o seu saber, compartilhe comigo de sua riqueza, consinta nesta partilha, e, assim, seremos como deuses.

A partilha, elucida Miller, é a máscara do roubo: "pois um tem algo para partilhar, que é o saber de sua prática, enquanto que o outro não tem nada, nenhum saber efetivo", a não ser "o poder de credenciar ou não, de reconhecer ou não, o puro poder do carimbo" (ibidem., p. 26).

E a promessa, sobre o que ela se sustenta? Sobre o desejo mais arcaico dos homens de ser um entre os outros, de deixar de ser único, de se deixar imiscuir até que se evanesça qualquer resíduo daquilo que lhe causa (e que lhe cobra) o desejo de não ser responsável por suas escolhas, de não se implicar e deixar-se conduzir. Exatamente nesse ponto se constituiu sua impostura: a avaliação pede ao outro que partilhe o traço próprio a seu desejo, para torná-lo uma cifra, e, assim, destituí-lo de qualquer singularidade, de qualquer humanidade. 
Com roupagens científicas, a avaliação faz parte de um projeto de ciframento do ser, que se inaugura com a divisão entre saber e verdade, filha lógica do cogito cartesiano ${ }^{39}$ (ibidem).

Milner traduz o aparato administrativo de controle com base em dois paradigmas do mundo moderno: o paradigma do problema-solução e o da avaliação. Nesses termos, tudo é passível de ser cifrado; para todo problema sempre há uma solução.

E a avaliação é um instrumento de controle cuja essência maior reside na anuência por parte do avaliado. Nas palavras de Miller, "A avaliação é a busca metódica, incansável e extremamente maligna do consentimento do outro" (MILLER, 2006, p. 24).

Nos documentos oficiais, aquele a quem se avalia é oficialmente o demandeur, aquele que demanda, como se tivesse sido o avaliado que tivesse originalmente solicitado o seu próprio submetimento ao processo avaliativo.

A avaliação pressupõe um contrato, que supõe, por sua vez, que haja equivalência entre as partes tanto em termos do poder que cabe a cada uma delas como àquilo que ambas teriam para trocar entre si.

O efeito do contrato se distingue do efeito da lei: "a lei permite tudo o que ela não interdita expressamente" e "funciona tanto pelo que diz quanto por seu silêncio" (MILNER, 2006, p.7), referendada sempre por um terceiro. Já o contrato elimina a triangulação, convida para uma relação “equiparada” entre duas partes. Um contrato ${ }^{40}$,

\footnotetext{
${ }^{39}$ Vide capítulo 1.

${ }^{40}$ Para entender um pouco mais sobre o impacto do contrato sobre o laço social moderno, vale recuperar o momento de sua entrada no cenário político. A base societária moderna é hobbesiana, contratualista, o que significa dizer que funciona sobre a base jurídica. Thomas Hobbes é considerado o pai da filosofia política moderna. Para ele, a condição humana é a de predisposição para a guerra, uma guerra movida pelas paixões humanas e por uma crença em uma igualdade natural entre os homens. Essa igualdade dotaria os homens de capacidades iguais, o que alimentaria seu desejo de poder obter o mesmo que os outros para si. Não podendo obter este objeto, o homem se torna o inimigo. Não é à toa que Hobbes é associado à máxima homo lupus hominis, o homem é o lobo do homem. Pelo reconhecimento de uma tendência dos homens a responderem desde o lugar de suas paixões, e não como cidadão, Hobbes irá postular a necessidade de um instrumento para legislar as relações humanas: o contrato. Ele reconhecia nas ações humanas uma labilidade, por estas estarem balizadas por desejos e vontades. Pergunta-se, então, como, diante dessa condição, as pessoas podem viver coletivamente, como podem sustentar um corpo social e político, se tendem a colocar seus próprios anseios à frente dos anseios da sociedade. Dada essa instabilidade das relações entre os homens, sugere ser preciso um instrumento de ordenação do coletivo, que não ficasse tão exposto a esse padrão, um instrumento não sujeito à labilidade humana, caso contrário, o desacordo correria o risco de chegar a um ápice de violência, levando os homens a se matarem. Este instrumento seria o contrato, uma forma de limitar ou minorar o impacto das vontades de cada um sobre o coletivo. O contrato tenta restringir o impacto da labilidade humana sobre o que foi previamente contratado, aceito e combinado entre as partes. No entanto, Hobbes reconhecerá que o contrato em si mesmo não é capaz de se autorregular. Uma vez algo tendo sido contratado entre duas partes, o que irá assegurar que isso será efetivamente realizado, que o contrato será respeitado? Hobbes reconhece aí a necessidade de uma instância hierarquicamente superior às partes contratantes, para
} 
afirmará Miller, se constitui no esforço de conferir estatuto simbólico ao estádio do espelho. No contrato, o silêncio não opera, apenas atua aquilo que foi detalhadamente expresso.

A avaliação, bem como a junção problema-solução e o contrato, tornaram-se paradigmas do mundo globalizado. Esses paradigmas expressam o projeto político do ciframento.

Do impacto disso tudo sobre o campo educativo, já discorremos ao longo dos primeiros capítulos. Iremos nos dedicar a seguir à análise de um dispositivo institucional de atendimento dirigido a crianças e jovens que apresentam impasses em seu percurso escolar.

garantir que o contrato seja cumprido. Esta instância seria "Leviatã”, que representa o Estado. É preciso, finalmente, um instrumento capaz de garantir que as pessoas tomarão como referência o contrato para se balizarem em suas interações sociais, coletivas e políticas. O Estado é a instância obrigatória para garantir que o contrato seja cumprido. Mas como o Estado faz isso? Por intermédio da espada pública, da violência, que seria de posse exclusiva do Estado. Não haveria outra maneira mais eficaz na manutenção dos contratos do que a violência. É por isso que a violência, o instrumento da espada pública na manutenção do contrato, precisará ela também ser coibida, controlada, pelo Estado (ENDO, 2009 e LIMONGI, 2002). 


\section{IV - Análise de uma experiência institucional}

\section{Instituição e psicanálise}

“É preciso produzir uma instituição tal que permita a existência, no interior dela mesma, de tantas instituições quantos forem os sujeitos que as habitam."

(Alexandre Stevens)

Instituição pode denotar tanto uma organização que realiza ações de interesse social ou coletivo, como também estruturas e costumes sociais que vigoram em uma determinada comunidade, tenham sido elas estabelecidas por lei ou de modo consuetudinário (HOUAISS, 2002). "Uma instituição é alguma coisa que se mantém de pé in statuere" (LAURENT, 2007, p. 237); mais que isso, é um tipo de estrutura que se mantém em compromisso com a manutenção daquilo que foi estabelecido. Uma instituição é uma máquina que não quer se tornar obsoleta. Por outro lado, instituir também pode estar designando o ato ou o efeito de dar começo a alguma coisa, de criar ou instaurar algo (HOUAISS, 2002).

Há, então, um aspecto da instituição que a destina à repetição, há outro, porém, que a faz trombar com situações novas, que ela tenderá a interpretar como estranhas. Essa situação paradoxal é o que pode fazer do trabalho institucional algo extremamente vigoroso ou algo potencialmente mortífero.

$\mathrm{O}$ aspecto conservador da instituição prevalece e a mantém obrigada a uma lógica discursiva que se apresenta praticamente como antinômica em relação à abertura que o sujeito do desejo demanda para não sucumbir à alienação. O compromisso que as instituições selam no momento de sua fundação é o de não deixar ruir, o compromisso de manter sua estrutura em funcionamento. O governar tem nas instituições seu habitat natural e o discurso que melhor traduz esse modus operandi é o discurso do mestre, no qual o mestre escraviza em nome da manutenção de seu status, ordenando e dirigindo.

Para cumprir sua vocação de fixar, as instituições precisam colocar de lado (no caso, abaixo da barra ${ }^{41}$ ), no lugar do que está esquecido e recalcado, o sujeito e sua verdade. É preciso lembrar que o esquecimento é condição de todo e qualquer pensamento. Todo

\footnotetext{
${ }^{41}$ A estrutura do discurso postulada por Lacan possui quatro lugares e quatro elementos que circulam em uma certa direção, e que são separados por duas barras (como uma barra de fração). O que está abaixo da barra é o que está recalcado no discurso em questão.
} 
discurso precisa esquecer algo para poder se organizar, e, no caso do discurso do mestre, é esquecido tudo aquilo que diz respeito ao singular.

As instituições não podem considerar o singular e tendem a rejeitar as novidades. Vivem, entretanto, um conflito entre esse apelo (e esse apego) desmesurado pelo conhecido e o inevitável encontro com o novo, afinal, todo recalcado retorna. Por mais totalitário que seja o mestre, ele jamais logrará totalizar completamente. A hegemonia almejada pelo mestre não atingirá a todos de forma homogênea. A impostura que lhe é caracterítica, a saber, não considerar o singular e o desejo de impor-se a qualquer custo, é sempre não toda feita, instigando a criação de sua própria oposição.

Uma instituição precisa cuidar para que esse zelo pelo conhecido, pelo já instituído, não se torne uma obsessão. Em uma instituição, a psicanálise deve desestabilizar a ideia imaginária de um todo e permitir aberturas para as surpresas e para as invenções. Não deve entrar na instituição como teoria mestra, mas sim como baliza ética, permeável à ideia de que a instituição será sempre não toda e de que não detemos um saber prévio sobre o percurso de quem quer que seja. A psicanálise tem a função de garantir o particular e de flexibilizar o discurso do mestre, que tende à univocidade e ao totalitarismo.

O sujeito barrado é a fórmula lacaniana para os limites do sujeito, sua castração e seu desejo. O sujeito não pode tudo porque está submetido às leis da linguagem, o que faz com que sempre esteja presente um lugar vazio e suas operações, invariavelmente, produzam um resto.

No entanto, é próprio aos sujeitos, e às instituições por eles forjadas, almejar a superação dessa condição faltosa. Há, no interior do próprio pulsar do desejo, uma ambição pela totalização, pela suturação da falta, pela negação de qualquer lapso.

Para que uma instituição não atue em seu funcionamento esse desejo, que é mortífero do ponto de vista do sujeito, é preciso, em primeiro lugar, reconhecer tal tendência. Em seguida, criar mecanismos e manejos que permitam frear essa voracidade, resguardando espaços para a irrupção do singular e do novo. 


\subsection{Bonneuil: uma instituição barrada (e uma fonte de inspiração...)}

Bonneuil $^{42}$ é um exemplo de instituição que se preocupou em estabelecer, no interior de seu funcionamento, a destituição enquanto valor. Maud Mannonni nomeou essa estrutura como uma instituição eclatée: "estourada" em algumas traduções, "estilhaçada", em outras. A proposta embuída nessa ideia é desestabilizar a mestria e o empenho do mestre no exercício da dominação para garantir uma estabilidade.

"A estrutura de toda e qualquer instituição tem por função a conservação de um bem adquirido, para fins de reprodução da herança recebida" (MANNONI, 1988, p. 75).

Mas a reprodução da herança recebida é sempre não toda feita. É importante levar em consideração o fato de a mestria ser conservadora em relação à preservação de seu patrimônio, mas não no que tange a sua prática. Dizendo de outro modo, a repetição é inevitável, mas deixa brechas. Ela é própria ao circuito pulsional, que persegue o reencontro com um instante perfeito. Mas esse instante, ou o objeto perdido, foi para sempre perdido: ele jamais será reencontrado, mas apenas contornado. A repetição é apenas uma força sem conteúdo. Apesar de todo seu esforço, não logra repetir a experiência passada tal e qual: algo de novo, à revelia do desejo do mestre, inevitavelmente irrompe ${ }^{43}$.

Rearranjos acontecem, mas os que o mestre engendra não conduzem eles mesmos à irrupção de nenhuma grande novidade. Para recuperar de fato o valor do encontro e garantir a irrupção do singular e do novo, é preciso renunciar à ordem, sem abdicar da lei.

Bonneuil pretende tornar superlativa a situação do encontro, do laço social e, assim, fazer frente à tendência das instituições de se defenderem "contra os efeitos de toda palavra livre" (ibidem, p. 75). Foi como "um lugar para viver" que Mannoni melhor definiu Bonneuil: um lugar que garanta o particular por uma articulação entre lei e desejo, afinal, não há laço social sem interdição de gozo.

\footnotetext{
${ }^{42}$ A Escola Experimental de Bonneuil foi fundada, na França, em 1969, por Maud Mannoni, com o objetivo de oferecer um lugar de pertinência e tratamento a crianças excluídas do sistema regular de ensino.

43 "Repetir repetir - até ficar diferente.

Repetir é um dom do estilo".

(BARROS, 2004)
} 
Influenciada pelo movimento da antipsiquiatria e pelas ideias de Basaglia a respeito da instituição de tratamento de saúde mental, Mannoni pretendeu fazer de Bonneuil uma espécie de antiinstituição capaz de fazer abalar as resistências diante das inovações. No entanto, "não basta colocar o prefixo anti para se ficar livre dos efeitos esclerosantes da instituição" (ibidem, p. 76); "é necessário igualmente agir de maneira que as crianças não se fixem nos papéis estabelecidos" (ibidem, p. 79). Para tanto, Bonneuil se monta de modo a permitir sua própria desmontagem. Tudo se passa em função da supravalorização de tudo que é insólito e do engendramento de brechas que permitem a irrupção do novo, como explicita Mannoni na citação a seguir:

\begin{abstract}
A noção de instituição eclatée, que foi por nós introduzida, tem em vista aproveitar e tirar partido de tudo que de insólito surja (esse insólito que temse o costume de reprimir). Portanto, em vez de oferecer permanência, a estrutura da instituição oferece, sobre uma base de permanência, aberturas para o exterior, brechas de todos os gêneros. O que sobra: um lugar de recolhimento, um retiro (ibidem, p. 79).
\end{abstract}

Toda a (des)montagem institucional de Bonneuil está desenhada com base em um entendimento da criança psicótica como aquela para quem falta a falta e, por consequência, o desejo.

A alternância de um ateliê para outro, e de um profissional e seu estilo para outro, marcam presença e ausência, permanência e descontinuidade. Nessa circulação descontinuada, almeja-se que um sujeito emerja.

É fundamental, em Bonneuil, que a posição dos adultos não esteja marcada ou fixada pelo lugar do especialista. Cada adulto deve se dirigir às crianças enquanto sujeito, em primeira pessoa, e não em nome de um saber da ciência. Espera-se que esses adultos sejam capazes de lidar com o grande enigma que a criança psicótica porta, não buscando significá-lo a qualquer custo (como fazem as mães dos psicóticos), suportando a angústia inerente ao não saber e respondendo a seu modo, no imprevisto dos acontecimentos e no improviso de um manejo, à criança.

Outra característica de Bonneuil é o encontro do trabalho clínico com o educativo. Com o objetivo de mergulhar as crianças na cultura dos homens, são ofertados espaços que propiciam a criação e a invenção - os ateliês. Nestes espaços, os adultos têm a sua relação com a criança intermediada pela arte, pela história, pela letra. É fundamental, no trabalho com essas crianças, que o adulto possa criar um jogo simbólico no qual sua demanda não seja diretamente dirigida à criança, já que o Outro com o qual a criança 
psicótica se relaciona não é barrado em sua desmesura e em sua voracidade, e tudo o que ela faz é desviar-se o tempo todo desse encontro letal. É preciso recuperar o valor simbólico perdido neste excesso de real.

A cultura dos homens, explicita Kupfer (2000a), "não se cansa de falar às gerações seguintes sobre o modo como as anteriores se houveram com a castração, com o desejo insatisfeito, com o temor da morte, com a perigosa desmesura do gozo. Em uma palavra, falam de seu modo de abordar o real" (ibidem, p. 100).

Vê-se como o educativo comparece nesta instituição de tratamento como protagonista e não como coadjuvante. Aposta-se na direção subjetivante do encontro com os grandes portadores de significantes e com a lei que regula o laço social.

O trabalho de Bonneuil - assim como o de outras instituições que aceitaram o desafio de revisitar a teoria e a prática da clínica da psicose infantil - recuperou a discussão acerca do encontro entre psicanálise e educação, já consolidado e legitimado no terreno do tratamento das psicoses infantis, mas ainda pouco discutido no tratamento de crianças neuróticas.

\section{Do enfrentamento do educativo ${ }^{44}$}

Na conclusão de seu livro Freud antipedagogo, a psicanalista Catherine Millot relembra a afirmação do próprio Freud, em seu Estudos sobre a Histeria, de que "o único progresso que a experiência psicanalítica nos autoriza esperar é (...) a transformação de nossa miséria neurótica em uma infelicidade banal, e a de nossa impotência no reconhecimento do impossível" (Millot, 1992, p. 157). Tudo o que um pedagogo pode aprender com a psicanálise, ela nos dirá enfaticamente, diz respeito a "saber pôr limites a sua ação". O que, precisamos reconhecer, já é bastante coisa!

Passados mais de 30 anos da publicação original do livro de Millot, este se mantém como referência para todos aqueles que se arriscam nesse campo de trabalho. Com consistência e rigor em suas argumentações e conclusões, essa autora mapeia questões epistemológicas fundamentais próprias ao campo de encontro entre psicanálise e educação, colocando em destaque as impossibilidades de aplicação direta da psicanálise na práxis pedagógica e de integração entre esses dois campos.

\footnotetext{
${ }^{44}$ Citação ao título de um artigo de Maria Cristina Kupfer (2000b).
} 
A prática, no entanto, não comparece apenas como uma confirmação da teoria. Uma série de experiências, em especial de instituições de atendimento a crianças psicóticas e autistas, orientadas pela psicanálise, viram-se obrigadas a encontrar brechas para sua atuação, questionando e relativizando os contundentes alertas de Millot. Esse movimento permitiu que, gradativamente, fosse sendo conferido a essas práticas um novo status, bem como tornou mais precisas as críticas exaustivamente discutidas por essa autora, mas já antes anunciadas pelo próprio Lacan, quando este afirmou, no seminário II, que os procedimentos pedagógicos são absolutamente estranhos à experiência analítica (LACAN apud KUPFER, 2000b).

Não se trata de combater a antinomia entre sexualidade e civilização. Aprendemos com Freud, em "Mal-estar na civilização", que esta é uma condição estrutural da vida social: o mal-estar não é contingente. Em decorrência disso, boa parte da sabedoria dos homens se encontra na escolha de qual tratamento dar ao irremediável conflito que há entre as exigências pulsionais e as exigências de enquadre e de restrição pulsional impostas pela civilização. Daí decorrerão sua capacidade criativa, sua abertura para novas ideias e o seu limiar de (in)tolerância para enfrentar o encontro, sempre espinhoso ${ }^{45}$, com o outro.

Em outras palavras, a vida em sociedade é a fonte social do sofrimento, mas também é ela que nos permite a experiência da felicidade, mesmo que esta seja sempre tão fugaz. Para Freud, é papel da educação promover um arranjo, sem pretensões de aplacamentos ou suturações, entre vida pulsional e realidade social.

$\mathrm{Na}$ clínica com crianças, esse caráter da educação se fará presente. A prática psicanalítica com crianças requer um enfrentamento do educativo, tal como sugere Maria Cristina Kupfer (2000b). O educativo invade o setting do tratamento analítico de uma criança, seja pela via da escuta dos pais ou da escola, seja pelos inúmeros "nãos" que precisam ser proferidos dentro desse contexto.

Para dar conta desse desafio, no entanto, foi necessário precisar melhor os conceitos com os quais trabalhamos nesse campo e responder, munidos de um instrumental

\footnotetext{
${ }^{45}$ Sempre vale lembrar a bela imagem dos dois porcos-espinhos a qual Freud alude para descrever o amor e a dor de se encontrar com um outro: o porco-espinho precisa se aproximar de seu semelhante para se aconchegar, para se aquecer ou para procriar, mas é preciso descobrir, a cada encontro, qual o lugar e a posição de cada um, para que essa busca pelo outro não seja apenas dolorosa ou mortífera. (FREUD, 1930)
} 
teórico revisado, às argumentações contrárias à aproximação entre psicanálise e educação.

O primeiro passo se deu pelo reconhecimento de que, até então, educação e pedagogia foram abordadas de um modo indistinto, o que exigiu um esforço na direção de elaborar uma leitura mais específica da educação, distinguindo-a radicalmente da pedagogia enquanto uma práxis.

É preciso reconhecer a especial contribuição de Maud Mannoni nesse debate. Muito embora ela tenha também defendido uma dicotomia radical entre os campos da psicanálise e da educação, na prática, ao instituir "Bonneuil", Mannonni prova que a psicanálise tem muito mais a oferecer à educação do que simplesmente uma clareagem. Leandro de Lajonquière (2000) extrai consequências importantes a respeito dessa conexão com base na experiência de Bonneuil. O autor afirma que a pedagogia, diferentemente da educação, se define enquanto um saber positivo sobre uma suposta adequação natural entre meios e fins, o que a torna antinômica em relação à psicanálise. Entretanto, ele explica, pedagogia e educação não se equivalem; uma educação atravessada pela psicanálise é uma educação não pedagógica, que reconhece o desejo.

A educação se ocupa da transmissão de saber e conhecimento; ela é responsável pela transmissão de marcas simbólicas que produzem filiação. Já a pedagogia é uma práxis que se dedica à reflexão e à sistematização dos processos de ensino e de aprendizagem. A pedagogia conta com a manutenção do recalque e uma suspensão do desejo, enquanto a educação se ocupa de tornar possível o laço social e, para isso, é preciso dar lugar ao desejo, sem, evidentemente, deixar de considerar o mundo.

Concordamos com Lajonquière quando este afirma que todo adulto ocupa para uma criança o lugar de educador. Até mesmo um analista em seu consultório não poderá se eximir das inúmeras situações nas quais é convocado a portar a voz da lei. É preciso ir além, não há como apagar a diferença geracional que há entre um adulto e uma criança: viemos antes, somos os "velhos" (LAJONQUIÈRE, 2010a). E, do lado da criança, é preciso lembrar que está em jogo não apenas uma imaturidade do ponto de vista de seu desenvolvimento, que demandará um desdobramento em uma temporalidade cronológica, como também e, fundamentalmente, o fato de que o sujeito está em constituição, processo que se desdobrará em uma temporalidade lógica (KUPFER, 2000b). 
O que se delineia nesse processo de estruturação subjetiva é a elaboração de uma cartografia, que tornará disponível para o sujeito mapas e coordenadas, conferindo-lhe um lugar e a possibilidade de se situar no laço, em relação a seu desejo e ao outro.

Uma educação atravessada pela psicanálise, como já dissemos, reconhece o desejo, sem deixar de considerar o mundo. Ela participa, como vimos, do processo de constituição subjetiva no qual irão se articular desejo e lei, e as aprendizagens dependem dessa articulação. Uma criança psicótica, para quem a castração não operou, é capaz de decodificações ou de apresentar as chamadas "ilhas de inteligência" (aprendizados que não entram em uma cadeia e nem fazem laço social), mas ela não será capaz de apre(e)nder o objeto de conhecimento. $\mathrm{O}$ aprendizado requer uma ida até o campo do Outro para recolher o que ali lhe interessa. O aprendizado não se dá de modo passivo! Nem se dá fora do laço social. Ele sempre ocorrerá na relação com um outro (até mesmo o autodidata precisa estar referido a um outro para aprender).

\section{O trabalho de apoio à escolarização: da invenção de uma prática discursiva no social ${ }^{46}$}

O trabalho de apoio à escolarização concebido pelo Trapézio diz respeito a um conjunto de intervenções situadas entre o tratar e o educar, que visam a apoiar a escolarização de crianças e jovens que estejam enfrentando impasses em sua escolarização, a fim de que estes possam inventar uma nova possibilidade de se encontrar com suas aprendizagens e para que a escolarização deles, que esteve em risco, possa prosseguir apenas com seus percalços inevitáveis.

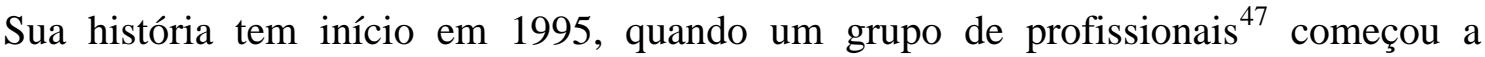
pesquisar o fracasso escolar, mobilizados pela pergunta "por que tantos alunos com problemas nas escolas hoje?”. Dessa pergunta inicial logo se desdobraram outras: "por que tantos professores enfrentando dificuldades no exercício de sua profissão?" e "por que tantas famílias tão embaraçadas ao educar seus filhos?”.

De um modo pouco formalizado, mas já presente, desde o início estava uma desconfiança de que, para se ler o cenário atual, no qual os problemas escolares se

\footnotetext{
${ }^{46}$ Citação à proposição do grupo "O sexto lobo" (vide página 47).

${ }^{47}$ Do grupo inicial faziam parte as psicanalistas Carolina Bacchi, Flavia Vasconcellos e Renata Dabori, e o educador João França. Em pouco tempo, outros profissionais se interessaram em participar desse grupo, que ainda era um grupo de estudos sobre o tema; são eles: Daniela Hanff (psicanalista), Isabel Moreira Ferreira (psicanalista) e Rita Paula Cardoso (fonoaudióloga).
} 
tornaram epidêmicos, não bastava uma leitura que colocasse todo o foco do problema na criança, tampouco na instituição escolar.

O Trapézio se fundou sobre outra premissa: a de que acontece um curto circuito no encontro entre a criança, sua família e a escola, marcado por uma imbricação de sobredeterminantes sociais e subjetivos que produzem desimplicação. O que marcou o momento de fundação dessa instituição foi a busca por uma ferramenta ou um dispositivo que respondesse a essa premissa, e que permitisse ler e intervir sobre esses problemas como algo que comparece na situação do encontro, na situação do laço.

Durante um ano, o primeiro grupo de profissionais (que viria a fundar o Trapézio) se reuniu semanalmente essencialmente para estudar, para conhecer o trabalho de outras instituições, suas leituras e intervenções. Ainda sem uma existência jurídica, e denominando-se "Grupo da Tarde" 48 , esses profissionais constituíram o germe do que viria a ser o Trapézio. Ao final de um ano de estudo, decidiram criar um dispositivo de intervenção sobre os impasses escolares e tiveram a oportunidade de experimentá-lo, em uma espécie de balão de ensaio, durante dois anos, atendendo crianças da rede SESI de ensino $^{49}$. As crianças que frequentam as escolas da rede SESI são, geralmente, pertencentes a uma camada da sociedade menos favorecida. A maior parte das vagas são oferecidas para filhos de industriários e uma outra pequena parte das vagas nessas escolas é destinada a famílias de baixa renda das comunidades próximas às escolas, que são sorteadas.

Com essa experiência, a equipe do Trapézio daquela época localizou no dispositivo um novo aspecto que não tinham se dado conta antes, que nomearam, de um modo genérico, como uma "vocação para o social". Tal aspecto dizia respeito ao alcance das intervenções, que podemos chamar de um alcance social, na medida em que a mudança de posição de um sujeito pode provocar uma mudança na rede discursiva a qual ele está submetido, produzindo mudanças em outros sujeitos que dela participam.

Foi essa compreensão que embasou a decisão, em setembro de 1999, de fazer desse grupo informal uma instituição com a existência jurídica de uma associação sem fins

\footnotetext{
${ }^{48}$ Porque o horário de reunião deste grupo era às quintas à tarde.

${ }^{49}$ Quase todos os membros da equipe do Trapézio nessa época eram também membros da equipe da Préescola Terapêutica Lugar de Vida, que firmou um convênio com o SESI para atendimento de crianças de sua rede de ensino que estivessem apresentando questões em seu processo escolar. O Lugar de Vida, generosamente, convidou nosso grupo para realizar esse trabalho.
} 
lucrativos, o que permitiria que fossem atendidas crianças das redes pública e privada de ensino.

\subsection{Das premissas que embasam o dispositivo de apoio à escolarização do Trapézio}

O dispositivo do Trapézio se apoia sobre o entendimento de que social e subjetivo estão imbricados e de que, com base no sintoma subjetivo, pode-se escutar o sintoma social ou, se preferirmos, de que a escuta do sintoma social permite um mapeamento das patologias de uma dada época.

A esse respeito, o sociólogo francês Bernard Charlot, estudioso da psicanálise e pensador da educação, diz: somos $100 \%$ seres do social, bem como $100 \%$ seres do singular. Mas isso não implica sermos 200\%. Do ponto de vista da psicanálise, o social não é pano de fundo, o sujeito se constitui nesse encontro, e nele se entranha.

Ainda sobre esse ponto, o psicanalista Contardo Calligaris afirmou que não existe uma psicanálise do individual e outra "aplicada" ao sintoma social, pois o sintoma é sempre social (CALLIGARIS, 1992, p. 12). O que chamamos de singularidade é sempre efeito de uma rede discursiva que excede o campo do sujeito, que é a rede do coletivo. Calligaris usa uma bela metáfora para ilustrar isso. No prefácio do livro Clínica do social (ibidem), relata que o grupo de psicanalistas, do qual ele fazia parte, que se pôs a pensar as articulações entre psicanálise e o social, decidiu se entitular "O sexto lobo" e ele explica por quê. Ao relatar seu sonho para Freud, o homem dos lobos menciona seis ou mais lobos apoiados sobre os galhos de uma árvore, mas seu desenho registra apenas cinco. Na interpretação de Calligaris, esses lobos representam aquilo que excede o quadro parental estrito da nossa árvore genealógica, que corresponde ao social. Somos fruto de uma ação sobredeterminada, na qual fatores de ordem social e fatores que dizem respeito a nossa economia de gozo se coadunam.

O pensamento mecanicista sobre os impasses escolares acaba produzindo uma relação entre culpado e vitimado. Mas não é suficiente apontar a pobreza como causa do fracasso escolar, tese defendida pelas teorias crítico-reprodutivistas, segundo as quais a educação reproduz as desigualdades sociais. É preciso atentar para o fato de que uma inclinação estatística não coincide com uma determinação causal. A pobreza pode se 
constituir como um indicador estatístico do fracasso escolar, na medida em que revela que essa camada da população possui uma fragilidade. No entanto, esta não deve ser entendida como causa, afinal, têm muitas crianças pobres que atravessam sua escolarização vivendo apenas seus inevitáveis percalços.

Não se trata de sair à busca de culpados e vitimados. Todo o trabalho do Trapézio se apoia sobre outra premissa: a da responsabilização. O sintoma que é objeto das intervenções nessa instituição é a desimplicação: os pais estão desimplicados, crentes de que o professor, o médico, o psicólogo ou a ciência sabem mais sobre seu filho do que eles próprios; o professor também se desimplica de sua responsabilidade de educar quando seu aluno "difícil" recebe um diagnóstico; com isso, seu aluno passa a ser problema de outro profissional que não ele, e ele deixa de refletir sobre quais estratégias poderia adotar com esse aluno em sala de aula; e o aluno também se desimplica, acaba se identificando com o lugar daquele que nada sabe, no qual é colocado, e deixa de se lançar no esforço e no risco inerentes a qualquer processo de aprendizagem.

Retomando o curso de ideias que foram desenvolvidas nos primeiros capítulos desta dissertação, a desimplicação como traço sintomático responde a uma sociedade para a qual a subjetividade, o particular ou o estranho são alvos de banalização ou horror. E o discurso que paira sobre o campo educativo hoje porta, por um lado, uma forte ambição de controle dos acontecimentos e, por outro, uma consequente intolerância em relação a tudo aquilo que escapa a esse aparato. Esses traços, somados à recusa de se responsabilizar, característica do adulto contemporâneo, conduzem a um cenário antieducativo!

Hannah Arendt afirma que o ato educativo deve promover tanto uma aderência da criança ao solo comum da tradição como uma abertura para que esses mesmos jovens possam transformar as tradições públicas. Em termos psicanalíticos, podemos dizer que o ato educativo, que visa a filiar o sujeito à Cultura pela transmissão de marcas simbólicas, tanto funda o sujeito quanto anima a civilização. É nesse sentido que entendemos que a educação não é apenas partícipe da vida pública, mas também protagonista no processo de constituição subjetiva.

O Trapézio recebe, em sua maioria, crianças neuróticas para tratamento. E, apesar do curso de sua constituição subjetiva já ter trilhado o tempo edípico ou sofrido os efeitos das operações de alienação e separação, conferindo a elas uma posição desejante, as 
crianças que chegam ao Trapézio estão de tal modo coaptadas ao lugar discursivo de objeto que parecem impedidas de pensar.

Sabemos o quanto uma escolarização malconduzida pode produzir exatamente o oposto do que uma educação deve propiciar para um sujeito. Assim como uma instituição psiquiátrica pode ser antiterapêutica, uma escola pode ser antieducativa, cristalizando o aluno em uma determinada posição em relação ao saber e ao conhecimento (VOLTOLINI, 2010).

Em casos extremos e graves, o encontro de uma criança embaraçada em suas aprendizagens, e com poucos recursos simbólicos, com uma escola pouco disponível para lidar com situações desafiadoras em sala de aula é capaz de produzir um quadro semelhante ao de uma deficiência mental. Apesar de não estar na base da estrutura clínica daquela criança, essa deficiência se torna secundária a um encontro desastroso entre uma determinada criança, pais inábeis e uma antiescola.

Não é incomum encontrarmos jovens, de 12 a 14 anos, semianalfabetos e desprovidos dos recursos mínimos necessários para se relacionarem com situações que exijam uma capacidade de abstração e de análise. Para esses jovens, as coordenadas tempo-espaciais parecem ausentes. Eles desconhecem a organização do tempo no calendário, que um ano é dividido em 12 meses, quantos dias tem um mês, quanto dura uma semana. Não fazem ideia do lugar em que estão no mundo, qual a diferença entre país, estado, cidade.

Essa dificuldade de se situar no mundo, no tempo e no espaço é simbólica, produzindo limites reais. A indelével articulação entre saber e conhecimento faz das aprendizagens um processo que não diz respeito apenas à objetivação e à formalização de um conteúdo, mas também e, fundamentalmente, ao processo de subjetivação. Essas crianças chegam para o atendimento desencorajadas, desinteressadas, apáticas, e não expressam nenhum projeto futuro. A falta de balizas e de ancoragem produz uma insustentável leveza. Nesse contexto, proliferam-se os pensamentos místicos, para os quais os paradoxos são tolerados (ANZIEU, 2002). As crianças que não aprendem se assemelham, nesse aspecto, aos crentes: “o que é um mistério, para um crente, senão um paradoxo não resolvido? Os místicos obedecem a uma lógica rigorosa da não-resolução do paradoxo" (ibidem, p. 124).

Voltolini, em um ensaio sobre a aprendizagem em uma perspectiva psicanalítica (2006), afirmará que "a superação do mito pela razão só pode ser não-toda-feita" (ibidem, p. 
37). A tese defendida pelo autor nesse ensaio é a de que o conhecimento se presta mais a adaptar a realidade do mundo à realidade da fantasia do que ao inverso. No entanto, sabemos, quanto mais próximo da fantasia está o sujeito, mais distante ele estará do pacto social.

O "drama particular do sujeito" (ibidem, p. 38) afeta o modo como este responde ao chamado escolar para a objetivação, as aprendizagens e o compartilhamento. A fantasia é imperiosa em relação à realidade, mas não é capaz de aplacar a tensão entre as exigências de satisfação pulsional e as exigências de enquadre. Para responder a isso, o sujeito lança mão de uma "razão de conveniência" (ibidem) para a qual o paradoxal e o racional não comparecem como elementos excludentes ou incompatíveis, ao contrário, se fazem presentes no jogo psíquico em um "pacto de compromisso", cujo objetivo é evitar o desprazer.

Isso posto, entendemos não ser possível passar incólume por uma história escolar marcada pelo fracasso: os percalços vividos ao longo do percurso escolar produzem um impacto na vida subjetiva da criança no momento atual de sua infância, e deixam também marcas bastante difíceis de serem contornadas no futuro adulto ${ }^{50}$. Nesse sentido, no Trapézio, apoiar a escolarização é apoiar processos que participam do processo de subjetivação.

\subsection{Da estrutura da instituição}

\subsubsection{Da lógica das entrevistas preliminares}

O dispositivo de apoio à escolarização está estruturado de acordo com a lógica das entrevistas preliminares ${ }^{51}$ de uma análise, ou seja, suas intervenções estão a serviço do questionamento das certezas, da transformação da queixa inicial em enigma e da implicação do sujeito com sua questão.

\footnotetext{
${ }^{50}$ Um exemplo disso, dentro do âmbito pedagógico, é a diferença de se alfabetizar uma criança entre os 6 e 7 anos de idade e se alfabetizar um adulto: é muito mais difícil alfabetizar um sujeito que viveu a infância analfabeto.

${ }^{51}$ É preciso citar a dissertação de mestrado A escuta psicanalítica dos pais no tratamento institucional da criança psicótica, de Lina Galletti Martins de Oliveira (1998), como uma fonte inequívoca de inspiração para esta elaboração, que aproxima o tempo do tratamento no dispositivo institucional do Trapézio do tempo lógico das entrevistas preliminares.
} 
No caso da instituição, porém, todo o tratamento poderá se desenrolar dentro desse tempo (submetido à lógica das entrevistas preliminares), sem que uma demanda de análise seja formulada.

Em alguns casos, o final do tratamento coincidiu com uma virada discursiva, que permitiu à criança se reposicionar em relação à demanda escolar e às aprendizagens, bem como à formulação de um projeto para si, que foram suficientes para que a mesma prosseguisse sem a necessidade de uma análise. Em outras situações, o dispositivo mobilizou a criança ou um de seus pais, ou mesmo um professor, a ponto de ser formulada uma demanda de análise.

O objetivo do dispositivo institucional do Trapézio não é, como em uma análise, a travessia do fantasma. O tratamento na instituição visa a causar implicação com base em intervenções que pretendem produzir mudanças de posição discursivas, demovendo a criança do lugar discursivo de objeto e recuperando a implicação de todos no percurso escolar da mesma.

\subsubsection{Da ética da psicanálise}

Diverso das três abordagens do fracasso escolar expostas no capítulo três, o dispositivo institucional do Trapézio não focará um ponto de chegada. Apesar atender crianças e jovens que estão apresentando impasses em seu percurso escolar, tendo como baliza a ética da psicanálise, sustenta um olhar para além da queixa, visando a contextualizar e singularizar o não aprender em cada caso. Olhar para além da queixa implica uma subversão da expectativa ou demanda inicial, o que não quer dizer que esta não seja levada em consideração.Ela estará na pauta ao longo do tratamento, mas será desdobrada, fazendo com que o discurso sobre a criança prossiga e circule. Com isso, uma abertura é oferecida para que a criança ocupe, a seu modo, o seu atendimento.

Nunca é possível saber o ponto exato de chegada de uma dada intervenção, de uma fala, de uma aula, porque a experiência e a própria palavra são processadas de um modo absolutamente singular pelo sujeito que a escuta ou que a vive. Isso tem consequências para o lugar que ocupamos diante das crianças nas oficinas, que compõem o dispositivo de atendimento. Afirmamos ocupar o lugar de um educador atravessado pela psicanálise, o que implica dizer alguém capaz de escutar e de esperar, que tem notícias 
de seus limites e da barreira ética que se impõe entre nossa ação e as crianças com quem trabalhamos, e alguém com disposição para a surpresa e para o inusitado.

\subsubsection{Da triagem}

Este tempo do trabalho é dedicado a recolher e garimpar significantes "significativos" do caso, que embasem a elaboração de uma hipótese diagnóstica preliminar. Os instrumentos de leitura utilizados na construção dessa hipótese são a transferência e a escuta, pelos quais é possível fazer um esboço a respeito da posição da criança no laço, em relação ao Outro, e também em relação à fantasia parental. Mas se trata também de um tempo para intervir: "As primeiras intervenções, sejam com os pais ou com as crianças, já devem ser na direção de se desenrolar a única e fundante história que interessa: a história desejante" (MARTINS de OLIVEIRA, 1998, p. 57).

Diferente dos procedimentos clássicos de psicodiagnóstico, que avaliam para obter como resultado um quadro objetivo e definitivo a respeito do caso, a construção diagnóstica preliminar realizada na triagem do Trapézio é efeito do acolhimento inicial da transferência. Esta começa a produzir um efeito de saber, naquele que sustenta este lugar, e que irá oferecer elementos que deverão apoiar as decisões que serão tomadas, se a criança entrará (ou não) no programa e a direção do trabalho inicial. A triagem é o tempo para implicar os pais com as questões que os fizeram trazer o filho para atendimento, bem como para distinguir a queixa manifesta deles do sintoma da criança.

Costuma fazer parte dessa transferência inicial uma expectativa de que o atendimento vá recolocar a criança nos trilhos esperados das aprendizagens (KUPFER, 2000a). No entanto, o não aprender de cada sujeito, estando articulado a modos particulares de gozo, demandará mais do que ações de retificação.

O trabalho de apoio à escolarização do Trapézio visará a restabelecer as condições de escolarização de uma criança, permitindo que esta possa sustentar e suportar uma posição no laço social. Dentro do enquadre escolar, isso implica submetimento às demandas escolares, mas é importante que a criança encontre brechas para se incluir aí de um modo singular.

O profissional que conduz as entrevistas na triagem deve sustentar as demandas de saber dirigidas a ele, evitando o lugar do "especialista", daquele que detém a verdade 
sobre o outro. Essa posição, de sujeito suposto saber, própria ao campo da análise propriamente dita, é também condição para o estabelecimento da transferência no trabalho que se seguirá na instituição, e da formulação de uma demanda, na qual o próprio sujeito possa retomar uma questão sobre o que o trouxe para o atendimento.

As dificuldades que um sujeito pode vir a atravessar em seu processo de escolarização e em suas aprendizagens passam a ser objeto do tratamento oferecido pelo Trapézio na medida em que sejam identificadas uma demanda e um sofrimento (ou um mal-estar) que não puderam ser apaziguados por intervenções próprias ao campo educativo. $\mathrm{O}$ tratamento se ocupará disso que excede (o mal-estar) e com o qual escola e pais já não sabem como lidar.

Para finalizar, a decisão de receber ou não uma criança para atendimento será balizada pelo reconhecimento de um entrecruzamento das questões da criança, de seus pais e de sua escola, e da repetição da desimplicação.

\subsubsection{Do dispositivo de apoio à escolarização}

O dispositivo de atendimento articula intervenções dirigidas a três públicos: a criança, sua família e a escola. À criança são oferecidas oficinas, realizadas em grupos de até seis crianças; aos pais, entrevistas com o profissional de referência, e, aos professores, o trabalho de interlocução. A seguir, iremos descrever o funcionamento de cada um desses segmentos.

\subsubsection{As oficinas: $o$ trabalho em grupo, a dupla de coordenação, a produção e a escolha}

O Trapézio procura tornar superlativa a situação de encontro do sujeito com o objeto de conhecimento, na situação do laço social. Esse é o formato das oficinas que são oferecidas para as crianças, sempre mediadas pela realização de uma produção ${ }^{52}$, e que acontecem em pequenos grupos de até seis crianças. Nos grupos, os coordenadores ficam atentos ao modo como uma criança reage ao olhar do outro, se ficam inibidos,

\footnotetext{
${ }^{52}$ No início, no Trapézio, experimentamos a oferta de um grupo terapêutico cuja única mediação era a palavra, além é claro de alguns brinquedos e material plástico que ficavam à disposição das crianças. Entendemos que essa falta de contorno era um tanto angustiante para elas, que entravam em uma disputa fálica e se colocavam à margem das intervenções realizadas pelos coordenadores do grupo. Esse tipo de oferta também não contemplava o objetivo do dispositivo de intervir sobre situações de encontro com o objeto de conhecimento, na situação do laço, visando a uma mudança de posição em relação ao mesmo.
} 
agressivos, se paralisam ou se fingem que o outro não existe. Sabemos que o outro sempre interferirá em nosso aprender. Um outro que não é exatamente a criança que está ao lado, mas um Outro com o qual a criança se relaciona, que pode mais produzir embaraços do que ensejos. Nesses espaços, acontecem compartilhamentos de experiências, saberes e dúvidas.

A escolha de trabalhar em pequenos grupos não tem a intenção de otimizar o tempo de trabalho, atendendo mais crianças por hora, mas parte de um entendimento do grupo como ferramenta terapêutica. O grupo se revela um ambiente propício para a intervenção: em primeiro lugar, ele é bastante provocativo, no sentido da mobilização que ele gera. De algum modo, as crianças precisam responder a demandas, que muitas vezes não são formuladas diretamente pelos coordenadores das oficinas, mas sim pelo próprio grupo. Outro efeito muito interessante do grupo é o seu potencial para questionar certezas, para mexer com algumas posições cristalizadas das crianças; é comum que estas cheguem para o atendimento identificadas ao lugar de quem nada sabe, mas rapidamente o grupo proporcionará situações nas quais a criança se verá no lugar daquele que sabe. Esses movimentos, apesar de parecerem pequenos e singelos, podem, muitas vezes, ter o efeito de uma boa turbulência, capaz de fazer abalar certas certezas.

São esses aspectos que fazem do grupo uma ferramenta terapêtica, capaz de promover intervenções para além daquelas realizadas pelos coordenadores. Vemos o quanto a fala de uma criança endereçada a outra pode produzir um efeito mais direto e efetivo do que a fala de um dos coordenadores do grupo. Como exemplo disso, tem-se a repetida situação na qual uma criança tende a se refugiar à margem do grupo, esquivando-se dos convites e demandas que lhe são dirigidos. Nesse momento, quando uma outra criança do grupo se incomoda com isso e lhe chama, deixando claro o tanto que está incomodada de ter de fazer algo sozinha, ou de ver o outro supostamente sem fazer nada, esse chamado geralmente é bastante eficiente.

A mediação pela produção está presente em todas as oficinas. Temos hoje a oferta de uma Oficina de Linguagem, uma Roda de Leitura, um Ateliê de Artes e um Grupo de Projetos. Todas as atividades acabam, com frequência, utilizando-se da estratégia da elaboração de projetos na realização de suas produções. O projeto é uma forma de trabalho que requer, inicialmente, uma escolha, um posicionamento sobre o que será realizado, em seguida um pequeno planejamento de seus passos, a sustentação do 
investimento ao longo de sua execução e, finalmente, a conclusão. Sua duração é bastante variável, pode durar meses ou um encontro apenas. Quanto mais tempo dedicado a um projeto, mais os coordenadores dessa atividade deverão contribuir para que as crianças consigam sustentar essa produção a longo prazo. Isso se dará pela oferta de materiais, de sugestões ou de pesquisas realizadas com as crianças no intuito de oferecer repertório e consistência ao trabalho que estão realizando. Algumas vezes são programados passeios, visitas a museus ou entrevistas com esse objetivo.

Como se vê, os coordenadores das oficinas ocupam o lugar de educadores, que tanto estão atentos àquilo que vem das crianças, seus interesses e suas experiências, como também ofertam novas ideias. Estão no lugar de educadores, não de professores. As oficinas não são aulas, são espaços abertos à criação.

Muitas vezes, no entanto, este setting em aberto se revela opressor e angustiante para algumas crianças. Responder à pergunta “o que quer fazer?" é um pedido por demais exigente para crianças que chegam justamente identificadas com o lugar de quem nada sabe. Por isso, os coordenadores precisam saber dosar a espera e a oferta, o silêncio e a resposta, para não recaírem na angústia da impossibilidade de resposta por parte das crianças, ou na precipitação de uma oferta, que venha a se sobrepor à produção das mesmas, silenciando-as.

O fato de haver uma dupla de coordenação não tem o objetivo de para dar conta do número de crianças no grupo, mas sim inserir, no interior do funcionamento do grupo, o outro como baliza e como barra. Barra à extrapolação de limites em relação ao outro. Estamos sempre no risco de sermos capturados pela trama do outro, aproximando-nos por demais e, assim, afastando-nos da posição que nos permite olhar e escutar. Os coordenadores devem ocupar o lugar de uma nova versão de Outro, oferecendo-se enquanto sujeito barrado, como aquele que sabe um tanto, mas não sabe tudo. 


\subsubsection{O trabalho do profissional de referência: a escuta dos pais e a interlocução com a escola}

"Referência" é como chamamos o profissional da equipe responsável pela escuta dos pais, pela interlocução com a escola e por eventuais conversas individuais com as crianças. Esse profissional se ocupa tanto de fazer a mediação do caso com a instituição, controlando pagamentos, faltas, avisos etc., como também é quem se ocupa de alinhavar as várias situações que se apresentam no atendimento, colhendo significantes que circulam no discurso sobre a criança, organizando a história clínica de cada caso de modo a que este seja compartilhável na instituição, nas reuniões clínicas, nas supervisões e em seus relatórios.

O trabalho com os pais visa a ampliar as significações dadas ao sintoma do filho e implicá-los com essa questão. Nas conversas com os pais, a referência faz um convite a que estes falem sobre seu filho e avancem na questão que os trouxeram até a instituição. Muitas vezes, as famílias chegam ao Trapézio simplesmente porque foram encaminhadas, não estando apropriadas ou de acordo com as motivações que levaram a escola a indicar o atendimento para a criança. Nessas situações, a referência tem o papel fundamental de contribuir para que os pais se impliquem, se apropriem e signifiquem o atendimento. Em outras situações, encontramos o reverso dessa ausência de significação para o tratamento: é comum, no início do tratamento, depararmo-nos com algumas "certezas" no discurso parental sobre a criança que parecem ocupar o lugar de dar conta de toda a problemática do filho; a escuta dos pais está a serviço de dialetizar esse discurso fechado, permitindo que aconteçam desdobramentos e deslocamentos na posição da criança no discurso dos pais.

Importante fazer a ressalva de que, apesar de a direção do trabalho ser a da elaboração significante, não se trata de uma análise. Martins de Oliveira (1998) lembra a importância ética de "não se mistur(ar) na rede discursiva institucional, aquilo que é da ordem do pessoal e singular de cada pai” (ibidem, p. 157), afinal eles não chegaram à instituição em busca de tratamento para eles, mas sim para seus filhos. Se, porventura, uma demanda de análise se formular no decorrer do tratamento, esta deverá ser endereçada a um analista fora da instituição.

É a referência também quem realiza o trabalho que chamamos de interlocução com a escola, que também visa ao questionamento e à ampliação das significações conferidas 
ao aluno. Esse trabalho se encontra entre a recusa da orientação e a escuta da angústia do professor. Como, nesse trabalho, geralmente somos nós quem demandamos a conversa, não contamos com a demanda do professor, essencial para um trabalho pautado exclusivamente pela escuta. Quando vamos à escola conversar sobre uma criança, temos essencialmente o objetivo de questionar "certezas" e fazer abalar discursos fechados que embasam as conhecidas profecias autorrealizadoras.

Para tanto, precisamos muitas vezes conduzir a conversa com muita delicadeza e cuidado, afinal, trata-se de um atendimento e algumas situações que presenciamos nas oficinas do Trapézio permitem fazer o professor olhar para uma possibilidade daquele aluno até então não levada em consideração. Por exemplo, quando o professor diz que a criança não sabe ler e escrever e constatamos no atendimento que a criança está ingressando no letramento. Visamos também a uma implicação e ocupação do professor no processo de reflexão e elaboração de propostas que possam favorecer o aluno na sua relação com o aprender.

\section{Caso Teresa ${ }^{53}$ : da invenção de uma barreira simbólica para enfrentar a demanda do Outro}

Atendemos uma menina, então com 9 anos de idade, que estava cursando o $4^{\circ}$ ano do ensino fundamental, durante mais ou menos um ano e meio. Teresa chegou ao Trapézio encaminhada por sua escola, com uma queixa relacionada a dificuldades importantes na leitura e na escrita, identificada ao lugar do aluno copista ${ }^{54}$. Acima de tudo, chamava a atenção a forma como essa menina respondia a qualquer demanda vinda do outro: ficava paralisada, muda, com os olhos cheios de lágrimas, sem conseguir responder com nenhuma palavra ou de qualquer outro jeito. Isso acontecia na escola e se repetia nos grupos de atendimento do Trapézio.

O contexto do grupo é uma situação necessariamente provocativa, da qual é muito difícil sair ileso, intocado, não afetado pelo outro: a qualquer tempo, corre-se o risco de ser demandado a fazer, escutar, pensar, falar, a dar a ver ao outro sua observação, seu comentário, seu pensamento.

\footnotetext{
${ }^{53} \mathrm{O}$ nome da criança foi alterado.

${ }^{54}$ Vide nota 55.
} 
No início de seu tratamento, essas situações se revelavam um pedido por demais exigente para Teresa, por mais simples que pudessem ser as perguntas: "qual cor você prefere?", “onde você quer se sentar?". O outro com o qual ela se relacionava foi aos poucos se revelando um Outro bastante invasivo, excessivo e inadministrável.

Apesar desse enfrentamento com o outro não ser tarefa fácil de se administrar no grupo, este pode, ao mesmo tempo, promover algumas mudanças de forma ligeira, das quais as crianças podem ir se beneficiando desde o início do trabalho: por mais identificada que uma criança esteja com o lugar de quem nada sabe, por exemplo, são inúmeras as situações nas quais, na relação com o colega ao lado, é justamente ela quem sabe, promovendo uma mudança de posição, que independe de qualquer intervenção. Além disso, como as oficinas não têm um compromisso com um conteúdo a ser transmitido ${ }^{55}$, podem comparecer mais facilmente aí os interesses e o estilo de cada um.

A experiência desse encontro tão cuidado com o outro e com a produção foi permitindo aos poucos que Teresa se experimentasse, mesmo que timidamente no início, em lugares menos ameaçadores. São como ensaios, esboços de uma nova possibilidade.

Em uma atividade da Oficina de Linguagem, onde todos pesquisavam sobre a China (o disparador desse trabalho, na época, foram as Olimpíadas), Teresa se dedicou (além de participar da produção de todos) a fazer um livrinho à parte, com o título "As curiosidades da China" (que acabou se tornando o título do projeto), no qual ela registrou aquilo que da China mais lhe chamara a atenção: os telhados tão diferentes das casas, os ideogramas ${ }^{56}$ e as vestimentas das mulheres chinesas. Tratou-se de uma produção singela, uma capa com o título e seu nome, e três páginas, uma para cada tema de interesse, nas quais escolheu desenhar ${ }^{57}$ o tema em questão. Apesar da aparente simplicidade de sua produção, este é um exemplo de uma atividade na qual Teresa parecia estar confrontada a um outro menos invasivo, e já se notava aí sua capacidade

\footnotetext{
${ }^{55}$ Isso porque não se trata de aulas. As oficinas têm um objetivo de compartilhamento da cultura e de realização de produções que não são previamente escolhidas. Elas têm um formato de ateliês e convidam à criação.

${ }^{56}$ Interessante lembrar que se tratava de uma menina cuja dificuldade na aquisição da escrita passava por uma identificação com a imagem. Quanto mais apegada à imagem, mais distante a criança está da possibilidade de se alfabetizar. Fragelli (2011) aponta para a inflagem imaginária presente na escrita de algumas crianças que se revelam pouco disponíveis para o necessário percurso da alfabetização, que deve fazer cair o sentido da imagem em prol da significação do texto. Sua leitura clínica do fenômeno do "copismo" porta a hipótese de que a criança se imbui da tarefa de completar o Outro com o seu próprio corpo.

${ }^{57}$ Ela poderia ter feito uma colagem de recorte de revistas.
} 
de participar da cena do grupo e de se colocar com suas "curiosidades" e com seu estilo em um projeto coletivo.

Com o tempo ela foi se permitindo comparecer um pouco mais, respondendo, por vezes, um "não sei" bem baixinho, aproveitando os momentos que ninguém estava lhe demandando nada diretamente pra poder participar e fazer as coisas relacionadas aos projetos das oficinas.

Abro aqui um breve comentário a respeito do trabalho em questão para que se entenda que as situações prosaicas da instituição podem ser portadoras de perguntas extremamente exigentes e complexas do ponto de vista daquele a quem é demandado responder.

Estávamos no meio de um projeto escolhido pelo grupo que se chamava "Olhares sobre o Trapézio" ${ }^{\text {58 }}$. A proposta do projeto era usar a fotografia como estratégia para registrar depoimentos das crianças sobre a instituição. Para tanto, dedicamos alguns encontros à discussão sobre o Trapézio e sobre o que eles gostariam de transmitir, antes de pensar em qual imagem poderia traduzir melhor a intenção de cada um. Decididos o assunto e a imagem a ser registrada, fizemos um ensaio fotográfico em foto digital, e o expusemos para que as demais crianças e profissionais da instituição pudessem observar e comentar. Diante dos comentários recebidos, algumas crianças decidiram mudar a imagem, mas Teresa manteve sua escolha: fotografar a sala e a mesa de trabalho sobre a qual acontecia seu atendimento de fonoaudiologia. Teresa dava muito valor a esse atendimento: chegou a dizer que foi com sua fono que aprendeu a ler ${ }^{59}$. Confeccionamos câmaras escuras com caixas de sapato e, tendo conseguido o apoio de um laboratório de fotografia de uma galeria próxima à instituição, começamos a etapa de ensaios fotográficos em pin-hole ${ }^{60}$. Nessa etapa do projeto, as crianças experimentaram com igual intensidade a frustração da foto velada e a excitação dos primeiros traços gravados no papel fotográfico. Como se trata de um modo bastante rústico de fazer a foto, ele exige uma familiaridade com os elementos "intensidade da luz" e "tempo de exposição da câmara", coisa que só fomos ganhando aos poucos.

\footnotetext{
${ }^{58} \mathrm{O}$ tema do projeto foi escolhido pelo grupo.

${ }^{59}$ Na verdade, Teresa já lia e escrevia ao chegar ao Trapézio, mas como uma aluna "copista", completamente desimplicada do sentido de sua produção. Ao copiar, o sujeito se esquiva da submissão ao sistema alfabético e, no mesmo gesto, aceita o lugar imaginário de pura cópia do outro, de objeto (Fragelli, 2011).

${ }^{60}$ Pin-hole: uma câmara escura com um furo que funciona como "máquina fotográfica" de apenas uma imagem por vez.
} 
Curioso que a primeira foto mais ou menos bem-sucedida e a foto final com melhor resolução foi justamente "a mesa de trabalho" de Teresa. Como as fotografias foram "tiradas" sempre com o grupo todo presente e as decisões quanto ao melhor local de posicionar a caixa ou o tempo de exposição eram tomadas em conjunto, chegamos a pensar em coincidência, apesar de estarmos avisados de que quando estamos trabalhando sob o referencial psicanalítico essa ideia é ingênua ou incongruente. Importante marcar o quanto esse "feito" de Teresa chamou muito a atenção de todos, inclusive a dela ${ }^{61}$.

Voltando finalmente à pergunta que a ela dirigi, sobre qual título dar para sua fotografia, vê-se como toda resposta possível remontaria todo um percurso de trabalho, cheio de pequenas e preciosas histórias, lastreado por sua visível implicação.

Perante a questão que lhe é colocada, Teresa ficou alguns segundos em silêncio e então respondeu: "não sei ainda, posso pensar?".

Vejam só o que essa menina faz nesse instante: em primeiro lugar, ela responde "não sei ainda", o que é completamente diferente de dizer "não sei e ponto". Ela deixa em aberto a possibilidade de vir a saber. Além disso, ela pergunta: "Posso pensar?". Quer dizer, pede ao outro um tempo e uma distância imprescindível para que ela possa ficar mais tranquila, e para que possa pensar e, por fim, comparecer como sujeito.

Teresa criou uma nova possibilidade de resposta ao outro, que se revelou um recurso subjetivo fundamental para ela prosseguir. Vê-se como não se trataria aqui apenas de dar aula de reforço para essa menina. Havia algo, da ordem subjetiva, que a estava impedindo de caminhar em suas aprendizagens.

Sua fala "não sei ainda, posso pensar?" produziu-nos surpresa. Não que não esperássemos que ela pudesse mudar de posição em relação ao Outro; de certa forma, sempre esperamos que eles mudem de posição, mas "mudar de posição" é um modo genérico de nomear uma coisa que só pode acontecer de um modo absolutamente singular. Essa fala instituiu para essa menina uma barreira simbólica na relação com o Outro fundamental para que ela não se sentisse tão ameaçada e encontrasse uma forma possível de estar no laço, na relação com o outro.

\footnotetext{
${ }^{61}$ No ato da criação ocorre um drible do recalque, no qual o sujeito se sente surpreendido de alguma maneira. $\mathrm{O}$ que se produz nesse ato apresenta-se como uma novidade, como um achado.
} 


\section{Considerações finais}

Hannah Arendt afirmou que, enquanto houver homens sobre a Terra, eles só existirão de fato no plural e sua vida só será "boa" quando vivida com seus iguais. A educação é aquela que se encarrega de que os homens continuem sobre a Terra, no plural e em um mundo compartilhado. O fracasso da educação é uma ameaça direta ao plural dos homens e à possibilidade de compartilhamento.

Esta pesquisa se dedicou às particularidades dos impasses que hoje fazem pulular os obstáculos no campo educativo, rareando os seus ensejos. Também fez parte deste estudo a análise de uma instituição que se propõe a enfrentar esses impasses, oferecendo um dispositivo institucional de tratamento que dirige intervenções a crianças, pais e professores.

Ao longo desta dissertação, rastreamos o lastro dessas dificuldades, recuperando uma virada discursiva, ocorrida com o cogito de Descartes (vide seção 4.1., O discurso da ciência como A verdade, do capítulo I). Em "A ciência e a verdade", Lacan reconstituiu a origem do discurso da ciência, que, articulando a técnica à ilusão de completude, forjou um a-sujeito ${ }^{62}$ e instituiu, no âmago do laço social, uma disposição totalitária e segregatória.

Apegado a uma posição de gozo, esse sujeito se oferece como instrumento do outro, renunciando à posição de desejo em prol da estabilidade oferecida pela fixidez do lugar de objeto. A dessubjetivação conduz, a um só tempo, a um apaziguamento da angústia e à desimplicação, caracterizada por uma anestesia (mórbida) do pulsar do desejo.

Segundo o psicanalista C. Melman (como vimos no capítulo II), o objeto de consumo paradigmático na contemporaneidade é a droga, porque esta é o objeto que melhor traduz aquilo que os homens de hoje almejam: uma saturação completa, a saciedade plena, o apaziguamento irrestrito. É por isso que esse autor considerou a drogadição um sintoma social, porque o modo de gozar do toxicômano é paradigmático do modo de gozar do sujeito contemporâneo.

Da mesma forma, entendemos que os impasses escolares metaforizam uma verdade da civilização contemporânea: sob a égide dos discursos do capitalista e da ciência, se

\footnotetext{
${ }^{62} \mathrm{O}$ a-sujeito é o sujeito que "se demitiu de sua posição de sujeito porque se demitiu de sua faculdade de julgar [...] um sujeito que se demite de sua enunciação e se contenta em ser congruente com os enunciados aos quais consentiu em se sujeitar" (LEBRUN, 2004, p. 72).
} 
tornou imperiosa a ilusão de completude, o que produz um empuxo ao gozo. A suturação da falta e o apagamento dos limites estão no cerne da subversão proposta por esses discursos. Assim como o toxicômano realiza o sonho de todo neurótico de apaziguar sua dor de existir, defendemos, nesta dissertação, a tese de que o não aprender da criança realiza o sonho neurótico de subversão dos limites e de negação da castração.

Esta pesquisa permitiu a construção dos seguintes argumentos para embasar a proposição de que os impasses escolares são um sintoma social:

1. a pregnância e insistência, no plano discursivo, dos problemas escolares;

2. uma imbricação discursiva produzida pelo encontro de um discurso totalitário, avesso ao desejo, com um sujeito neurótico ávido por nada deixar a desejar;

3. a referência a um modo de organização libidinal, observada nos impasses escolares, que apontam para um modo de funcionamento social.

Tais argumentos embasam a afirmação de que os impasses escolares metaforizam uma verdade da civilização. Estes produzem um desaparelhamento da educação; sem desejo e sem implicação, esta perde suas condições de possibilidade. O discurso hegemônico da pedagogia porta uma disposição totalitária que aspira ao controle absoluto dos acontecimentos. É verdade que todo discurso pedagógico visa à mestria, não importando sua filiação teórica ou ideológica. A pedagogia sempre será uma prática que buscará equipar-se da melhor forma para se aproximar o máximo possível da direção esperada em relação às crianças e suas aprendizagens. Mas sua aliança com o discurso tecnocientífico, e o abandono de seu aporte filosófico, lançou-a direto à ilusão de que é possível deter um controle absoluto sobre os acontecimentos em uma sala de aula. E, no âmbito da instituição escolar, tal ilusão incide de modo a fazer supor, em todo aquele que escape ao ideal suposto de aprendizagem, uma patologia.

Tal situação vem produzindo um excesso de encaminhamentos de alunos com supostos transtornos e de prescrições medicamentosas, que, de nosso ponto de vista, atendem mais às expectativas de contenção e controle do que as terapêuticas. 
Outro fator importante é a insistente preocupação psicopedagógica de conhecer mais $e$ mais a criança, o que supostamente traria "embasamento" científico para sua ação, garantindo assim uma intervenção assertiva. "Saber mais sobre a criança", no entanto, tem se revelado uma falácia: quanto mais o professor sabe sobre a criança, menos pode operar na relação com ela como educador. O saber do professor que interessa é aquele que se dirige ao objeto de conhecimento que ele escolheu transmitir. O educador não visa à criança, ele visa ao mundo compartilhado, visa à inserção da criança no mundo, porque seu compromisso é com o bem público.

No encontro com esse contexto, muitos sujeitos (crianças, pais e professores) têm respondido com seus sintomas. E a tendência da instituição escolar tem sido responder a eles com uma exigência de suspensão. Para a psicanálise, entretanto, o sintoma é uma manifestação subjetiva: lá onde há sintoma, há sujeito (QUINET, 2006). Trata-se de uma construção laboriosa que este forja para dar conta da sua relação com o Outro. Para o sintoma, nos diria Freud, não há solução, mas há, sim, dissolução, ou seja, desdobramentos. Não se trata, portanto, de suspendê-los ou eliminá-los, mas sim de escutá-los e manejá-los.

Foi com o intuito de oferecer uma outra resposta aos impasses escolares que o Trapézio fez a sua invenção. Esta instituição pretende incluir o sujeito e seu sintoma, de modo a recuperar sua implicação, entendendo que esta é uma condição imprescindível aos processos de aprendizagem e de subjetivação.

A contribuição da psicanálise, nesse cenário, é a de oferecer o seu testemunho, que aponta justamente para o avesso dessa posição. O controle almejado não é exequível, e isso não por uma impotência ou por algum tipo de deficiência, mas por uma impossibilidade estrutural.

Não se trata apenas - como afirmou Calligaris na apresentação dos intentos do grupo "Sexto Lobo", no livro Clínica do social (1991a) - de "constituir uma doutrina psicanalítica sobre o sintoma social" (p. 13), tampouco de "uma promessa de consertos ou pacificação" (ibidem). O impossível, sabemos, não tem conserto. Trata-se, sim, de "inventar uma prática discursiva no social" (ibidem) capaz de expor as contradições que animam o socius, produzindo pequenos abalos nos alicerces rígidos que estruturam os discursos sociais, visando a fazer frente à tendência que os discursos têm de se tornarem hegemônicos. 
Para finalizar, gostaríamos de apontar para pelo menos dois caminhos diferentes de prosseguimento desta pesquisa, que se revelaram ao seu final. Um deles diz respeito ao estudo diferencial dos sintomas que comparecem nas aprendizagens; o outro, aos fatores contingentes que atravessam e sobredeterminam o contexto estrutural ao qual nos dedicamos nesta pesquisa. 


\section{REFERÊNCIAS BIBLIOGRÁFICAS}

ADORNO, Theodor W. Educação e emancipação. Rio de Janeiro: Paz e Terra, 1995.

AGAMBEN, Giorgio. Homo Sacer: o poder soberano e a vida nua I. Belo Horizonte: Editora UFMG, 2002.

ANZIEU, Didier. O pensar: do eu-pele ao eu-pensante. São Paulo: Casa do Psicólogo, 2002.

ARAGÃO, Luiz Tarlei (et al.) Clínica do social: ensaios. São Paulo: Escuta, 1991.

ARENDT, Hannah. A crise na educação. In: Entre o passado e o futuro. São Paulo: Perspectiva, 1997.

ASKOFARÉ, Sidi. O sintoma social. In: Goza! Capitalismo, globalização e psicanálise. Ricardo Goldenberg (org). Salvador, BA: Ágalma, 1997.

ARIÈS, Philippe. História social da criança e da família. Rio de Janeiro: Editora Guanabara, 1981.

BARONE, Leda. Considerações a respeito do estabelecimento da ética do psicopedagogo. In: SCOZ, Beatriz (et al.), Psicopedagogia - o caráter interdisciplinar na formação e atuação profissional. Porto Alegre: Artes Médicas, 1987.

BARROS, Manuel de. O livro das ignorãças. Rio de Janeiro: Record, 2004.

BERNARDINO, Leda Maria Fischer. De uma instituição a uma prática possível efeitos de um (bom) encontro. In: Revista Estilos da Clínica, n. 4, ano III, $1^{\circ}$ semestre, 1998.

BLEICHMAR, Hugo. O narcisismo: estudo sobre a enunciação e a gramática inconsciente. Porto Alegre: Artes Médicas, 1985.

CALLIGARIS, Contardo. Prefácio (O Porquê de um nome). In: ARAGÃO, Luiz Tarlei (org). Clínica do social: ensaios. São Paulo: Escuta, 1991a. 
Paulo: Escuta, 1991b.

A sedução totalitária. In: Clínica do social: ensaios. São . Hello Brasil: notas de um psicanalista europeu viajando pelo Brasil. São Paulo: Escuta, 1992.

. Três conselhos para a educação das crianças. In: Educa-se uma criança? Porto Alegre: Artes e Ofícios, 1994, pp. 25-30.

CAMUS, Albert. A queda. São Paulo: Círculo do Livro, sem data.

CANGUILHEM, Georges. O que é a psicologia? In: Estudos de história e de filosofia das ciências: concernentes aos vivos e à vida. Rio de Janeiro: Forense, 2012.

CHARLOT, Bernard. Relação com o saber, formação dos professores e globalização: questões para a educação hoje. Porto Alegre: Artmed, 2005.

COUTINHO JORGE, Marco Antonio. Discurso e liame social: apontamentos sobre a teoria lacaniana dos quatro discursos. In: RINALDI, Doris e COUTINHO JORGE, Marco Antonio (orgs). Saber, verdade e gozo. Leituras de O Seminário, Livro 17, de Jacques Lacan — Rio de Janeiro: Rios Ambiciosos, 2002.

DI CIACCIA, Antonio. Inventar a psicanálise na instituição. In: Pertinências da psicanálise aplicada. Rio de Janeiro: Forense Universitária, 2007.

DOR, Joël. Introdução à leitura de Lacan: o inconsciente estruturado como linguagem. Porto Alegre: Artes Médicas, 1989.

ENDO, Paulo César. Disciplina de mestrado: O sujeito, a política e a psicanálise. IPUSP, 2009.

FINK, Bruce. Psicanálise e ciência. In: O sujeito lacaniano: entre a linguagem e o gozo. Rio de Janeiro: Jorge Zahar, 1998, pp. 170 - 179.

Ciência e Psicanálise. In: Para ler o seminário 11 de Lacan: os quatro conceitos fundamentais da psicanálise. Rio de Janeiro: Jorge Zahar Editora, 1997. 
FOUCAULT, Michel. Doença mental e psicologia. Rio de Janeiro: Tempo Brasileiro, 1988.

FRAGELLI, Ilana Katz Z. A alfabe(s)tização: perspectivas da articulação sujeito e escrita. Tese de Doutorado, Faculdade de Educação - USP, 2011.

FREIRE, Ana Beatriz et al. (orgs.) A ciência e a verdade: um comentário. Rio de Janeiro: Revinter, 1996.

FREIRE COSTA, Jurandir. Narcisismo em tempos sombrios. In: Tempo do desejo. Sociologia e Psicanálise. São Paulo: Brasiliense, 1991.

Aula: Da vida política à vida higiênico-romântica: percurso da subjetividade na cultura do Ocidente. CPFL, 2008.

FREUD, Sigmund. (1908) Moral sexual civilizada e doença nervosa moderna. In: Edição Standard Brasileira das obras psicológicas completas de Sigmund Freud, vol IX. Rio de Janeiro: Imago, 1980.

. (1914) Errinern, Wiederholen und Durcharbeiten. In: Schriften zur Behandlungstechnik. Frankfurt am Main: S. Fischer, 1975.

. (1913) Totem e Tabu. In: Edição Standard Brasileira das obras psicológicas completas de Sigmund Freud, vol XIII. Rio de Janeiro: Imago, 1980.

(1917) Uma dificuldade da psicanálise. In: Edição Standard Brasileira das obras psicológicas completas de Sigmund Freud, vol. XVII. Rio de Janeiro: Imago, 1980.

. (1919a) O estranho. In: Edição Standard Brasileira das obras completas de Sigmund Freud, Vol. XVIII, pp. 273-318. Rio de Janeiro: Imago, 1976.

. (1919b) Das Unheimliche. In: Die Freud-Sudienausgabe Band IV: Psychologischen Schriften. Frankfurt am Main: Fischer Taschenbuch Verlag, 1982.

. (1925) Prefácio à juventude desorientada. In: Edição Standard Brasileira das obras completas de Sigmund Freud, vol. XIX. Rio de Janeiro: Imago, 1976. 
. (1930) O mal-estar na civilização. In: Edição Standard Brasileira das obras completas de Sigmund Freud, vol. XXI. Rio de Janeiro: Imago, 1976.

. (1933) Conferência XXXV: A questão de uma Weltanschauung. In: Edição Standard Brasileira das obras completas de Sigmund Freud, vol. XXII. Rio de Janeiro: Imago, 1976.

. (1937) Análise terminável ou interminável. In: Edição Standard Brasileira das obras completas de Sigmund Freud, vol. XXIII. Rio de Janeiro: Imago, 1976.

HOUAISS, Antonio. Dicionário eletrônico da Língua Portuguesa. Objetiva, 2002.

JERUSALINSKY, Alfredo. O sujeito infantil e a infância do sujeito. In: Revista Estilos da Clínica. São Paulo, IPUSP, n. 4, pp. 146 - 159, 1998.

KOLTAI, Caterina. Política e psicanálise. O Estrangeiro. São Paulo: Escuta, 2000.

KUPFER, M. C. Freud e a educação, dez anos depois. In: In: Revista da Associação Psicanalítica de Porto Alegre, n. 16, Porto Alegre: APPOA, pp. 14-26, 1995.

2000a.

Educação para o futuro: psicanálise e educação. São Paulo: Escuta,

A psicanálise na clínica da infância: o enfrentamento do educativo. In: A Psicanálise e os Impasses da Educação. São Paulo: Lugar de Vida: LEPSI, pp. 96 a 103, 2000b.

. O que toca à/a psicologia escolar? In: Psicologia escolar: em busca de novos rumos. São Paulo: Casa do Psicólogo, 2004.

LACAN, Jacques. (1969-1970) O Seminário, Livro 17: o avesso da psicanálise. Rio de Janeiro: Jorge Zahar, 1992.

. (1965) A ciência e a verdade. In: Escritos. Rio de Janeiro: Jorge Zahar, 1998, pp. 869 a 892. 
LAJONQUIÈRE, Leandro de. De Piaget a Freud: para repensar as aprendizagens. A (psico)pedagogia entre o conhecimento e o saber. Petrópolis, RJ: Vozes, 1992.

Freud, e educação e as ilusões (psico)pedagógicas. In: Revista da Associação Psicanalítica de Porto Alegre, n. 16, Porto Alegre: APPOA, pp. 27-38, 1995.

. A psicanálise, a educação e a escola de Bonneuil. A (À) lembrança de Maud Mannoni. In: Estilos da Clínica, n.4, 1998.

. Freud e a educação. In: A Psicanálise e os Impasses da Educação. São Paulo: Lugar de Vida: LEPSI, p. 96-103, 2000.

Infância e ilusão (psico)pedagógica. Escritos de Psicanálise e educação. Petrópolis, RJ: Vozes, 2009.

Figuras do infantil: a psicanálise na vida cotidiana com crianças. Petrópolis, RJ: Vozes, 2010a.

e educação. FEUSP, 2010b.

. Disciplina de mestrado: Tópicos especiais de psicanálise

LAURENT, Eric. O gozo do débil. In: A criança no discurso analítico. Rio de Janeiro: Jorge Zahar, 1991.

A sociedade do sintoma: a psicanálise, hoje. Rio de Janeiro: Contra Capa Livraria, 2007a.

Dois aspectos da torção entre sintoma e instituição. In: Pertinências da psicanálise aplicada. Rio de Janeiro: Forense Universitária, 2007b.

LEBRUN, Jean-Pierre. O mundo sem limites: ensaio para uma clínica psicanalítica do social. Rio de Janeiro: Companhia de Freud, 2004, pp. 51-96.

LEOPOLDO e SILVA, Franklin. Descartes: a metafísica da modernidade. São Paulo, Moderna, 2005.

LIMONGI, Maria Isabel. Hobbes. Rio de Janeiro: Jorge Zahar Ed., 2002. 
MARTINS DE OLIVEIRA, Lina Galletti. A escuta psicanalítica dos pais no tratamento institucional da criança psicótica. Dissertação de mestrado. São Paulo: Instituto de Psicologia da USP, 1998.

MANNONI, Maud. Educação impossível. Rio de Janeiro: Francisco Alves, 1988.

MELMAN, Charles. Alcoolismo, delinquência e toxicomania: uma outra forma de gozar. São Paulo, Escuta, 1992.

MILLER, Jaques-Alain e MILNER, Jean-Claude. Você quer mesmo ser avaliado? Entrevistas sobre uma máquina de impostura. Barueri, SP: Manole, 2006.

MILLOT, Catherine. Freud antipedagogo. Rio de Janeiro: Jorge Zahar, 1992.

MUSIL, Robert. O homem sem qualidades. Rio de Janeiro: Nova Fronteira, 1989.

NAJLES, Ana Ruth. Problemas de Aprendizaje y Psicoanálisis. Buenos Aires: Grama Ediciones, 2008.

PATTO, Maria Helena Souza. Psicologia e ideologia: uma introdução crítica à psicologia escolar. São Paulo: T.A. Queiroz, 1984.

O conceito de cotidianidade em Agnes Heller e a pesquisa em educação. In: Perspectivas, São Paulo, 16, pp. 119-141, 1993.

A produção do fracasso escolar: histórias de submissão e rebeldia. São Paulo: Casa do Psicólogo, 1999.

Prefácio. In: Psicologia Escolar: em busca de novos rumos. São Paulo: Casa do Psicólogo, 2004.

PEREIRA, Antonio Luiz. Seminários de resolução de problemas: problemas matemáticos: caracterização, importância e estratégias de resolução. Instituto de Matemática da $\quad 2002$ USP, Recuperado de http://www.ime.usp.br/ trodrigo/documentos/mat450/mat450-2001242-seminario-8resolucao_problemas.pdf, em 10 de julho de 2011. 
PETRI, Renata. Psicanálise e educação no tratamento da psicose infantil: quatro experiências institucionais. São Paulo: Annablume/FAPESP, 2003.

. Psicanálise e infância: clínica com crianças. Rio de Janeiro/São Paulo:

Companhia de Freud/FAPESP, 2008.

QUINET, Antonio. Psicose e laço social. Rio de Janeiro: Jorge Zahar, 2006.

A ciência psiquiátrica nos discursos da contemporaneidade. Recuperado de http://www.estadosgerais.org/historia/161-a_ciencia.shtml, em 15 de março de 2011.

ROUDINESCO, Elizabeth. Por que a psicanálise? Rio de Janeiro, Jorge Zahar Ed., 2000.

RUBINSTEIN, Edith. A psicopedagogia e a associação estadual de psicopedagogos de São Paulo. In: SCOZ, Beatriz et al., Psicopedagogia - o caráter interdisciplinar na formação e atuação profissional. Porto Alegre: Artes Médicas, 1987.

SANTIAGO, Ana Lydia. A inibição intelectual em psicanálise. Rio de Janeiro: Jorge Zahar, 2005.

SAVIANI, Dermeval. Escola e democracia. Campinas, SP: Autores Associados, 2001.

SCOZ, Beatriz. Psicopedagogia e realidade escolar. Petrópolis, RJ: Vozes, 1994.

STEVENS, Alexandre. A instituição: prática do ato. In: Pertinências da psicanálise aplicada. Rio de Janeiro: Forense Universitária, 2007.

SOUZA LEITE, Marcio Peter. Ensaio sobre a psicanálise e o social. Recuperado de http://www.marciopeter.com.br/links2/ensaios/ensaios_lacanmarx.html , em 20 de junho de 2008.

VOLTOLINI, Rinaldo. Educação e psicanálise. Rio de Janeiro: Zahar, 2011.

Disciplina de mestrado: Educação e psicanálise. FEUSP, 2010. 
Pensar é desejar. In: Revista Educação Especial: Biblioteca do professor, n1, Freud pensa a educação. São Paulo, Ed. Segmento, pp. 36-45, ago, 2006.

. Psicanalisar e educar ou psicanálise e educação? Um retorno a Freud. Recuperado de http://www.educacaoonline.pro.br, em 20 de setembro de 2009.

Video, 2010 (DVD).

. Pensadores e a educação: Jacques Lacan. São Paulo: Nittas

VORCARO, Ângela. Seria a toxicomania um sintoma social? In: Mental, Revista da saúde mental e subjetividade da UNIPAC, nov, vol II, n. 3, Barbacena, pp. 61 -73, 2004.

VORCARO, Ângela e VERAS, Viviane. O saber entre a recusa e a impotência. In: $A$ psicanálise e o trabalho com a criança-sujeito: no avesso do especialista. Recuperado de http://pt.wikipedia.org/wiki/Analfabetismo_funcional, em 20 de abril de 2012. 